DOI: $10.17242 / M V v K \_30.05$

\title{
VÍZIMADÁR FAJOK ÁLLOMÁNYVISZONYAI A BALATON DÉLI PARTJÁN 2003-2008 KÖZÖTT
}

\author{
POPULATION DYNAMICS OF WATERBIRD SPECIES ON THE SOUTHERN SHORE \\ OF LAKE BALATON BETWEEN 2003-2008
}

\author{
Kovács Gyula \\ Soproni Egyetem, Vadgazdálkodási és Gerinces Állattani Intézet \\ University of Sopron, Institute of Wildlife Management and Vertebrate Zoology \\ H-9400 Sopron, Bajcsy-Zs. u. 4., Hungary, e-mail: delbalaton@gmail.com \\ MME Dél-Balatoni Helyi Csoport \\ BirdLife Hungary South-Balaton Local Group \\ H-8638 Balatonlelle, Irmapuszta, Hungary
}

\section{BEVEZETÉS}

A Balaton madárvilágának szakirodalma igen terjedelmes, bár többnyire nem volt rendszeres, szisztematikus felmérés. A vízimadárállomány hosszú távú monitorozása csak néhány évtizede működik hazánkban, így a Balatonon is. Jelen dolgozatban az Magyar Madártani és Természetvédelmi Egyesület Dél-Balatoni Helyi Csoport első öt éves felméréseinek eredményét közlöm. Az alábbiakban összefoglaltam a Balatonon végzett korábbi hasonló léptékü felméréseket.

$\mathrm{Az}$ első átfogó, a tó madárvilágát részletesen bemutató tudományos mű LoVASSY SÁNDOR nevéhez füződik. A 74 fajt bemutató dolgozat A Balaton tudományos tanulmányozásának eredményei 2. kötetében (LOVASSY, 1897) jelent meg.

Az előzőekhez hasonlóan a tihanyi kutatóintézet kiadványában jelent meg HOMONNAY (1940) a Balaton és környékének madarairól szóló, 50 év eredményeit összefoglaló munkája. A 256 megfigyelt fajból, 134 költő madarat említ, hangsúlyozva, hogy további fajok előfordulása is lehetséges, illetve a jövőben várható. Megállapítása szerint „a fajgazdagság nincsen arányban a madárnépességgel”. „Bőség csak bizonyos időszakban és az is csak egyes igen kedvező élettereken észlelhető." Tudománytörténeti szempontból érdemes megemlíteni, hogy bár igen jelentős a Balatonról szóló addig összegyült ornitológiai irodalom, „tervszerü megfigyelések nem végeztettek".

A Magyar Biológiai Kutatóintézet megbízásából KEVE ANDRÁs (akkor még KLEINER ENDRE), PÁTKAI IMRE és VERTSE ALBERT, a Madártani Intézet tisztviselői 1941-ben egy egész éves megfigyelés sorozatot hajtottak végre (KLEINER et al., 1942). Itt a mindennapos felmérés volt a cél, nem pedig a minél nagyobb terület felmérése, ezért megfigyeléseik javarészt a Tihanyi-félszigetre szorítkoztak, a Balaton többi területeit ritkábban látogatták. Munkájukat több más megfigyelök (CSÖRgey TITUS, KELlER OSZKÁR, MÁRY GYULA, SiKÓ SZILÁRD, SZALAY LAJOS ElEMÉR, KLASZ IVÁN, LOVASSY SÁNDOR) adataival egészítették ki, az így elkészült terjedelmes jelentés 201 fajt tartalmazott.

A vízimadarakra Balatonon is alkalmazott szinkron rendszerű vizsgálatok eredményeiről KEVE \& SCHMIDT (1963) írt.

A Balaton madártani irodalmában figyelemre méltó KEVE (1968) Aythynae és Merginae-fajok előfordulásáról és vonulásuk évi ciklusairól szóló alapos dolgozata. A tó kutatásáról szóló cikkek, nemcsak a hazai, hanem a külföldi tudományos közönség érdeklődését is felkeltették, melynek folyományaként 1968. május 15-19. között rendezték meg a 
Nemzetközi Madárvédelmi Bizottság európai szakosztályának IX. konferenciáját Balatonszemesen (ANONYM, 1970).

Az 1970-es években KEVE folytatta a Balaton vízimadarairól szóló, nagyobb rendszertani egységekben taglalt cikksorozatát. Az úszórécékről (KEVE, 1970a) végzett megfigyeléseit a korábbi irodalmi adatok ismertetésével kiegészítve dolgozta fel. Az egyes fajok állománydinamikáját grafikonokon is ábrázolta, előfordulásukat, fenológiájukat enciklopédikus alapossággal írta le. Ugyanígy feldolgozta a limikolák (KEVE, 1970b), a guvatfélék (KEVE, 1972a), a sirályok (KEVE, 1972b), a búvár- és vöcsökfajok csoportját, a gödényt és a kárókatonát (KEVE, 1973) is.

KEVE a tỏle megszokott részletességgel áttekintést adott a Balaton déli partjának (1975, 1978) madárvilágáról. A vízimadarak rendszeres számlálása ebben az időszakban kezd gyakorlattá válni az országban, ezek összesített - egyben a balatoni adatokat is tartalmazó eredményeit a tőkés- és a csörgő réce szempontjából SCHMIDT (1974, 1976), a vonuló libák tekintetében STERBETZ (1975) foglalta össze.

KEVE után a Balaton vonuló és telelő vízimadár állománybecslését BANKOVICS (1985) végezte el. Munkájában a három éves kutatás során az eddigiektől eltérően, hajóról, a part mentén a víz felől számolta a tavon tartózkodó vízimadarakat. Az adatokat partról végzett megfigyelésekkel egészítette ki. A vizsgálatok az egész Balatonra vonatkoztak, így a tó kiterjedése miatt egy teljes felmérés két napig tartott. A 71 megfigyelt fajból 20 énekes madár volt, illetve több ritka faj is elökerült.

1994-ben megalakult a Dél-Balatoni Természetvédelmi Csoport (az MME 35-ös számú helyi csoportja), ami új lendületet adott a Balaton madártani kutatásának. HAVRANEK LÁszLó nyugdíjas középiskolai tanár vezetésével a csoport tagjai rendszeres felméréseket végeztek a Balatonon és a déli parti vizes élőhelyeken, melyekről a négy számot megért, saját kiadású ANSER nevü folyóiratban számoltak be. Az 1991-1994-es időszak balatoni madárvonulásairól részletes tanulmányt HAVRANEK et al. (1995), majd az aktuális időszakról HAVRANEK (1995; 1996a) közölt. Külön a ludakról közel három évtizedes adatokat feldolgozva HAVRANEK (1996b) írt. Jelentős faunisztikai jellegű összegző munka HAVRANEK \& SzABÓ (1997) A Balaton és környéke madárfaunájának indexe. Az 1995 év végével bezárólag három évtized adatait bemutató, a Balatonra és a déli parti területekre vonatkozó checklist, 219 fajt tartalmaz, státuszuk megjelölésével.

1984-től a Magyar Vadlúd Monitoring, 1996-tól a Magyar Vízivad Monitoring felmérései keretében szezononként nyomon követhetök a Kis-Balaton, a Keszthelyi-öböl és a Balaton keleti részének (Szántód-Zamárdi környéke) vízimadár állományviszonyai (FARAGÓ, 1996; 1998a; 1998b; 1999a; 1999b; FARAGÓ \& JÁNOSKA, 1996a; 1996b). A Nyugatmagyarországi Egyetem Vadgazdálkodási és Gerinces Állattani Intézete a Magyar Vízivad Közleményekben folyamatosan adta közre a balatoni vízimadár adatokat (FARAGÓ, 2001a; 2001b; 2002a; 2002b; 2002c; 2005a; 2005b; 2006a; 2006b; 2007a; 2007b; 2007c; 2007d; 2008a; 2008b; 2010a; 2010b; 2010c; 2010d; FARAGÓ \& GOSZTONYI 2002; 2003a; 2003b).

Az MME Dél-Balatoni Helyi Csoportja 2003-ban kezdte a Balaton déli partjának rendszeres, havonkénti madártani monitorozását, melyről KovÁCs (2005a; 2005b; 2007a; 2007b; 2008a; 2008b) számolt be. A csoport 2005-től minden évben a teljes Balatonra és a környező vizes élőhelyekre kiterjedő vonuló és telelő vízimadárállomány-felmérést szervez (KovÁCs 2008c; 2008d, 2008e). Egész éves teljes felmérést a Balaton-felvidéki Nemzeti Park munkatársai (NAGY et al. 2008) is végeznek 2003 augusztusától, nyáron havi, egyéb időszakokban kétheti rendszerességgel. 


\section{ANYAG ÉS MÓDSZER}

\subsection{Terepi adatgyüjtés}

A terepi felmérés a nemzetközi (KAUPINNEN et al., 1991; KOSKIMIES \& PÖYSÄ, 1991) és a hazai (FARAGÓ, 1997) gyakorlatban is alkalmazott felmérési módszereket alapján történt. A monitoringot az MME Dél-Balatoni Helyi Csoportja szervezi, a szerző irányításával. A megfigyeléseket havonta egyszer, hóközepén végeztük a Balaton déli partján, 18 kijelölt partszakaszon (1. térkép). Egyidejűleg három, lehetőség szerint több fös csapatban mértük fel a területet, egymással szinkronban. A megfigyelésekhez $8 \times 30$-as, 10×50-es kézi távcsöveket, illetve 20-60-szoros nagyítású spektíveket használtunk. Az egyedszám megállapítása számlálással történt, a becslést lehetőség szerint kerültük. A számlálásokat az ajánlásoknak megfelelően délelőtt végeztük. Jelen munkában 5 év, 60 szinkronnap, 1048 megfigyelés (megfigyelési egység) adatait dolgoztam fel. A megfigyelések dátumai: 2003.03.01., 03.15., 04.13., 05.17., 06.14., 07.12., 08.16., 09.13., 10.18., 11.15., 12.13.; 2004.01.17., 02.14., 03.14., 04.17., 05.15., 06.12., 07.17., 08.15., 09.18., 10.16., 11.19., 12.18.; 2005.01.15., 02.12., 03.13., 04.16., 05.14., 06.18., 07.16., 08.13., 09.16., 10.14., 11.12., 12.23.; 2006.01.14., 02.18., 03.18., 04.15., 05.14., 06.15., 07.15., 08.12., 09.16., 10.14., 11.25., 12.16.; 2007.01.13., 02.17., 03.17., 04.14., 05.12., 06.17., 07.14., 08.18., 09.15., 10.13., 11.10., 12.15.; 2008.01.13. A felmérésben részt vettek (*a rendszeres megfigyelök): BAJOR ZOLTÁN, *BENDE ZsOLT,

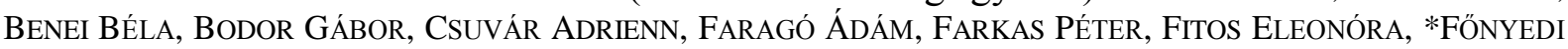

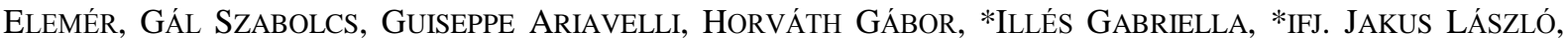

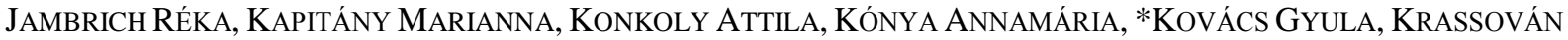
KriszTina, *Lelovics András, Mészáros András, MÉszáros Tibor, MÉszárosné M. JÚlia, Molnár

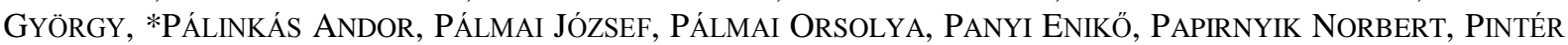

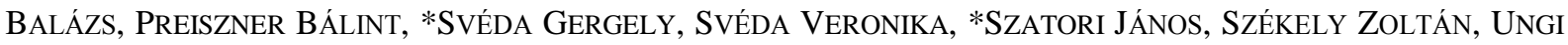
BALÁzs, VerseCZKi Nikoletta, *ifJ. VinCZE BÉla, Zsoldos CSABA.

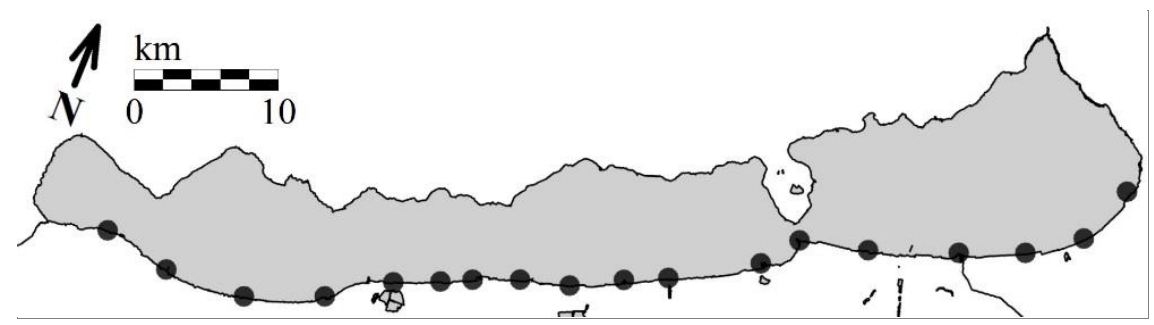

1. Térkép: Megfigyelési pontok a Balaton déli partján

Map 1: Observation points on the southern shore of Lake Balaton

\subsection{Adatfeldolgozás és kiértékelés}

A nevezéktan alapja az aktuális magyar névjegyzék (MME NoMENCLATOR BizOTTSÁG, 2008). A sztyeppi sirály (Larus cachinnans) és sárgalábú sirály (Larus michahellis) adatait összevontant elemeztem, mivel a terepi felmérések során sem különítettük el. (Meg kell jegyezni, hogy bár a taxonómiai szétválasztás már általánosan alkalmazott a terepmadarászok körében, az elkülönítés nagyobb távolságokban, kedvezötlen látási viszonyok között, illetve fiatal egyedek esetén nem egyszerü feladat.)

Az előfordulási gyakoriság alapján az 5\% feletti frekvenciájú fajokat gyakorinak, az 1\% felettieket (+ rétisas, jégmadár) szórványosnak, a többit pedig ritkának minősítettem.

A gyakori fajok állományának nagyságrendi (ezres, százas, tízes) meghatározásához az éves maximumok átlagát vettem alapul.

A kiértékelés során fajok állománynagyságát az átlag és maximum értékek alapján állapítottam meg. Az egyes szezonok adatsorai átlagok alapján történő összehasonlítására egyváltozós varianciaanalizist (one-way ANOVA) alkalmaztam, az egyes évek páronkénti 
összehasonlítására (post-hoc) Tukey HSD-tesztet használtam, $p<0,05$ szignifikanciaszint mellett.

Az állományváltozást, a populációváltozás (chain) indexszel (GREENWOOD et al., 1993) vizsgáltam (az egyes évek átlagos egyedszámának egymáshoz való viszonya). A bázisév (100\%) a 2003-2004-es szezon volt. Az egyes évek átlagaiból a populációváltozás index alapján lineáris regresszióval határoztam meg az állományváltozási trendet (slope). A trend erősségét a determinációs koefficiens $\left(r^{2}\right)$ fejezi ki, a szignifikanciáját F-próbával ellenőriztem. A trend meghatározása az EBCC módszertanán alapul (PANNEKOEK \& VAN STRIEN, 2001), ahol az éves változás mértékét figyelembe véve:

- erős növekedés/csökkenés: a változás jelentősen meghaladja az 5\%-ot és szignifikáns,

- mérsékelt növekedés/csökkenés: a változás nem haladja meg jelentősen az 5\%-ot és szignifikáns,

- stabil: az állomány nem csökken/növekszik (<1\%) és szignifikáns,

- bizonytalan: nem állapítható meg változás.

Az adatfeldolgozáshoz Microsoft Excel 2010, PAST v.2.12 (HAMMER et al., 2001) programokat használtam.

\section{EREDMÉNYEK}

A szinkronnapokon megfigyelt madarak közül összesen 10 rend, 16 család, 86 faját sorolom fel. Ebbe beletartozik a fehér gólya (Ciconia ciconia), a ragadozók (Accipitriformes, Falconiformes) és a jégmadár (Alcedo atthis) is, amelyek nem tartoznak szorosan a vízimadárfaunába, de fontosnak tartottam közlésüket. A vízimadarak közül 7 rend, 12 család, 78 faja fordult elö. A fajok közül gyakorinak 16-ot, szórványosnak szintén 18-at, a többit pedig ritkának minősítettem.

\subsection{Gyakori vízimadárfajok állományviszonyai}

Bütykös hattyú (Cygnus olor)

Az állományváltozás tekintetében egyértelmü trendről nem beszélhetünk, mindamellett az egyes évek között az állománynagyságban jelentős ingadozást tapasztaltunk (73,7-209,2 pld). A második évre erőteljes növekedés (Tukey HSD $\mathrm{Q}=6,22 ; \mathrm{p}=0,0001$ ), majd egy év múlva ennél is nagyobb csökkenés (Tukey HSD $\mathrm{Q}=7,05 ; \mathrm{p}<0,0001$ ), utána mérsékeltebb növekedés volt tapasztalható (Tukey HSD Q=2,57; 1,22; $\mathrm{p}=0,37 ; 0,91$ ). A bázisévhez képest az állomány, a második év kivételével, a többiben nem tért el szignifikánsan (1., 2. ábra, 6. táblázat).

Évközi állománya a februári minimumot (átlag 15,4 pld) követően folyamatos növekedést mutatott a szeptemberi állománycsúcsig (átlag 256,8 pld), majd a csökkenés januárra a tavaszi szintet érte el (5. ábra).

Nyári lúd (Anser anser)

A térségben fészkelő nyári lúd állomány, de ugyanígy a nagy mennyiségü vonuló és telelő liba csapatok a vizsgált dél-balatoni partszakaszokon nem túl gyakran, illetve nem nagy számban jelentek meg. Az öt évre vetítve az állományváltozás trendje statisztikailag nem igazolható, a változások sem a bázisévhez képest, sem egymáshoz viszonyítva nem szignifikánsak (4. ábra, 6. táblázat).

Főként ősszel és télen jelent meg a Balatonon, bár ekkor sem volt gyakori. Februártól augusztusig mindössze csak 47 pld-t figyeltünk meg szórványosan (0-16 pld). Május, június és 
szeptember hónapokban egyáltalán nem láttuk (6. ábra). Legtöbb egyedet januárban figyeltük meg, igaz az egyes évek között igen nagy eltérés volt (0-619 pld) (3. ábra).

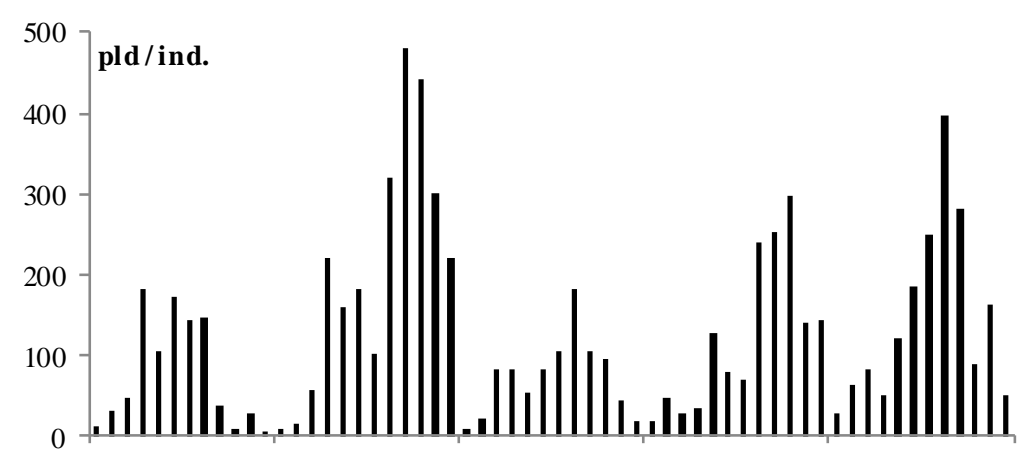

1. ábra: Bütykös hattyú egyedszám a Balaton déli partján az egyes megfigyelési napokon (2003-2008)

Figure 1: Number of Mute Swans on the southern shore of Lake Balaton, on the observations (2003-2008)

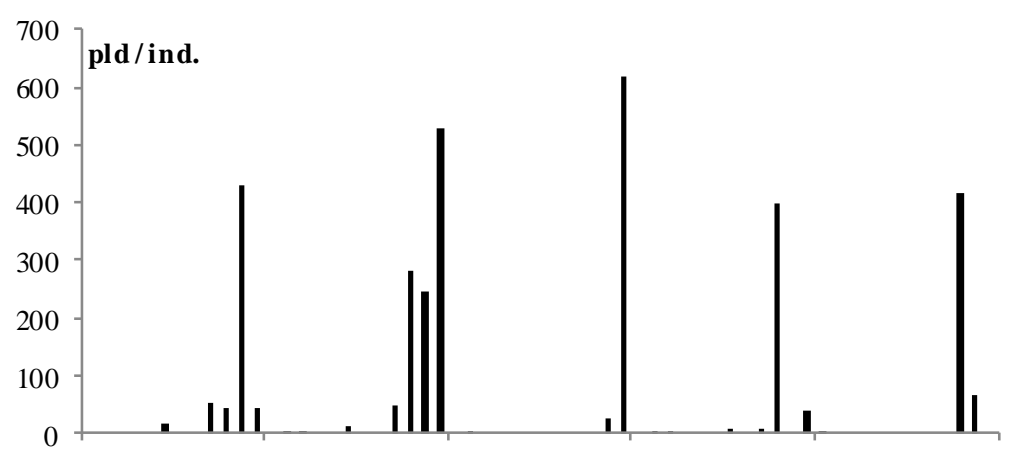

3. ábra: Nyári lúd egyedszám a Balaton déli partján az egyes megfigyelési napokon (2003-2008)

Figure 3: Number of Greylag Geese on the southern shore of

Lake Balaton, on the observation days (2003-2008)

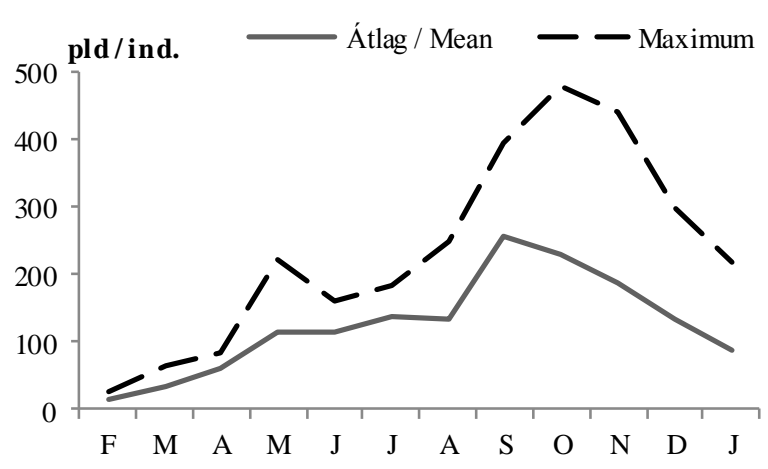

5. ábra: Bütykös hattyú havi átlagos állománynagysága és maximuma a Balaton déli partján (2003-2008)

Figure 5: Monthly average and maximum population of Mute Swan on the southern shore of Lake Balaton (2003-2008)

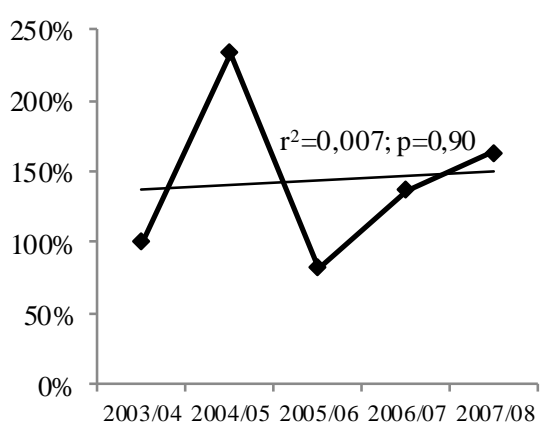

2. ábra: A bütykös hattyú populációváltozás indexe

Figure 2: Population index change of Mute Swan

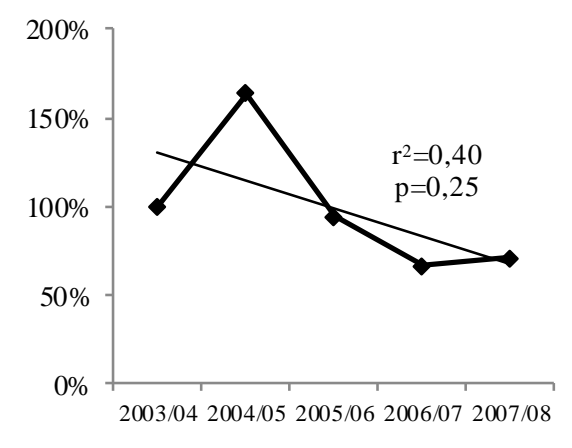

4. ábra: A nyári lúd populációváltozás indexe Figure 4: Population index change of Greylag Goose

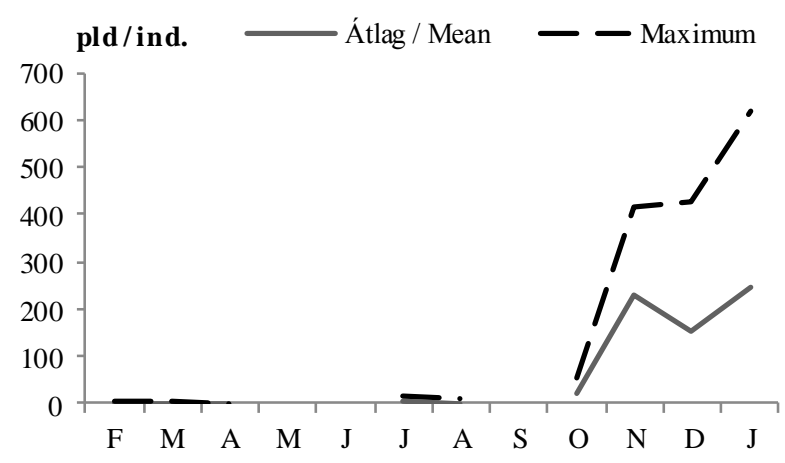

6. ábra: Nyári lúd havi átlagos állománynagysága és maximuma a Balaton déli partján (2003-2008)

Figure 6: Monthly average and maximum population of Greylag Goose on the southern shore of Lake Balaton (2003-2008) 
Tőkés réce (Anas platyrhynchos)

A Balaton leggyakoribb és domináns faja számára a terület igen jelentős vonuló- és telelőhely, továbbá a többi déli parti vizes élőhellyel együtt fontos költőterület is. Az állomány a harmadik évig folyamatosan csökkent, majd a kezdetihez képest a felére emelkedett (7., 8. ábra). A változás lineáris összefüggéssel nem írható le pontosan, másodfokú függvénnyel közelíthető megfelelően $\left(r^{2}=0,96 ; p=0,04\right)$. Valamennyi szezon állománya szignifikánsan kisebb volt az elsőhöz képest (6. táblázat).

Kora tavasszal a februári $\sim 840$ pld-os átlagos állománynagyság márciusra majd a felére csökken ( 440 pld). A legkisebb számban áprilisban fordult elő, átlagosan 74,4 pld. Ezután folyamatos állománynövekedést tapasztaltunk, augusztusra elérte az 1000 pld feletti állománynagyságot, a csúcsot pedig decemberben, átlagosan 2781,8 pld-t. Jellemző, hogy a legzordabb téli időkben sem tünik el, amikor a Balaton befagy (január, február). Ilyenkor a madarak állandó mozgása által fennmaradó kis felületü lihogókban koncentrálódnak néhány más faj (barátréce, kerceréce) társaságában (11. ábra).

Kanalas réce (Anas clypeata)

Az öt év alatt az állomány kevesebb, mint felére csökkent, mindazonáltal a második és harmadik szezon közötti változáson (Tukey HSD Q=3,95; $\mathrm{p}=0,04$ ) kívül más viszonylatban szignifikáns különbséget nem lehetett kimutatni (9., 10. ábra, 6. táblázat).

Áprilisban és szeptembertől decemberig fordult elö, ősszel a leggyakoribb. A legtöbbet októberben figyeltük meg, átlagos állománynagysága ebben a hónapban 83,8 pld volt (12. ábra).

\section{Barátréce (Aythya ferina)}

Vonuló- és telelőállománya igen jelentős a Balatonon. A költőállományuk szintén számottevő a térségben, de ezek a halastavakon és berkekben fészkelnek. A második szezonban tapasztalt tömeges megjelenés - mint kiugróérték (14. ábra folytonos vonal) - nélkül állománynövekedés volt tapasztalható (szaggatott vonal), amely azonban nem bizonyult szignifikánsnak. Az átlagos állománynagyság sem egymáshoz, sem a bázisévhez képest nem különbözött szignifikánsan (6. táblázat, 13. ábra).

Az év minden hónapjában jelen volt, októbertől márciusig tömegesen. A márciusi csúcs (átlagos állomány 754,0 pld) valamivel magasabb, mint a novemberi (647,6 pld), amikor előfordulása a leggyakoribb. A tőkés récéhez hasonlóan a leghidegebb téli időkben is megfigyelhetö (17. ábra).

\section{Kontyos réce (Aythya fuligula)}

Bár az átlagok alapján az állományváltozás látványosnak tünik, valójában a kevés nagyszámú előfordulások torzítják a populációváltozás indexét (15., 16. ábra), így az egyes szezonok között nem mutatható ki szignifikáns különbség (6. táblázat).

Szeptembertől márciusig fordult elő, márciusi (átlagos állomány 253,6 pld) és novemberi (230,8 pld) csúcsokkal, amikor az állomány többszöröse volt a többi hónaphoz képest (18. ábra).

\section{Kerceréce (Bucephala clangula)}

Az átlagos állománynagyság statisztikailag hasonló volt mindegyik évben (6. táblázat), és egyértelmủ állományváltozási trend sem volt kimutatható (19., 20. ábra), állománya stagnáló.

Május-július között egyáltalán nem fordult elő, augusztus és szeptemberben egy-egy példány, októberben két alkalommal. A tömeges megjelenés novembertől márciusig volt jellemző (23. ábra), ebben az időszakban gyakori. Hasonlóan a barátrécéhez és tőkés récéhez 
a Balaton befagyásakor sem tünik el. Legnagyobb számban január hónapban volt jelen (átlagállomány 1657,0 pld), de egész télen és kora tavasszal átlagos állománya jóval meghaladta a 800 pld-t.

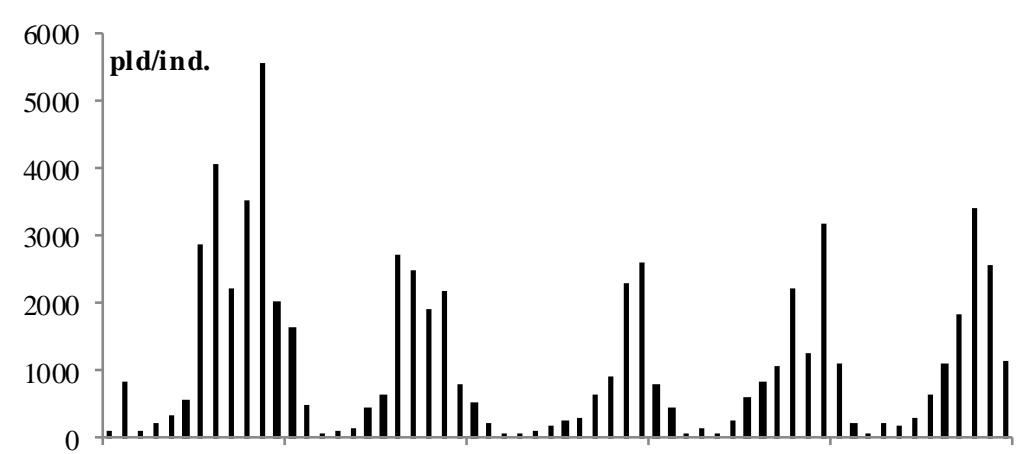

7. ábra: Tőkés réce egyedszám a Balaton déli partján az egyes megfigyelési napokon (2003-2008)

Figure 7: Number of Mallards on the southern shore of Lake Balaton, on the observation days (2003-2008)

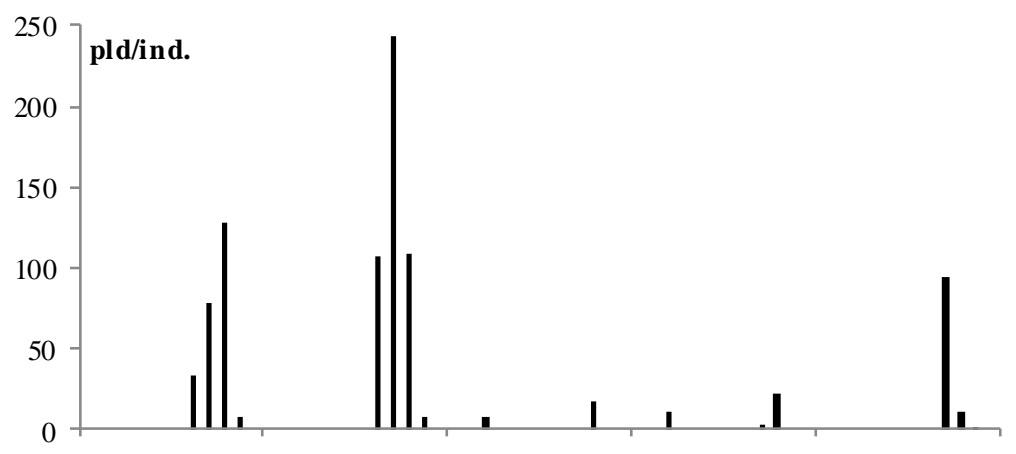

9. ábra: Kanalas réce egyedszám a Balaton déli partján az egyes megfigyelési napokon (2003-2008)

Figure 9: Number of Northern Shovelers on the southern shore of Lake Balaton, on the observation days (2003-2008)

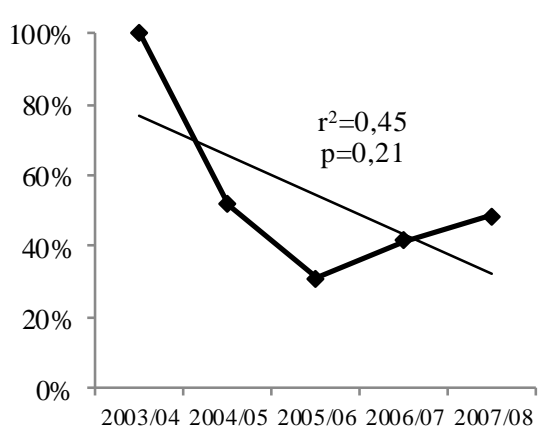

8. ábra: A tőkés réce populációváltozás indexe Figure 8: Population index change of Mallard

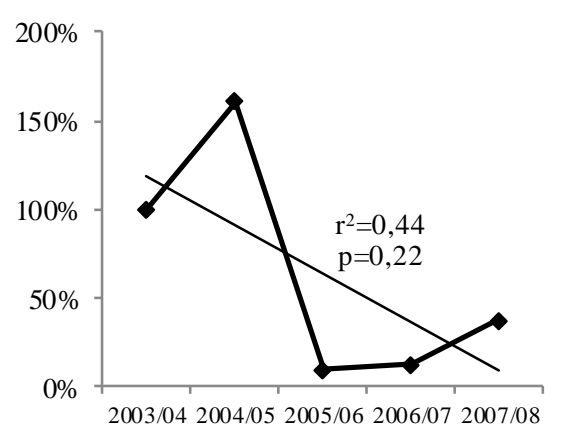

10. ábra: A kanalas réce populációváltozás indexe Figure 10: Population index change of Northern Shoveler

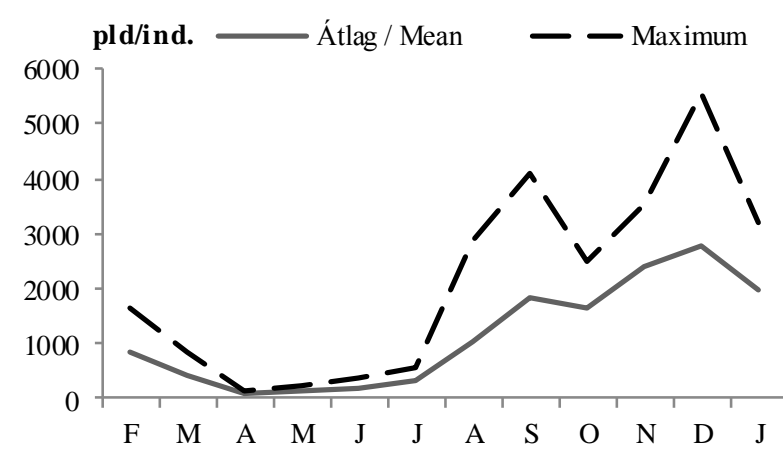

11. ábra: Tőkés réce havi átlagos állománynagysága és maximuma a Balaton déli partján (2003-2008)

Figure 11: Monthly average and maximum population of Mallard on the southern shore of Lake Balaton (2003-2008)

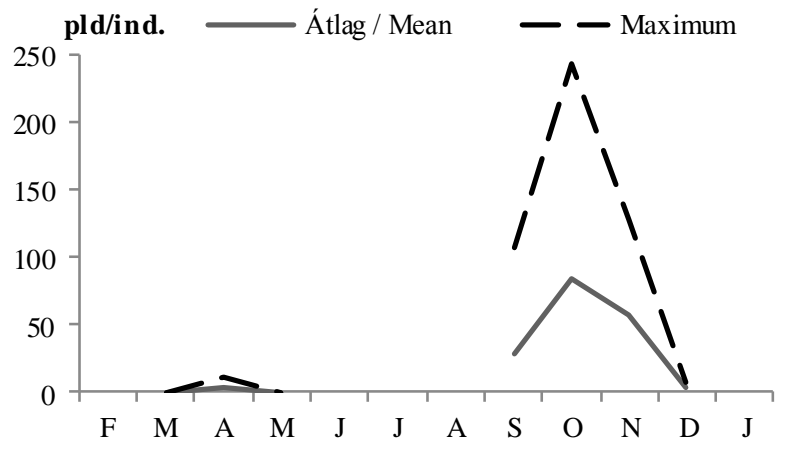

12. ábra: Kanalas réce havi átlagos állománynagysága és maximuma a Balaton déli partján (2003-2008)

Figure 12: Monthly average and maximum population of Northern Shoveler on the southern shore of Lake Balaton (2003-2008) 


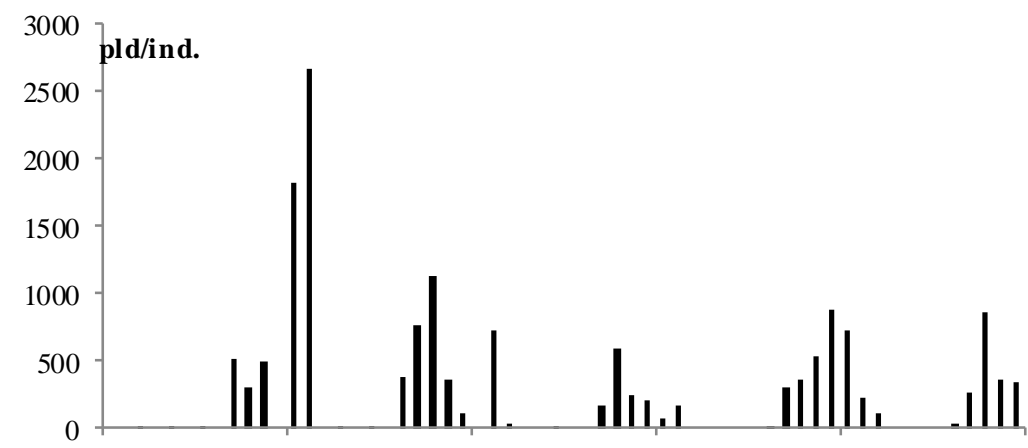

13. ábra: Barátréce egyedszám a Balaton déli partján az egyes megfigyelési napokon (2003-2008)

Figure 13: Number of Pochards on the southern shore of Lake Balaton, on the observation days (2003-2008)

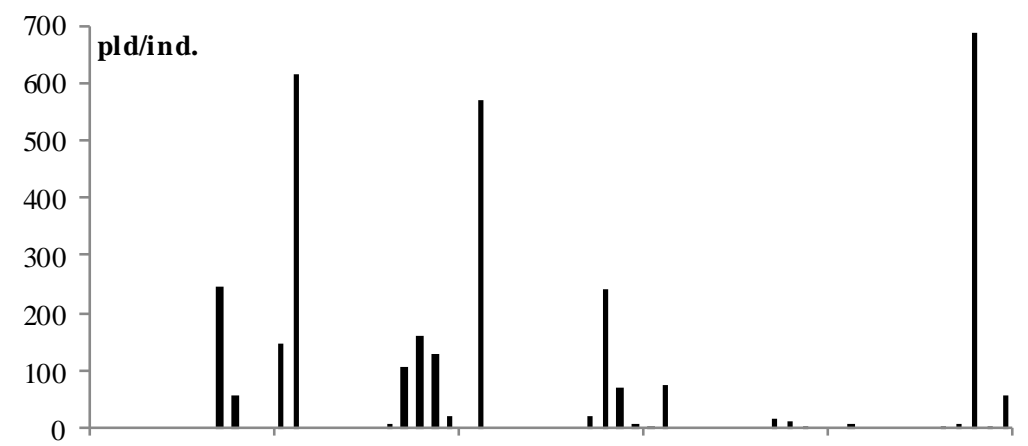

15. ábra: Kontyos réce egyedszám a Balaton déli partján az egyes megfigyelési napokon (2003-2008)

Figure 15: Number of Tufted Ducks on the southern shore of Lake Balaton, on the observation days (2003-2008)

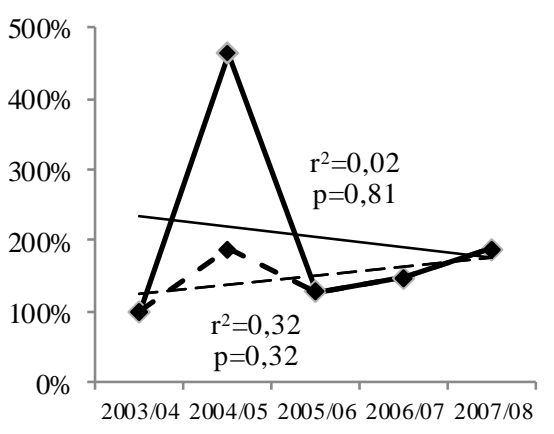

14. ábra: A barátréce populációváltozás indexe Figure 14: Population index change of Pochard

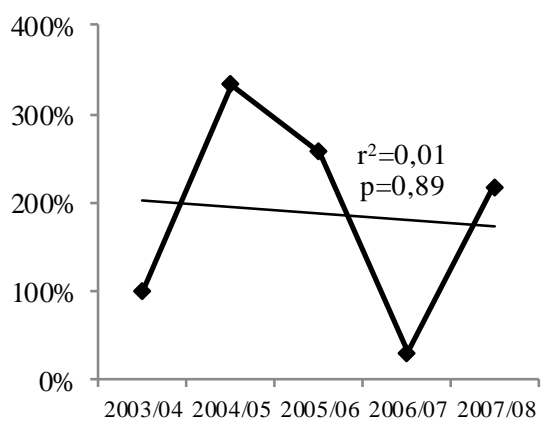

16. ábra: A kontyos réce populációváltozás indexe Figure 16: Population index change of Tufted Duck

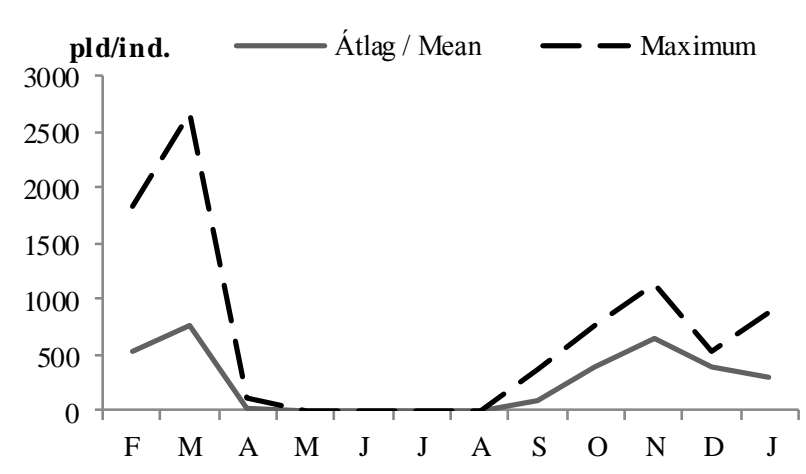

17. ábra: Barátréce havi átlagos állománynagysága és maximuma a Balaton déli partján (2003-2008)

Figure 17: Monthly average and maximum population of Pochard on the southern shore of Lake Balaton (2003-2008)

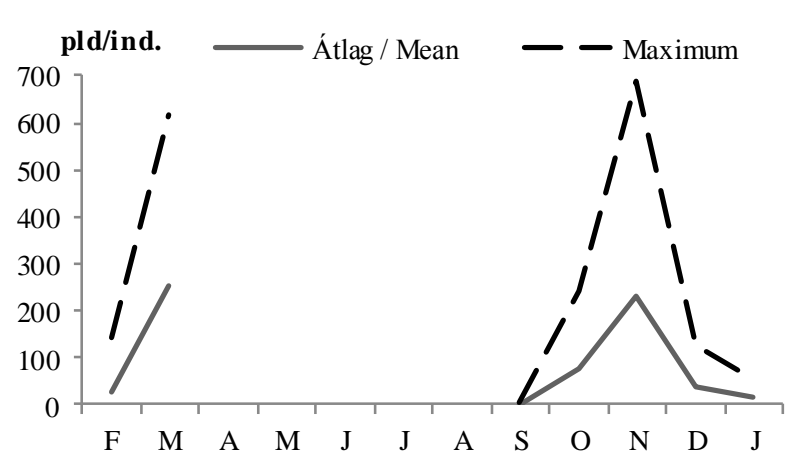

18. ábra: Kontyos réce havi átlagos állománynagysága és maximuma a Balaton déli partján (2003-2008)

Figure 18: Monthly average and maximum population of Tufted Duck on the southern shore of Lake Balaton (2003-2008) 


\section{Búbos vöcsök (Podiceps cristatus)}

Az öt év alatt az egyes megfigyelési napokon igen nagy fluktuációt mutatott (0-265 pld) (21. ábra). A populációváltozás index alapján dinamikus növekedés látható, ahol a második kivételével valamennyi szezon szignifikánsan eltért a bázisévhez képest (22. ábra, 6. táblázat).

A tavaszi és őszi állománycsúcsok során az előfordulás gyakorisága is nagyobb volt, mint az év többi időszakában. Februárban fordult elö a legkisebb számban, az első három évben 0-0 pld, átlagosan 7,6 pld az egész déli parton. Az egyedszáma és gyakorisága egyaránt áprilisban volt a legnagyobb (átlagos állománynagyság 110,6 pld) (24. ábra).

\section{Kárókatona (Phalacrocorax carbo)}

Az állomány változása még a kiugróan magas érték elhagyásával (szaggatott vonal) is csak gyenge szignifikanciát mutatott (26. ábra). A trend növekedő jellegét a két utolsó téli kiugróan magas csoportosulás okozta, mely azonban nem tekinthető állandó állománynak. Az egyes évek összehasonlításban nem volt szignifikáns különbség (25. ábra, 6. táblázat).

A legnagyobb mennyiségben decemberben gyültek össze, a kumulált egyedszáma közel 7000 pld, az átlagos állománynagyság ebben a hónapban 1397,8 pld volt. Májustól szeptemberig állománya az évi átlag harmadára-felére csökkent, a minimum augusztusban volt (átlagban 43,4 pld). Jellemzően novembertől februárig tartó időszakban volt gyakori (29. ábra).

\section{Kis kócsag (Egretta garzetta)}

Az állományváltozásban csökkenő tendenciát tapasztaltunk, ugyanakkor az összefüggés nem bizonyult szignifikánsnak (28. ábra). Az első évhez képest mindegyik szezonban az állomány szignifikánsan kisebb volt. 2003-2004-hez képest az állomány a harmadik évben a tizedére csökkent, de az ötödik évben is csupán a $28 \%$-a volt (29. ábra, 6. táblázat).

Áprilistól októberig figyeltük meg, bár volt olyan év (2005), amikor csak júliusban és augusztusban jelent meg (30. ábra).

\section{Nagy kócsag (Egretta alba)}

A kis kócsaghoz hasonlóan állománycsökkenést tapasztaltunk, gyenge összefüggés és alacsony valószínűség mellett. A populációváltozás index a harmadik szezonig a tizedére esett vissza, majd mérsékelten emelkedett a bázisévhez képest a harmadára. Az első és második szezon közötti különbségen kívül a többi szignifikáns volt (31., 32. ábra, 6. táblázat).

Február és december kivételével valamennyi hónapban előfordult, nagyobb számban azonban májustól szeptemberig (átlagos állománynagyság $\geq 14,0$ pld). A legnagyobb számban szeptemberben volt jelen (átlagosan 22,2 pld), a legkevesebb januárban 1, illetve novemberben 2 példány, mindkét eset 2004-ben volt (35. ábra). Júniusban volt a leggyakoribb.

\section{Szárcsa (Fulica atra)}

Az állományváltozást tekintve növekedésről lehet beszélni, ahol a második évben kiemelkedően magas értékeket számoltunk (33. ábra, 6. táblázat). Ez a kiugró érték a bázisévhez képest jelentősen különbözött (Tukey HSD Q=4,34; $\mathrm{p}=0,02$ ), ezért emellett a determinációs együttható nem utal erős kapcsolatra (34. ábra folytonos vonal). Ugyanakkor a kiugró értékek elhagyásával igen erős viszonyt feltételez a koefficiens értéke (szaggatott vonal).

Július kivételével minden hónapban megfigyelhetö volt. A 400 pld feletti átlagos állománynagyság szeptembertől januárig volt jellemző, 1600 egyednél több pedig októberben és novemberben, a maximum októberben (1708,2 pld) (36. ábra). Gyakoriságára is nagyjából az egyedszámmal megegyező tendenciák jellemzők. 


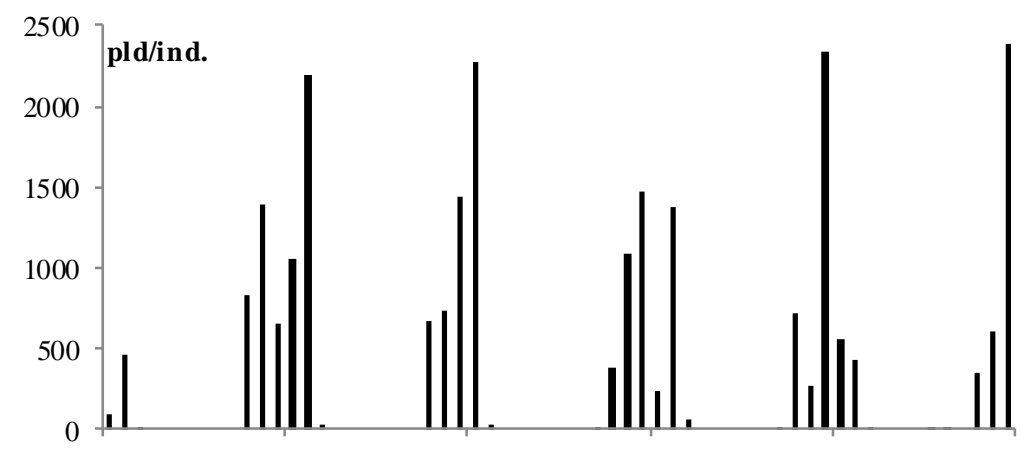

19. ábra: Kerceréce egyedszám a Balaton déli partján az egyes megfigyelési napokon (2003-2008)

Figure 19: Number of Goldeneyes on the southern shore of Lake Balaton, on the observation days (2003-2008)

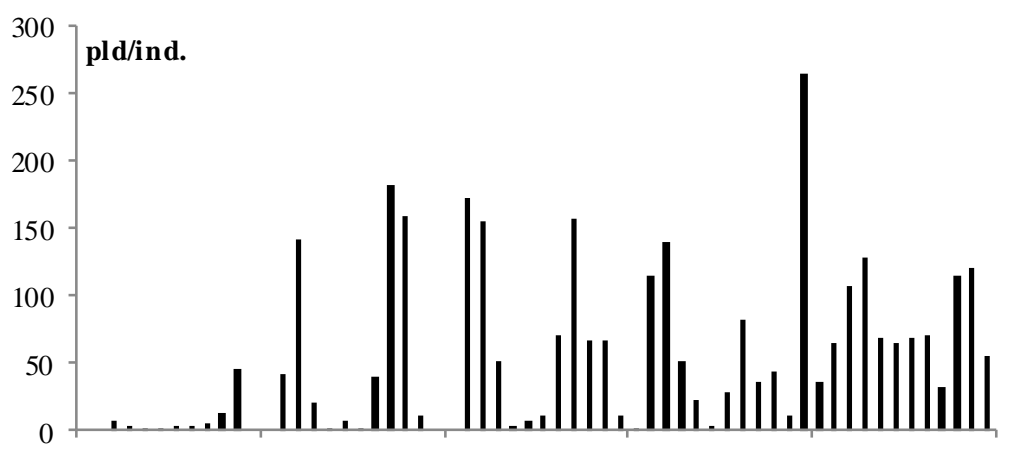

21. ábra: Búbos vöcsök egyedszám a Balaton déli partján az egyes megfigyelési napokon (2003-2008)

Figure 21: Number of Great Crested Grebes on the southern shore of Lake Balaton, on the observation days (2003-2008)

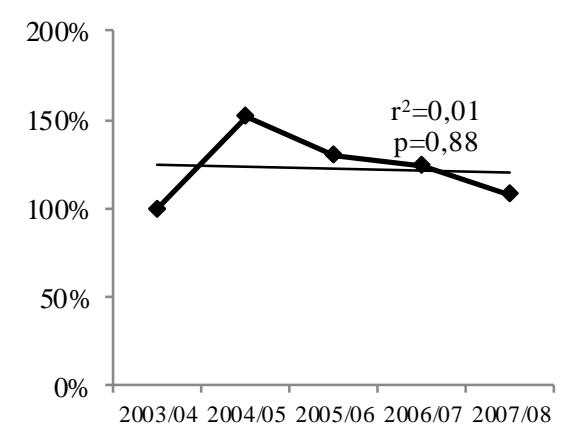

20. ábra: A kerceréce populációváltozás indexe Figure 20: Population index change of Goldeneye

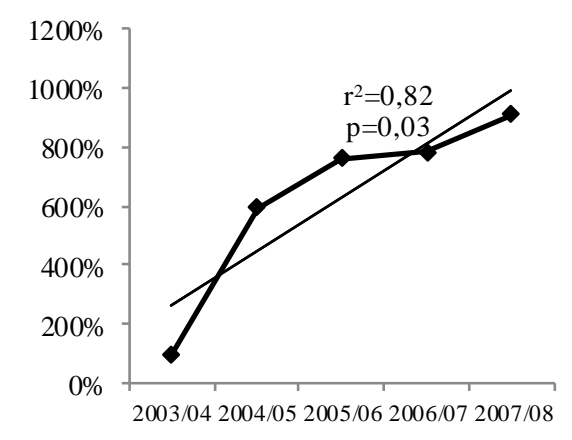

22. ábra: A búbos vöcsök populációváltozás indexe Figure 22: Population index change of Great Crested Grebe

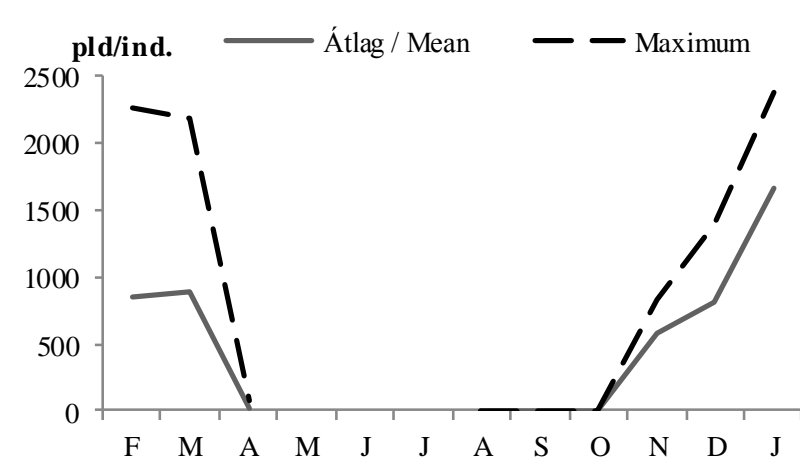

23. ábra: Kerceréce havi átlagos állománynagysága és maximuma a Balaton déli partján (2003-2008)

Figure 23: Monthly average and maximum population of Goldeneye on the southern shore of Lake Balaton (2003-2008)

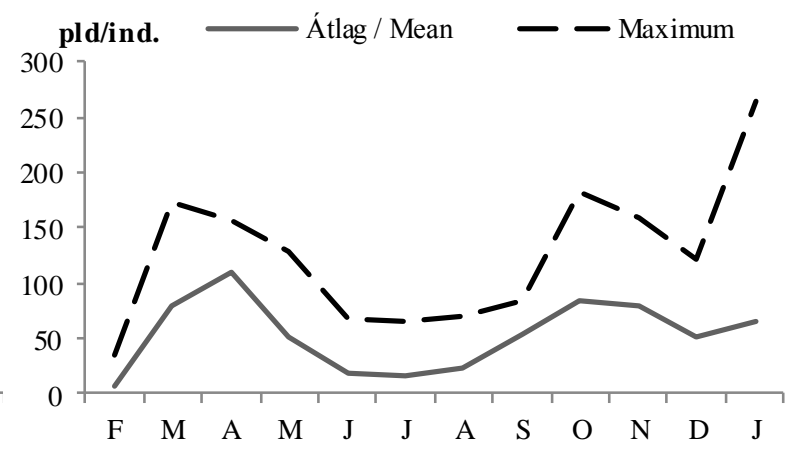

24. ábra: Búbos vöcsök havi átlagos állománynagysága és maximuma a Balaton déli partján (2003-2008)

Figure 24: Monthly average and maximum population of Great Crested Grebe on the southern shore of Lake Balaton (2003-2008) 


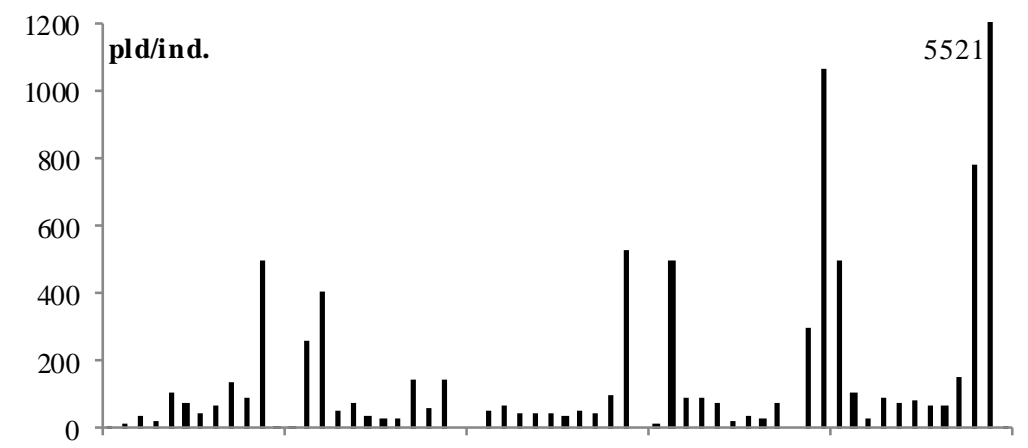

25. ábra: Kárókatona egyedszám a Balaton déli partján az egyes megfigyelési napokon (2003-2008)

Figure 25: Number of Great Cormorants on the southern shore of Lake Balaton, on the observation days (2003-2008)

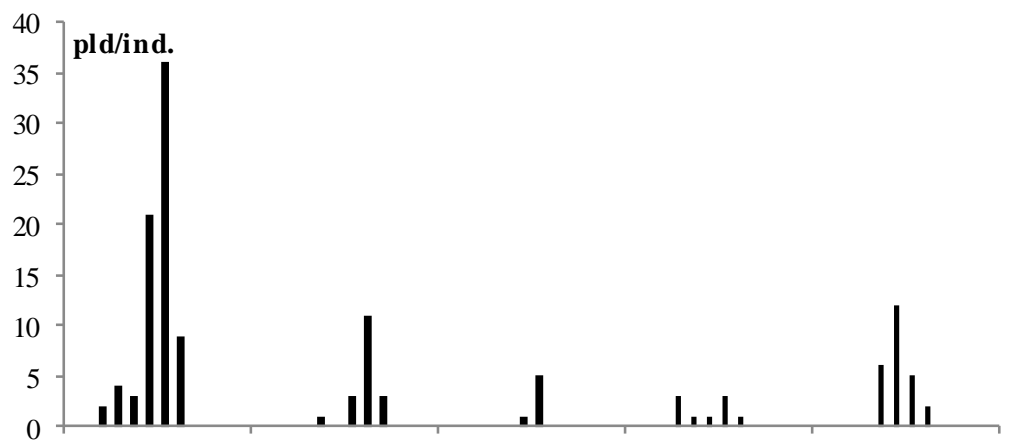

27. ábra: Kis kócsag egyedszám a Balaton déli partján az egyes megfigyelési napokon (2003-2008)

Figure 27: Number of Little Egrets on the southern shore of Lake Balaton, on the observation days (2003-2008)

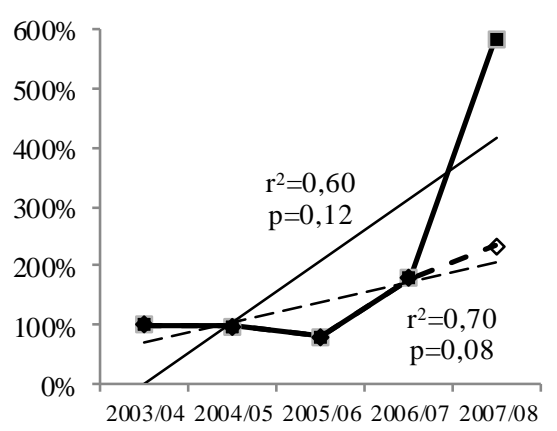

26. ábra: A kárókatona populációváltozás indexe Figure 26: Population index change of Great Cormorant

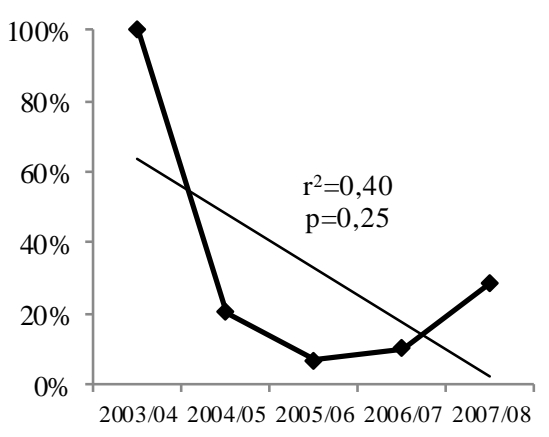

28. ábra: A kis kócsag populációváltozás indexe Figure 28: Population index change of Little Egret

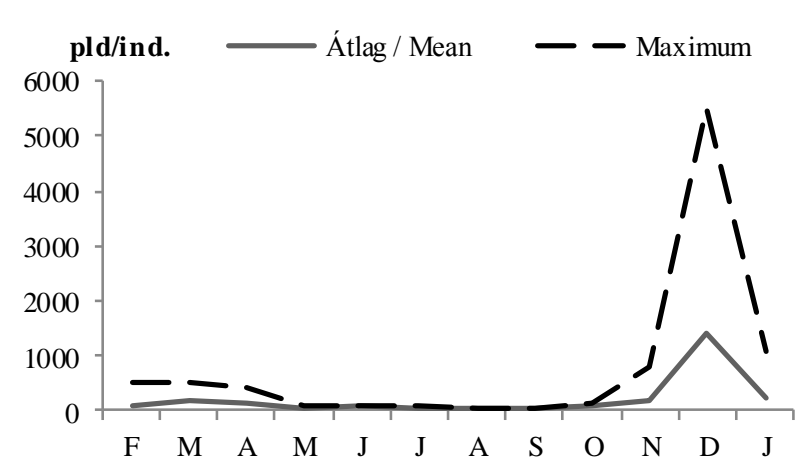

29. ábra: Kárókatona havi átlagos állománynagysága és maximuma a Balaton déli partján (2003-2008)

Figure 29: Monthly average and maximum population of Great Cormorant on the southern shore of Lake Balaton (2003-2008)

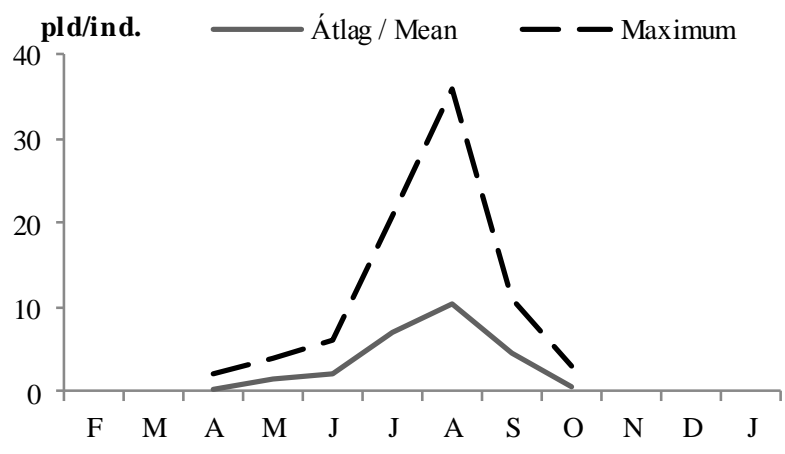

30. ábra: Kis kócsag havi átlagos állománynagysága és maximuma a Balaton déli partján (2003-2008)

Figure 30: Monthly average and maximum population of Little Egret on the southern shore of Lake Balaton (2003-2008) 


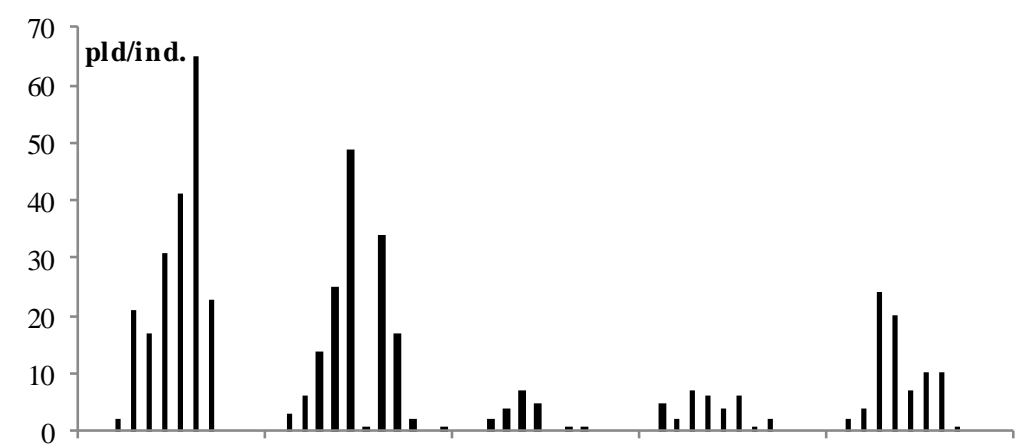

31. ábra: Nagy kócsag egyedszám a Balaton déli partján az egyes megfigyelési napokon (2003-2008) Figure 31: Number of Great Egrets on the southern shore of Lake Balaton, on the observation days (2003-2008)

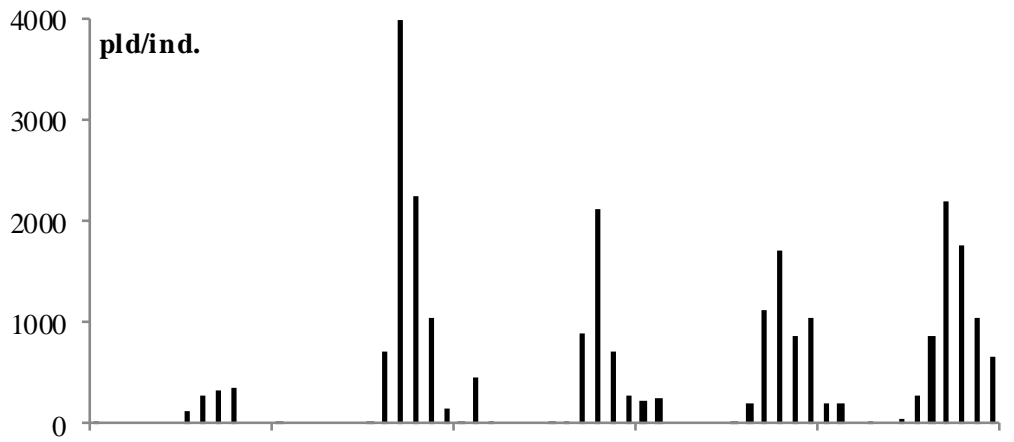

33. ábra: Szárcsa egyedszám a Balaton déli partján az egyes megfigyelési napokon (2003-2008)

Figure 33: Number of Coots on the southern shore of Lake Balaton, on the observation days (2003-2008)

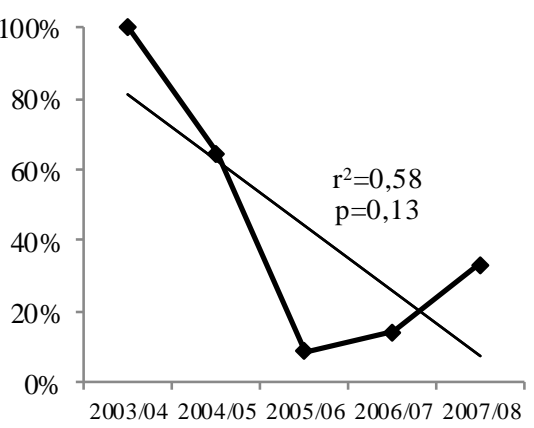

32. ábra: A nagy kócsag populációváltozás indexe Figure 32: Population index change of Great Egret

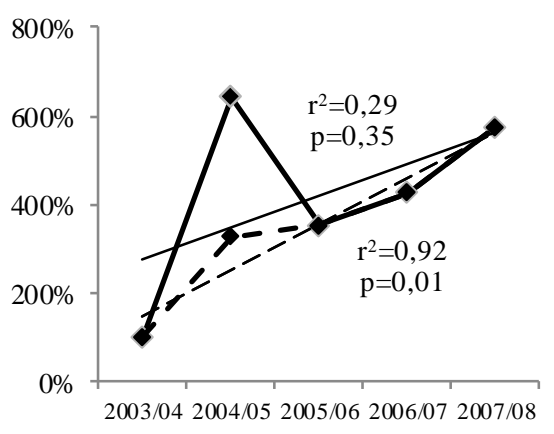

34. ábra: A szárcsa populációváltozás indexe Figure 34: Population index change of Coot

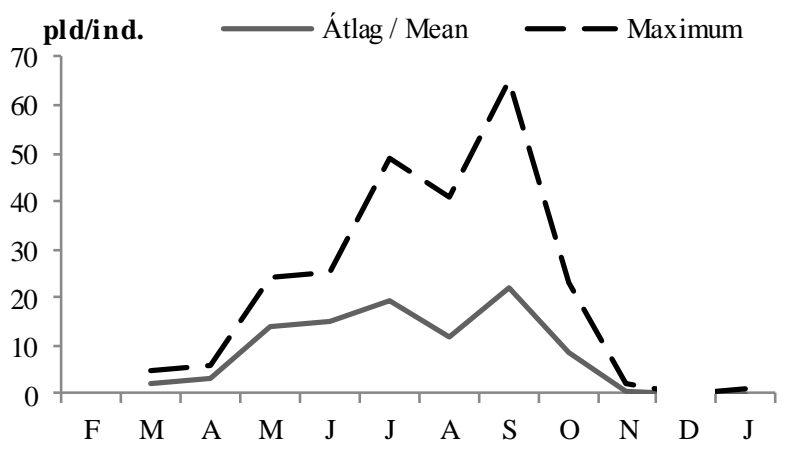

35. ábra: Nagy kócsag havi átlagos állománynagysága és maximuma a Balaton déli partján (2003-2008)

Figure 35: Monthly average and maximum population of Great Egret on the southern shore of Lake Balaton (2003-2008)

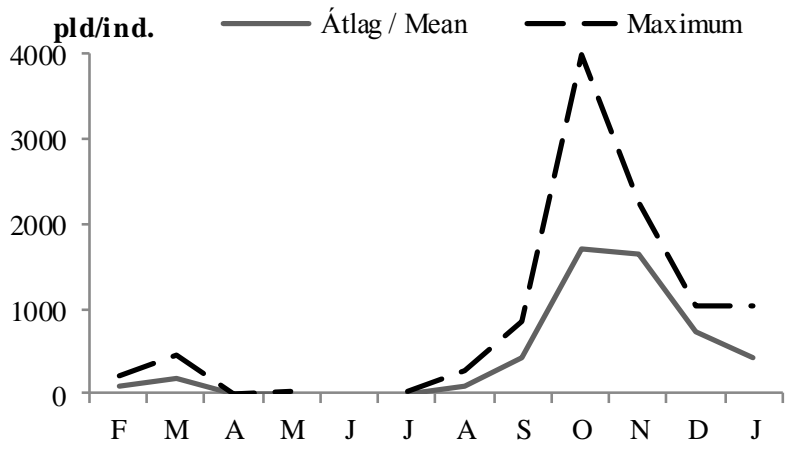

36. ábra: Szárcsa havi átlagos állománynagysága és maximuma a Balaton déli partján (2003-2008) Figure 36: Monthly average and maximum population of Coot on the southern shore of Lake Balaton (2003-2008) 


\section{Dankasirály (Larus ridibundus)}

A tökés réce után a második leggyakoribb faj a Balatonon. Az átlagos állománynagyság valamennyi évben kisebb volt, mint 2003-2004-ben (37. ábra, 6. táblázat). A populációváltozás index jól mutatja a tendenciát, miszerint a harmadik szezonig jelentős csökkenés, majd emelkedés (főként a 2007. januári kiugró érték miatt), ezt követően ismét csökkenés volt tapasztalható. Az egyes években számolt állománynagyságok ugyanakkor statisztikailag hasonlóak voltak, és valódi változás sem volt kimutatható (38. ábra).

Egész évben megfigyelhető. Kis egyedszámban fordult elö február (átlagállomány 64,8 pld) és május (70,0 pld) hónapokban. A költési időszak elmúltával száma növekedett, szeptemberben elérte a közel 1000 pld-os átlagot, a januári csúcs pedig ennek több mint kétszerese (2031,6 pld) volt. Meg kell jegyezni azonban, hogy utóbbi értéket a 2007. januári tömeges megjelenés határozta meg alapvetően. A déli parti átlagos állománynagyság júliustól januárig meghaladta a 400 pld-t (41. ábra).

Viharsirály (Larus canus)

Egyértelmü állományváltozási trend nem állapítható meg (40. ábra). A megfigyelt egyedek száma az évek során jelentős eltéréseket mutatott, bár ez szignifikánsnak nem nevezhető. (39. ábra, 6. táblázat)

Jellemzően novembertől márciusig fordult elö, illetve az utolsó évben két megfigyelési adata volt szeptemberben. A legtöbb egyedet januárban figyeltük meg (átlagos állománynagyság 294,6 pld), emellett a decemberi állománya is jelentős volt (209,2 pld) (42. ábra).

Sárgalábú/sztyeppi sirály (Larus michahellis/cachinnans)

Állománya a populációváltozás index alapján az öt év alatt harmadára csökkent (44. ábra), átlagos állománynagysága az első szezonhoz képest minden évben szignifikánsan kisebb volt. (43. ábra, 6. táblázat).

Egész évben megfigyelhető. Februárban és áprilisban az átlagos állománynagysága 50 pld alatt volt, a többi hónapokban 100 pld feletti, a csúcsát augusztusban érte el (613,6 pld). Augusztusban volt a leggyakoribb, ezen kívül júniustól novemberig, azaz három aspektusban volt rendszeresen megfigyelhető (47. ábra).

Bár a két faj arányaira vonatkozóan külön felmérést nem végeztünk, tapasztalataink szerint a sárgalábú sirály július-augusztusban (szeptember) fordul elő nagyobb számban, míg a sztyeppi sirály inkább október-novemberben jelenik meg tömegesen, decemberben pedig már dominánsabb.

Küszvágó csér (Sterna hirundo)

A vizsgált időszak alatt állománycsökkenést tapasztaltunk (46. ábra). Az első év után - a harmadik kivételével - minden következőben szignifikánsan kisebb volt az állomány (45. ábra, 6. táblázat).

Jellemzően áprilistól szeptemberig fordult elö, illetve egy alkalommal márciusban is megfigyeltük. A legtöbb egyedet július-augusztusban lehetett megfigyelni (átlagos állománynagyság 175,8; 176,4 pld) (48. ábra). 

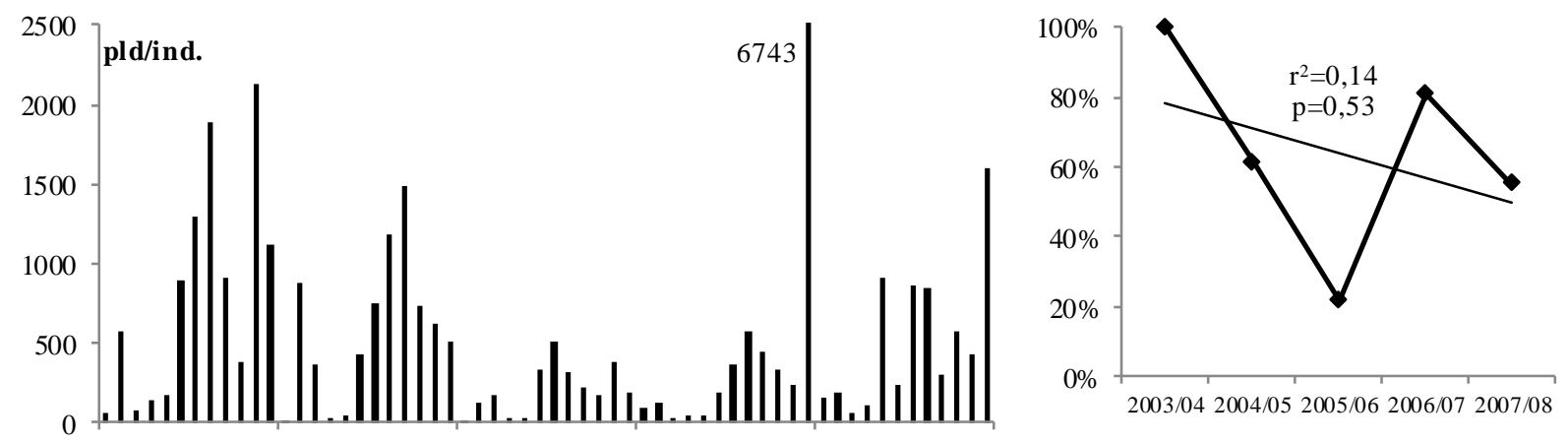

37. ábra Dankasirály egyedszám a Balaton déli partján az egyes megfigyelési napokon (2003-2008)

Figure 37: Number of Black-headed Gulls on the southern shore

of Lake Balaton, on the observation days (2003-2008)

38. ábra: A dankasirály populációváltozás indexe Figure 38: Population index change of Black-headed Gull
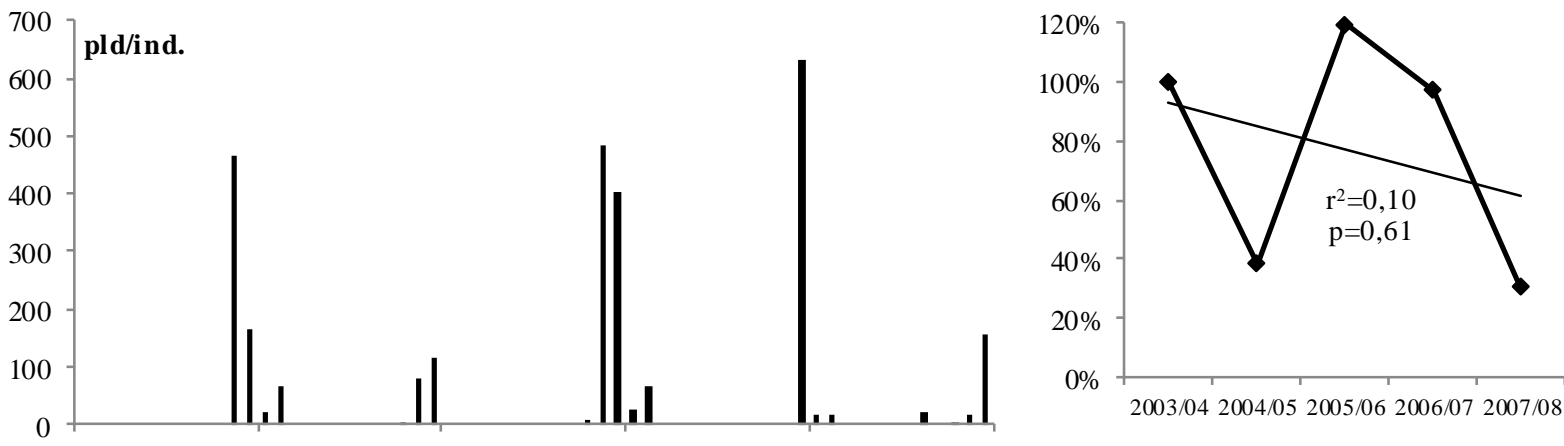

39. ábra: Viharsirály egyedszám a Balaton déli partján az egyes megfigyelési napokon (2003-2008)

Figure 39: Number of Mew Gulls on the southern shore of Lake Balaton, on the observation days (2003-2008)

40. ábra: A viharsirály populációváltozás indexe Figure 40: Population index change of Mew Gull

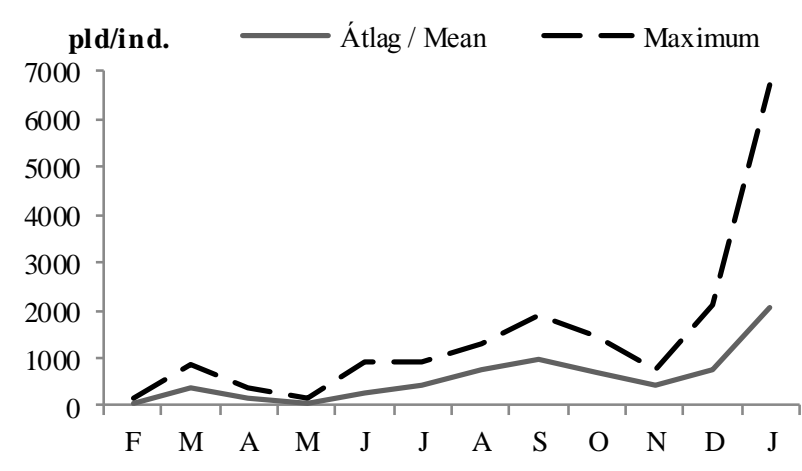

41. ábra: Dankasirály havi átlagos állománynagysága és maximuma a Balaton déli partján (2003-2008)

Figure 41: Monthly average and maximum population of Black-headed Gull on the southern shore of Lake Balaton (2003-2008)

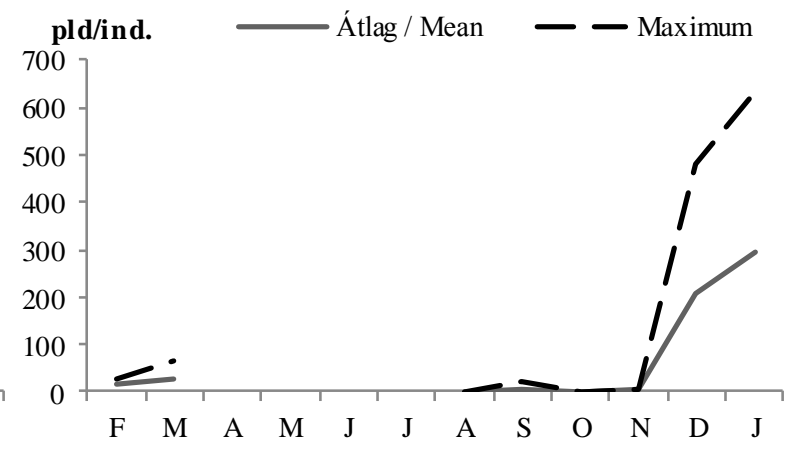

42. ábra: Viharsirály havi átlagos állománynagysága és maximuma a Balaton déli partján (2003-2008)

Figure 42: Monthly average and maximum population of Mew Gull on the southern shore of Lake Balaton (2003-2008) 


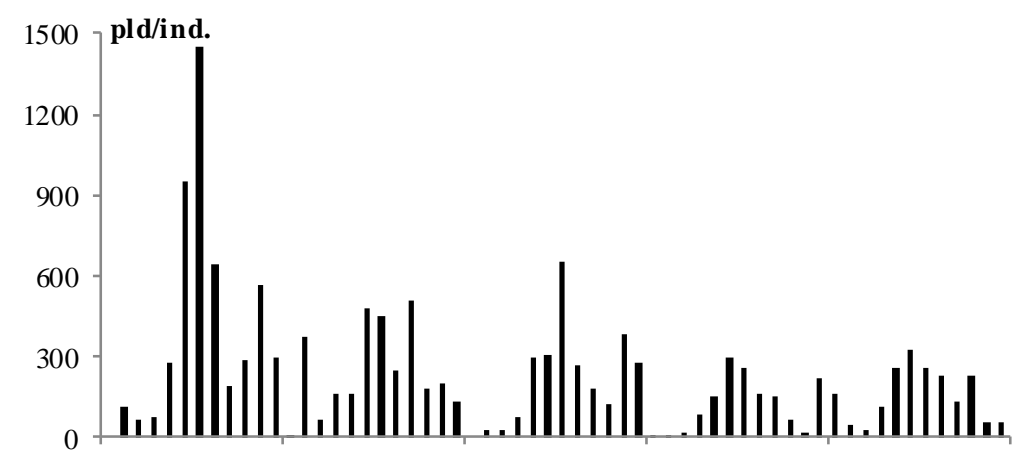

43. ábra Sárgalábú/sztyeppi sirály egyedszám a Balaton déli partján az egyes megfigyelési napokon (2003-2008)

Figure 43: Number of Yellow-legged/Caspian Gulls on the southern shore of Lake Balaton, on the observation days (20032008)

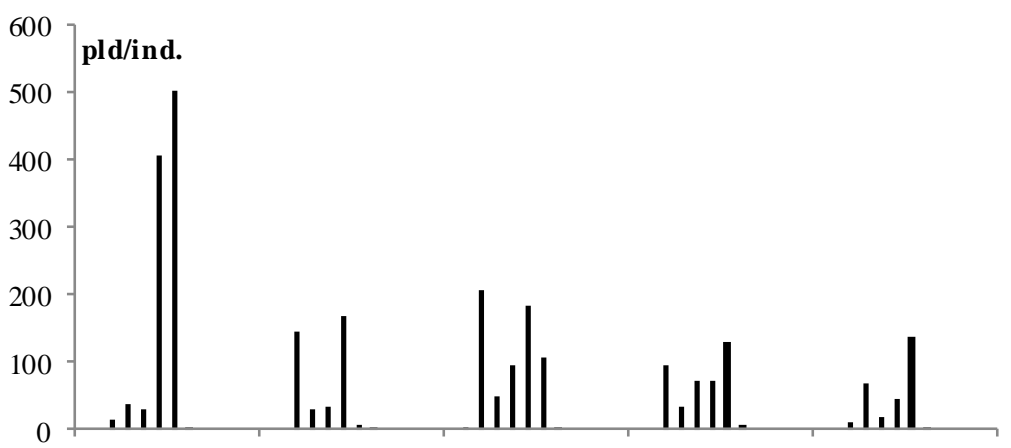

45. ábra: Küszvágó csér egyedszám a Balaton déli partján az egyes megfigyelési napokon (2003-2008)

Figure 45: Number of Common Terns on the southern shore of Lake Balaton, on the observation days (2003-2008)

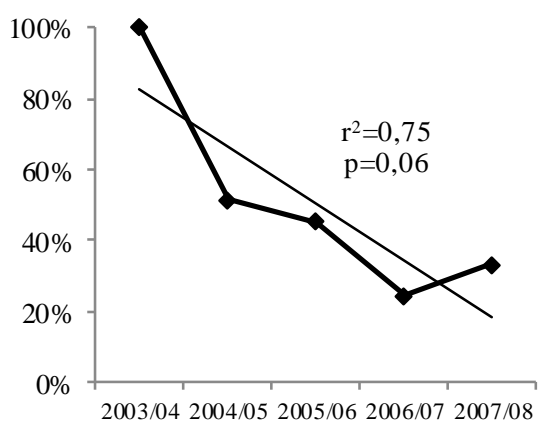

44. ábra: A sárgalábú/ sztyeppi sirály populációváltozás indexe Figure 44: Population index change of Yellow-legged/Caspian Gull

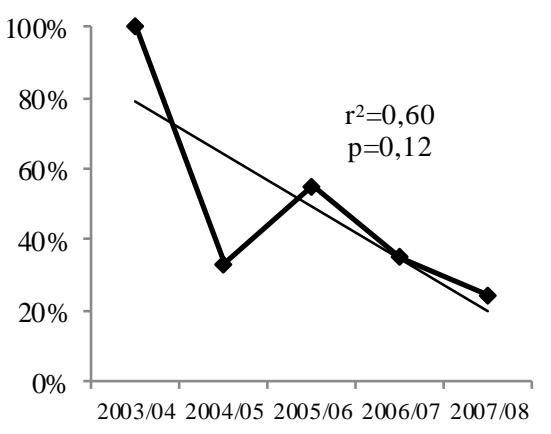

46. ábra: A küszvágó csér populációváltozás indexe Figure 46: Population index change of Common Tern

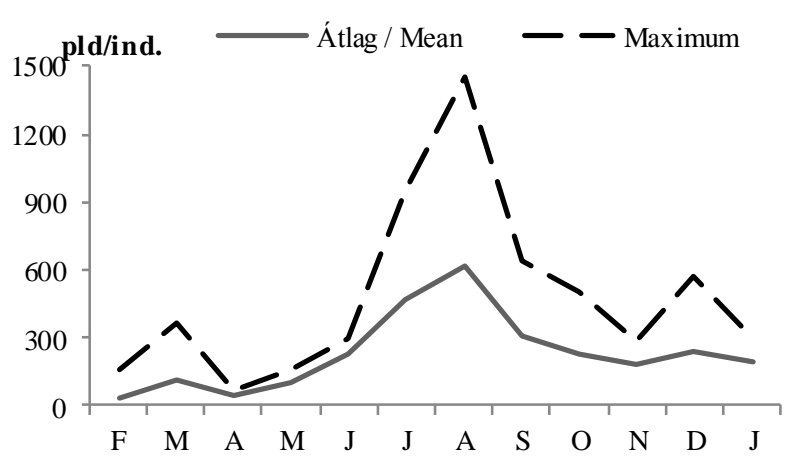

47 ábra: Sárgalábú/sztyeppi sirály havi átlagos állománynagysága és maximuma a

Balaton déli partján (2003-2008)

Figure 47: Monthly average and maximum population of Yellow-legged/Caspian Gull on the southern shore of Lake Balaton (2003-2008)

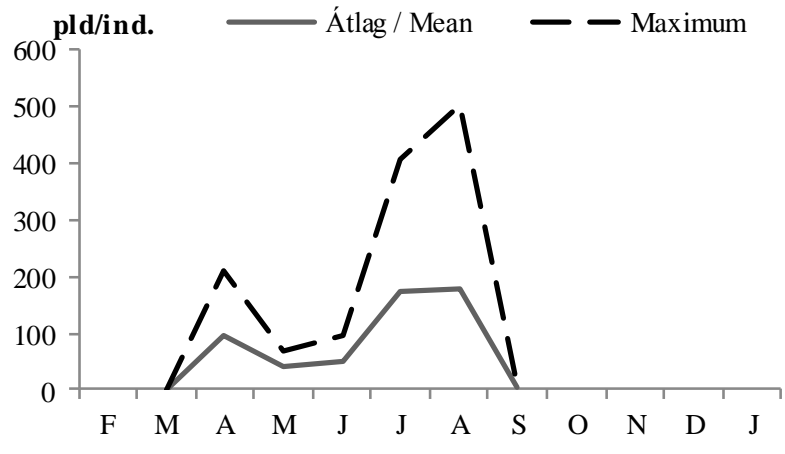

48. ábra: Küszvágó csér havi átlagos állománynagysága és maximuma a Balaton déli partján (2003-2008)

Figure 48: Monthly average and maximum population of Common Tern on the southern shore of Lake Balaton (2003-2008) 
A déli parti átlagos állománynagyság a tőkés réce esetében volt a legmagasabb $(>1000$ pld/megfigyelési nap), majd ezt követte a dankasirály, a szárcsa, a kerceréce stb. Az állománymaximum tekintetében a dankasirály érte el a legnagyobb tömegességet 6743 pld/megfigyelési nap (1. táblázat).

Az éves maximumok átlaga alapján 100 pld alatti, azaz tízes (nagy kócsag, kis kócsag), százas (sárgalábú/sztyeppi sirály, nyári lúd, kontyos réce, viharsirály, bütykös hattyú, küszvágó csér, búbos vöcsök, kanalas réce), illetve ezres (tökés réce, dankasirály, kerceréce, szárcsa, kárókatona, barátréce) nagyságrendü állományok állapíthatók meg (49. ábra).

1. táblázat: A gyakori vízimadárfajok átlag és maximum állományadatai a Balaton déli partján 2003-2008 között

Table 1: The average and the maximum population of common waterbird species on the southern shore of Lake Balaton between 2003-2008

\begin{tabular}{|c|c|c|c|c|c|c|}
\hline \multirow{2}{*}{$\begin{array}{c}\text { Faj } \\
\text { Species }\end{array}$} & \multirow{2}{*}{$\begin{array}{c}\text { Átlag/ } \\
\text { Mean } \\
\text { pld/ind. }\end{array}$} & \multicolumn{2}{|c|}{ Maximum } & \multicolumn{3}{|c|}{ Lokális/Local maximum } \\
\hline & & pld/ind. & Dátum/Date & pld/ind. & Hely/Plot & Dátum/Date \\
\hline Cygnus olor & 125,7 & 480 & 2004.10 .16 & 191 & Fonyód & 2004.10.16. \\
\hline Anser anser & 54,8 & 619 & 2006.01 .14 & 602 & Fonyód & 2006.01.14. \\
\hline Anas platyrhynchos & 1137,2 & 5572 & 2003.12.13. & 2644 & Balatonfenyves & 2003.12.13. \\
\hline Anas clypeata & 14,7 & 244 & 2004.10.16. & 163 & Balatonszemes & 2004.10.16. \\
\hline Aythya ferina & 263 & 2662 & 2004.03 .14 & 2500 & Bélatelepen & 2004.03.14. \\
\hline Aythya fuligula & 54,2 & 688 & 2007.11.10. & 680 & Balatonberény & 2007.11.10. \\
\hline Bucephala clangula & 402,3 & 2383 & 2008.01.13. & 2106 & Szántód & 2005.02.12. \\
\hline Podiceps cristatus & 53,4 & 265 & 2007.01.13. & 173 & Szántód & 2007.01.13. \\
\hline Phalacrocorax carbo & 218,7 & 5521 & 2007.12 .15 & 4500 & Szántód & 2007.12.15. \\
\hline Egretta garzetta & 2,2 & 36 & 2003.08 .16 & 16 & Balatonlelle & 2003.08.16. \\
\hline Egretta alba & 8,1 & 65 & 2003.09.13. & 26 & Fonyódliget & 2004.07.17. \\
\hline Fulica atra & 441,5 & 3996 & 2004.10.16. & 1830 & Szántód & 2004.10.16. \\
\hline Larus ridibundus & 576,9 & 6743 & 2007.01.13. & 5640 & Balatonszabadi & 2007.01.13. \\
\hline Larus canus & 46,2 & 634 & 2007.01.13. & 551 & Balatonszabadi & 2007.01.13. \\
\hline L. cachinnans/michahellis & 230,1 & 1451 & 2003.08.16. & 612 & Balatonszabadi & 2003.08.16. \\
\hline Sterna hirundo & 45,4 & 505 & 2003.08 .16 & 206 & Balatonszárszó & 2007.07.12. \\
\hline
\end{tabular}

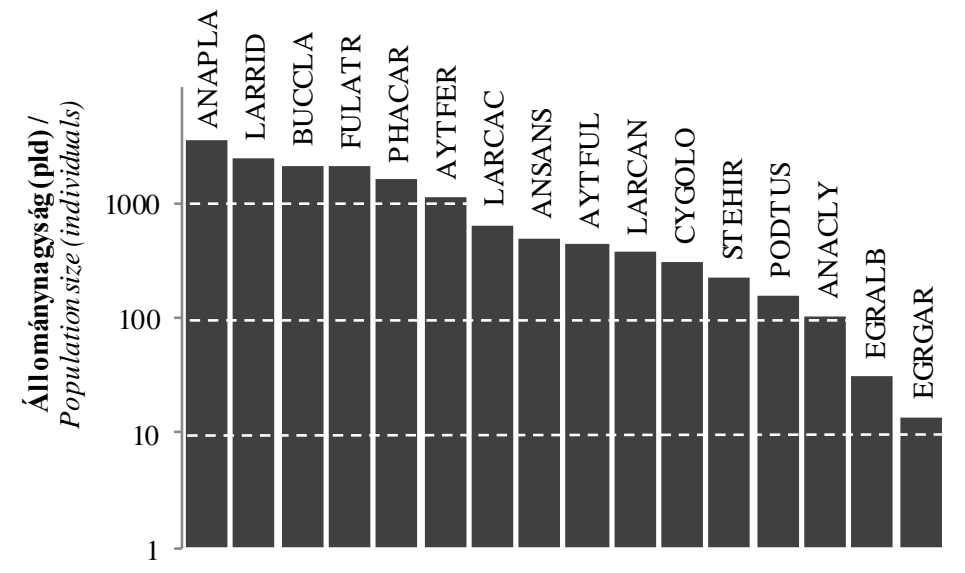

49. ábra: A gyakori vízimadár fajok állománynagysága az éves maximumok átlaga alapján a Balaton déli partján 2003-2008 között

Figure 49.: Population size of common waterbird species based on the average of annual maxima on the southern shore of Lake Balaton between 2003-2008 
A gyakori vízimadarak fenológiáját tekintve 7 faj volt egész évben jelen: a bütykös hattyú, a tőkés réce, a barátréce, a búbos vöcsök, a kárókatona, a dankasirály és a sárgalábú/sztyeppi sirály.

A gyakori fajok állománycsúcsa a következő időszakokban volt: búbos vöcsök április, október; kárókatona és tőkés réce december; bütykös hattyú szeptember; barátréce és kontyos réce november, március; kerceréce január, március; szárcsa október, november; dankasirály szeptember, január; viharsirály december, január; sárgalábú/sztyeppi sirály augusztus; küszvágó csér július; augusztus.

\subsection{Szórványos vízimadárfajok állományviszonyai}

\section{Vetési lúd (Anser fabalis)}

Az öt év alatt a faj 14 esetben történt megfigyelésének összegyedszáma 934 pld volt. A második évben a megfigyelt libák száma az első év kétszerese volt, majd folyamatosan csökkent, bár szignifikáns különbségeket nem lehett kimutatni, és a változás trendje sem igazolható statisztikailag (2. táblázat). A vizsgált balatoni partszakaszon való megjelenése nem gyakori, inkább a déli parti halastavakon és berkekben tartózkodnak. Általában kisebb, néhány százas csapatokban a nyári lúddal és a nagy lilikkel vegyesen figyeltük meg.

\section{Nagy lilik (Anser albifrons)}

A számolt összegyedszám (15 megfigyelés során) közel 1000 pld. A 2003-2004-es szezonhoz képest valamennyi évben több egyedet figyeltünk meg, a legnagyobb számban a másodikban, ugyanakkor lineáris összefüggés (növekedés) nem mutatható ki és az eltérések sem szignifikánsak (2. táblázat). Megjelenésére ugyanaz mondható el, mint a vetési lúd esetében, a Balatonon nem volt gyakran látható, akkor is vegyesen más lúdfajokkal fordult elő.

Fütyülő réce (Anas penelope)

Az esetek több mint felében 10 pld alatti állományt regisztráltuk egyidejűleg. Az első év után a következőkben kevesebb egyedet számoltunk, az eltérés csak a negyedik évben nem volt szignifikáns. A csökkenés tendenciája ugyanakkor nem tekinthető egyenletesnek (2. táblázat). A fütyülő réce elöfordulása a halastavakon, berkekben jóval gyakoribb.

Kendermagos réce (Anas strepera)

Partszakaszonként háromnál több egyed nem fordult elő. Az egyes években rendre 8, 11, 0, 3 és 8 pld-t figyeltünk meg, ami statisztikailag nem adott értékelhető eredményt (2. táblázat). A faj sem a Balatonon, sem a déli parti vizes élöhelyeken nem számít gyakorinak.

\section{Csörgő réce (Anas crecca)}

Az összesen regisztrált közel 700 egyed, 90\%-át az első évben figyeltük meg, ezt követően minden szezonban szignifikánsan kisebb (Tukey HSD Q $>5,34 ; \mathrm{p} \leq 0,001$ ) állományokat számoltunk (2. táblázat). A csökkenés trendje lineárisan nem illeszkedett jól. A fütyülő récéhez hasonlóan elsősorban a déli parti vizes élőhelyeken jelenik meg nagyobb számban és gyakrabban.

Nyílfarkú réce (Anas acuta)

Általában egy, vagy csak néhány egyedet figyeltünk meg a déli parton. Évente összesen 3-7 pld-t regisztráltunk, kivétel a második év, amikor 24 egyedet sikerült megfigyelni. Ezzel együtt a különbségek nem voltak szignifikánsak, továbbá egyértelmü állománycsökkenést sem lehetett igazolni (2. táblázat). 
Böjti réce (Anas querquedula)

Összesen 117 pld figyeltünk meg az öt év alatt. Bár az első évhez képest rendre nagyobb összegyedszámot számoltunk, lineáris állománynövekedésről nem beszélhetünk, valamint az adatok közötti eltérés sem volt szignifikáns (2. táblázat).

Üstökös réce (Netta rufina)

A megfigyelések több mint felében 10 pld alatti déli parti állományt észleltünk. Az egyes évek eredményei között számottevő ingadozást tapasztaltunk, ennek ellenére az átlagok gyakorlatilag hasonlóak voltak, továbbá egyértelmü állománynövekedést sem sikerült kimutatni (2. táblázat).

\section{Hegyi réce (Aythya marila)}

Általában csak néhány egyedet figyeltünk meg egyes helyeken, de három alkalommal 50-60as csapatokban is láttuk. A legtöbb egyedet a 2005-2006-os szezonban számoltuk, összesen 128 pld-t. Ezen kívül az első évhez képest rendre kevesebb madarat figyeltünk meg, de egyértelmü állománycsökkenés nem volt kimutatható, illetve a különbségek sem szignifikánsak (2. táblázat).

Kis bukó (Mergellus albellus)

Összesen 31 pld-t számoltunk. Az egyes évek között jelentős eltérések voltak, ennek ellenére ezek nem szignifikánsak, továbbá egyértelmü állományváltozást sem sikerült kimutatni (2. táblázat).

Sarki búvár (Gavia arctica)

A déli parton megfigyelt egyedek száma 1-7 között változott az egyes napokon. Az összesen 26 egyedből első évben csupán egy példányt, a másodikban egyet sem láttunk. A következő években a megfigyelt egyedek száma több mint tízszeresére növekedett, mely trend szignifikánsnak bizonyult (2. táblázat).

Kis kárókatona (Phalacrocorax pygmeus)

Összesen 24 példányát regisztráltuk, az 1., 2. és 5. években. Általában csak egy-két egyed jelent meg. Az állományváltozás a Balatonon nem volt szignifikáns (2. táblázat).

Szürke gém (Ardea cinerea)

Az összesen 27 egyedből 14-et az első évben láttunk, 7-et a másodikban, szignifikánsan kevesebbet, 2-2 példányt a többi évben. A balatoni megjelenése csökkenő tendenciát mutatott (2. táblázat). Jellemzően csak egy-két egyedet lehet megfigyelni partszakaszonként.

Rétisas (Haliaeetus albicilla)

Összesen 43 pld-t figyeltünk meg, ennek közel felét (21 pld-t) egy napon. Az éves átlagok között jelentős eltérés mutatkozott (2-23 pld), ennek ellenére statisztikailag a különbségek nem mutathatóak ki, ahogy az állománycsökkenés sem igazolható egyértelmüen (2. táblázat).

\section{Piroslábú cankó (Tringa totanus)}

Az első évben 16, a másodikban 2 példányát figyeltük meg, majd a következő években a vízszintemelkedés hatására a fövenyes élőhelyekkel együtt a faj is eltünt. Az észlelt napi állománynagysága $1-4$ egyed volt a déli parton (2. táblázat). 


\section{Billegetőcankó (Actitis hypoleucos)}

Összesen 60 pld-t figyeltünk meg, melynek 88\%-át az első két évben, a legtöbbet (42 pld) a második szezonban. Általában az egyes megfigyelési napokon összesen 1-2, a harmadik szezontól évente csupán 2-3 egyed fordult elő. A hirtelen állománycsökkenés, majd stagnálás lineáris trenddel nem jellemezhetö, valamint az egyes évek átlagai gyakorlatilag hasonlóak voltak (2. táblázat).

\section{Ezüstsirály (Larus argentatus)}

Általában 1-2 egyedet láttunk megfigyelésenként. Ritkán fordult elő ennél több példány, mindössze egyszer figyeltünk meg egy 6-os csapatot 2005 végén. Állománya erőteljesen, szignifikánsan csökkent az öt év alatt (2. táblázat). Meg kell jegyezni, hogy a faj terepi elkülönítése a sárgalábú és sztyeppi sirálynál felvetett problémához hasonlóan nem könnyü.

\section{Jégmadár (Alcedo atthis)}

Évente 4-6, összesen 24 pld-t figyeltünk meg. Az egyes évek adatai között gyakorlatilag nem volt eltérés, ennek megfelelően az állományváltozás nem volt kimutatható (2. táblázat). A legnagyobb előfordulás összesen 3 egyed volt a déli parton, 2005.11.12-én. Megfigyelésenként és helyenként csak egy-egy példánya fordult elö.

\section{2. táblázat: A szórványos vízimadárfajok állományváltozási trendjei az éves változás (slope) alapján, az átlagállományok szezonkénti összehasonlítása (ANOVA) és maximumai a Balaton déli partján}

Table 2: Population trends of scarce waterbird species according annual change (slope), the seasonal comparison of the average population (ANOVA) and the maximum population on the southern shore of Lake Balaton between 2003-2008

$(* \mathrm{p}=0,1 ; * * \mathrm{p}=0,05)$

\begin{tabular}{|c|c|c|c|c|c|c|c|c|c|c|}
\hline \multirow{2}{*}{$\begin{array}{c}\text { Faj } \\
\text { Species }\end{array}$} & \multicolumn{3}{|c|}{ Trend } & \multicolumn{2}{|c|}{ ANOVA } & \multicolumn{2}{|c|}{ Maximum } & \multicolumn{3}{|c|}{ Lokális/Local maximum } \\
\hline & Slope $(\%)$ & $\pm \mathbf{S E}$ & Irány/Classification & $\mathbf{F}$ & $\mathbf{p}$ & $\mathbf{p l d} /$ ind. & Dátum/Date & $\mathbf{p l d} /$ ind . & Hely/Site & Dátum/Date \\
\hline Anser fabalis & $-35,1$ & 20,2 & bizonytalan/uncertain & 0,86 & 0,49 & 429 & 2004.12.18. & 429 & Szabadi-Sóstó & 2004.12.18. \\
\hline Anser albifrons & 82,7 & 306,1 & bizonytalan/uncertain & 0,86 & 0,48 & 250 & 2007.11.10. & 250 & Balatonfenyves & 2007.11.10. \\
\hline Anas penelope & $-14,9$ & 9,7 & bizonytalan/uncertain & 3,28 & 0,01 & 65 & 2003.11.15. & 31 & Balatonszárszó & 2003.11.15. \\
\hline Anas strepera & $-11,5$ & 16,6 & bizonytalan/uncertain & - & - & 6 & 2007.11.10. & 3 & \multicolumn{2}{|c|}{ I. } \\
\hline Anas crecca & $-19,6$ & 11,1 & bizonytalan/uncertain & 5,31 & 0,000 & 337 & 2003.10 .18 & 220 & Fonyódliget & 2003.10 .18 \\
\hline Anas acuta & $-32,1$ & 33,3 & bizonytalan/uncertain & 2,14 & 0,07 & 7 & 2003.11.15. & 6 & \multicolumn{2}{|c|}{ II. } \\
\hline Anas querquedula & 109,9 & 120,3 & bizonytalan/uncertain & 1,01 & 0,40 & 48 & 2006.03 .18 & 20 & Balatonfenyves & 2005.03 .13 \\
\hline Netta rufina & 15,8 & 21,6 & bizonytalan/uncertain & 0,33 & 0,85 & 68 & 2006.10 .14 & 60 & Fonyódliget & 2006.10 .14 \\
\hline Aythya marila & $-17,7$ & 21,6 & bizonytalan/uncertain & 1,40 & 0,23 & 100 & 2005.12 .23 & 61 & Szántód & 2003.11.15. \\
\hline Mergellus albellus & $-19,9$ & 101,3 & bizonytalan/uncertain & 1,47 & 0,21 & 8 & 2008.01.13. & 8 & Szántód & 2008.01 .13 \\
\hline Gavia arctica & $* * 244$ & 52,2 & erös növ./strong inc. & - & - & 7 & 2007.04.14. & 7 & Balatonaliga & 2007.04 .14 \\
\hline Phalacrocorax pygmeus & 218,5 & 186,4 & bizonytalan/uncertain & - & - & 10 & 2007.08 .18 & 9 & Balatonszárszó & 2007.08 .18 \\
\hline Ardea cinerea & $*-20,7$ & 7,3 & erős csökk./steep decl. & 3,06 & 0,03 & 4 & 2004.06 .12 & 4 & Fonyódliget & 2004.06 .12 \\
\hline Haliaeetus albicilla & $-44,3$ & 36,9 & bizonytalan/uncertain & 2,17 & 0,07 & 12 & 2004.02 .14 & 10 & Fonyód & 2004.02 .14 \\
\hline Tringa totanus & $-21,1$ & 10,3 & bizonytalan/uncertain & - & - & 4 & III. & 4 & Fonyódliget & 2003.07.12. \\
\hline Actitis hypoleucos & $-47,2$ & 40,3 & bizonytalan/uncertain & 1,68 & 0,15 & 39 & 2004.08 .15 & 25 & Siófok & 2004.08 .15 \\
\hline Larus argentatus & $*-14,6$ & 4,9 & erös csökk./steep decl. & 0,58 & 0,68 & 6 & 2005.12 .23 & 6 & Szabadi-Sóstó & 2005.12 .23 \\
\hline Alcedo atthis & $-7,3$ & 6,7 & bizonytalan/uncertain & 0,21 & 0,93 & 3 & 2005.11.12. & 1 & - & - \\
\hline
\end{tabular}




\section{3. táblázat: A Balaton déli partján megfigyelt szórványos vízimadár fajok fenológiai (hónapok szerinti) összefoglaló táblázata (2003-2008)}

Table 3: Phenology of scarce waterbird species observed on the southern shore of Lake Balaton (2003-2008)

\begin{tabular}{|c|c|c|c|c|c|c|c|c|c|c|c|c|}
\hline \multirow{2}{*}{$\begin{array}{c}\text { Faj } \\
\text { Species }\end{array}$} & \multicolumn{12}{|c|}{ Hónapok / Months } \\
\hline & $\mathbf{F}$ & $\mathbf{M}$ & $\mathbf{A}$ & M & $\mathbf{J}$ & $\mathbf{J}$ & $\mathbf{A}$ & $\mathbf{S}$ & O & $\mathbf{N}$ & D & $\mathbf{J}$ \\
\hline \multicolumn{13}{|l|}{ GAVARC } \\
\hline \multicolumn{13}{|l|}{ PHAPYG } \\
\hline \multicolumn{13}{|l|}{ ARDCIN } \\
\hline \multicolumn{13}{|l|}{ ANSFAB } \\
\hline \multicolumn{13}{|l|}{ ANSALB } \\
\hline \multicolumn{13}{|l|}{ ANAPEN } \\
\hline \multicolumn{13}{|l|}{ ANASTR } \\
\hline \multicolumn{13}{|l|}{ ANACRE } \\
\hline \multicolumn{13}{|l|}{ ANAACU } \\
\hline \multicolumn{13}{|l|}{ ANAQUE } \\
\hline \multicolumn{13}{|l|}{ NETRUF } \\
\hline \multicolumn{13}{|l|}{ AYTMAR } \\
\hline \multicolumn{13}{|l|}{ MERALB } \\
\hline \multicolumn{13}{|l|}{ HALALB } \\
\hline \multicolumn{13}{|l|}{ TRITOT } \\
\hline \multicolumn{13}{|l|}{ АCTHYP } \\
\hline \multicolumn{13}{|l|}{ LARARG } \\
\hline ALCATT & & & & & & & & & & & & \\
\hline
\end{tabular}

\subsection{Ritka vízimadárfajok faunisztikai adatai}

A ritka fajok megfigyelési adatait az alábbiakban csak felsorolásszerüen ismertetem. Zárójelben adtam meg a módszertani fejezetben felsorolt megfigyelők monogramját.

Fekete hattyú (Cygnus atratus): 2004.12.18., Balatonszabadi, 2 pld (PE, SG); 2005.01.15., Fonyód, 1 pld (KM, KGY).

Bütykös ásólúd (Tadorna tadorna): 2003.12.13., Ordacsehi, 1 pld; Balatonszemes, 6 pld (KM, KGY); 2004.11.19., Balatonboglár, 1 pld (KGY); 2007.11.10., Balatonfenyves, 9 pld (FÁ, GSZ).

Cigányréce (Aythya nyroca): 2004.03.14., Balatonaliga, 2 pld (LA); 2004.09.18., Balatonfenyves, 1 pld (BZS); 2006.10.14., Zamárdi, 2 pld (KGY); 2007.09.15., Ordacsehi, 1 pld (KGY); 2007.11.10., Balatonaliga, 1 pld (JR, KGY); Ordacsehi, 1 pld (FÁ, GSZ).

Pehelyréce (Somateria mollissima): 2003.11.15., Balatonföldvár, 1 pld (LA); 2005.09.16., Balatonaliga, 1 pld (KRASSOVÁn KrisZTina, IG, PA, PreisZner BÁLINT, SG); 2005.10.14., Balatonlelle, 1 pld (KGY).

Jegesréce (Clangula hyemalis): 2007.12.15., Balatonlelle-felső, 1 pld (KGY); 2008.01.13., Szántód, 3 pld (BB, BG, IG, PA, PN, ZSCS, SZJ, FE, MA, MT).

Fekete réce (Melanitta nigra): 2003.11.15., Balatonberény, 1 pld (BZS); 2007.11.10., Balatonberény, 1 pld; Balatonboglár, 1 pld (FÁ, GSZ); 2007.12.15., Balatonszárszó, 1 pld (KGY); 2008.01.13., Szántód, 2 pld (BB, BG, IG, PA, PN, ZSCS, SZJ, FE, MA, MT).

Füstös réce (Melanitta fusca): 2004.11.19., Szántód, 2 pld (PE, PA 2005.11.12., Szántód, 1 pld (BG, HG, PB, UB, VN); 2005.12.23., Szántód, 15 pld (KGY); 2006.11.25., Balatonlelle, 1 pld (KGY); 2006.04.15., Zamárdi, 5 pld (SZJ); 2006.01.14., Szántód, 12 pld (VN, BZ, BG, PB); 2007.01.13., Balatonlelle, 2 pld (KGY); 2008.01.13., Szántód, 2 pld (BB, BG, IG, PA, PN, ZSCS, SZJ, FE, MA, MT).

Örvös bukó (Mergus serrator): 2004.11.19., Balatonföldvár, 2 pld (PE, PA); 2005.11.12., Balatonszabadi, 3 pld (SG); 2007.11.10., Balatonberény, 1 pld (FÁ, GSZ).

Nagy bukó (Mergus merganser): 2003.03.15., Fonyód, 2 pld (KGY, VB); 2004.11.19., Balatonföldvár, 2 pld (PE, PA); 2005.03.13., Szántód, 2 pld (IG, MA, MT, SG, PA); 2005.12.23., Balatonaliga, 2 pld (KGY); 2006.02.18., Szántód, 1 pld (SZJ, IG, PA, SG); 2006.01.14., Balatonaliga, 1 pld (VN, BZ, BG, PB).

Északi búvár (Gavia stellata): 2004.11.19., Balatonföldvár, 1 pld (PE, PA); 2007.11.10., Balatonberény, 1 pld (FÁ, GSZ); 2008.01.13., Szántód, 1 ad. pld (BB, BG, IG, PA, PN, ZSCS, SZJ, FE, MA, MT). 
Jeges búvár (Gavia immer): 2006.11.25., Szántód, 1 pld (FE, JR, SZJ, SG); 2006.12.16., Szántód, 1 pld (SZJ); 2007.03.17., Szántód, 1 pld (JR, MA); 2007.02.17., Szántód, 1 pld (IG, JL, KAT, SG, SZJ).

Kis vöcsök (Tachybaptus ruficollis): 2004.02.14., Szántód, 1 pld (LA); 2004.10.16., Zamárdi, 1 pld (IG, PA); 2007.11.10., Balatonszemes, 1 pld (FÁ, GSZ); 2007.10.13., Balatonboglár, 2 pld (KGY); 2007.12.15., Balatonboglár, 1 pld (KGY); 2008.01.13., Szántód, 3 pld (BB, BG, IG, PA, PN, ZSCS, SZJ, FE, MA, MT).

Vörösnyakú vöcsök (Podiceps grisegena): 2003.11.15., Balatonföldvár, 1 pld (LA); 2004.11.19., Balatonlelle, 1 pld (KGY); 2005.10.14., Ordacsehi, 2 pld (KGY); Balatonaliga, 2 pld (IG, PA); 2005.11.12., Balatonlelle, 1 pld (KM, KGY); 2007.01.13., Szántód, 1 pld (PA, IG, KAN, KAT); 2007.11.10., Balatonboglár, 1 pld (FÁ, GSZ).

Füles vöcsök (Podiceps auritus): 2004.11.19., Siófok, 1 pld (PE, PA).

Feketenyakú vöcsök (Podiceps nigricollis): 2004.11.19., Szántód, 1 pld; Balatonszabadi, 1 pld (PE, PA); 2006.12.16., Siófok, 1 pld (SZJ); 2007.11.10., Szántód, 1 pld; Zamárdi, 1 pld (JR, KGY); 2007.10.13., Balatonaliga, 1 pld (PA, IG).

Bakcsó (Nycticorax nycticorax): 2003.06.14., Balatonberény, 1 pld (BZS); 2004.06.12., Ordacsehi, 1 pld (KGY); 2005.05.14., Balatonmáriafürdő, 1 pld (BZS); 2006.06.15., Balatonlelle-felső, 3 pld (KGY); 2007.05.12., Ordacsehi, 1 pld (KGY); 2007.06.17., Balatonboglár, 1 pld (KGY).

Vörös gém (Ardea purpurea): 2004.05.15., Balatonszemes, 1 pld (KGY, VB); 2004.06.12., Balatonföldvár, 1 pld (FARKAS PÉTER, SG); 2004.07.17., Ordacsehi, 1 pld (KM, KGY); 2007.07.14., Balatonlelle-felső, 1 pld (KGY).

Fehér gólya (Ciconia ciconia): 2003.07.12., Balatonmáriafürdő, 1 pld (BZS); 2006.07.15., Balatonszárszó, 1 pld (KGY).

Barna rétihéja (Circus aeruginosus): 2004.06.12., Zamárdi, 1 pld (FARKAS PÉTER, SG); 2004.08.15., Szántód, 1 pld (PA, SG).

Héja (Accipiter gentilis): 2004.09.18., Sóstó, 1 pld (IG, PA, SG); 2005.10.14., Balatonszárszó, 1 pld (KGY). Karvaly (Accipiter nisus): 2003.12.13., Balatonföldvár, 1 pld (PA, IG, LA); 2004.12.18., Zamárdi, 1 pld (PE, SG); 2005.04.16., Zamárdi, 1 pld (PE, SG); 2006.03.18., Balatonföldvár, 1 pld (SZJ, IG, PA, PE, JL, GA, MT, MA, SG); 2006.02.18., Balatonaliga, 1 pld (SZJ, IG, PA, SG); 2008.01.13., Szántód, 1 pld (BB, BG, IG, PA, PN, ZSCS, SZJ, FE, MA, MT).

Egerészölyv (Buteo buteo): 2003.04.13., Balatonlelle-felső, 1 pld (VB, MGY); 2004.03.14., Balatonszabadi, 1 pld (LA); 2004.11.19., Szántód, 1 pld (PE, PA); 2005.03.13., Szántód, 1 pld (IG, MA, MT, SG, PA); 2007.06.17., Szántód, 1 pld (IG, JL, PA); 2007.12.15., Szántód, 1 pld (MMJ, FE, MA); 2008.01.13., Szántód, 2 pld (BB, BG, IG, PA, PN, ZSCS, SZJ, FE, MA, MT).

Vándorsólyom (Falco peregrinus): 2004.02.14., Siófok, 1 pld (LA); 2005.02.12., Zamárdi, 1 pld (PA, IG, SG).

Vízityúk (Gallinula chloropus): 2003.06.14., Balatonboglár, 5 pld (KGY); 2003.07.12., Balatonboglár, 1 pld (KGY); Balatonszabadi, 1 pld (LA); 2003.08.16., Balatonboglár, 1 pld (KGY, VB); 2003.09.13., Szántód, 2 pld (KM, LA, SG); 2004.07.17., Ordacsehi, 1 pld (KM, KGY); 2006.11.25., Balatonberény, 1 pld (BZS, CSA); 2007.11.10., Balatonberény, 1 pld; Balatonszemes, 1 pld (FÁ, GSZ).

Csigaforgató (Haematopus ostralegus): 2003.09.13., Balatonberény, 3 pld (BZS).

Gólyatöcs (Himantopus himantopus): 2003.08.16., Ordacsehi, 5 pld; Balatonboglár, 1 pld; Balatonszemes, 1 pld (KGY, VB); 2003.09.13., Balatonlelle-felső, 1 pld; Balatonszemes, 5 pld (KGY, VB).

Kis lile (Charadrius dubius): 2003.07.12., Ordacsehi, 3 pld (KGY); 2003.08.16., Ordacsehi, 1 pld; Balatonszemes, 2 pld (KGY, VB); 2003.09.13., Balatonszemes, 3 pld (KGY, VB).

Parti lile (Charadrius hiaticula): 2003.08.16., Ordacsehi, 1 pld (KGY, VB).

Ezüstlile (Pluvialis squatarola): 2003.10.18., Balatonberény, 5 pld (BZS); Fonyód, 3 pld (KGY).

Bíbic (Vanellus vanellus): 2003.03.01., Balatonföldvár, 8 pld (KM, LA, SG); 2003.10.18., Balatonszabadi, 2 pld (SV, SG); 2004.03.14., Balatonszabadi, 1 pld (LA); 2006.03.18., Szántód, 57 pld; Zamárdi, 70 pld (SZJ, IG, PA, PE, JL, GA, MT, MA, SG).

Sarki partfutó (Calidris canutus): 2004.08.15., Balatonboglár, 1 pld (KGY).

Fenyérfutó (Calidris alba): 2003.09.13., Balatonberény, 2 pld (BZS); Balatonszemes, 1 pld (KGY, VB).

Apró partfutó (Calidris minuta): 2003.09.13., Balatonszemes, 2 pld (KGY, VB); 2004.09.18., Balatonboglár, 1 pld (KGY).

Sarlós partfutó (Calidris ferruginea): 2003.09.13., Balatonszemes, 3 pld (KGY, VB). 
Havasi partfutó (Calidris alpina): 2003.09.13., Balatonfenyves, 1 pld (BZS); Balatonszemes, 38 pld (KGY, VB); 2003.10.18., Balatonberény, 15 pld (BZS); Fonyód, 28 pld (KGY); 2003.12.13., Balatonboglár, 4 pld (KM, KGY); 2004.09.18., Balatonboglár, 2 pld (KGY).

Pajzsoscankó (Philomachus pugnax): 2003.08.16., Balatonszemes, 10 pld (KGY, VB); 2003.09.13., Balatonlelle-felső, 6 pld; Balatonszemes, 1 pld (KGY, VB); 2003.10.18., Balatonfenyves, 2 pld (BZS).

Kis goda (Limosa lapponica): 2003.08.16., Balatonszemes, 10 pld (KGY, VB); 2003.09.13., Ordacsehi, 2 pld (KGY, VB); 2004.09.18., Balatonboglár, 1 pld (KGY).

Nagy póling (Numenius arquata): 2003.12.13., Balatonfenyves, 5 pld (BZS).

Füstös cankó (Tringa erythropus): 2003.09.13., Balatonberény, 1 pld (BZS); Ordacsehi, 6 pld; Balatonszemes, 28 pld; Balatonszárszó, 13 pld (KGY, VB); 2003.10.18., Fonyód, 4 pld; Balatonszárszó, 44 pld (KGY); Balatonföldvár, 4 pld (SV, SG); 2004.10.16., Ordacsehi, 20 pld (KGY).

Tavi cankó (Tringa stagnatilis): 2003.08.16., Fonyód, 2 pld; Ordacsehi, 1 pld; Balatonszemes, 5 pld (KGY, VB).

Szürke cankó (Tringa nebularia): 2003.07.12., Ordacsehi, 40 pld (KGY); 2003.09.13., Balatonszárszó, 2 pld (KGY, VB).

Erdei cankó (Tringa ochropus): 2003.08.16., Fonyód, 27 pld (KGY, VB).

Réti cankó (Tringa glareola): 2003.08.16., Ordacsehi, 5 pld; Balatonboglár, 1 pld; Balatonszemes, 6 pld (KGY, VB).

Köforgató (Arenaria interpres): 2007.09.15., Ordacsehi, 1 pld (KGY).

Szerecsensirály (Larus melanocephalus): 2003.07.12., Balatonberény, 1 pld (BZS).

Kis sirály (Hydrocoloeus minutus): 2003.08.16., Balatonlelle, 10 pld (KGY, VB); 2004.07.17., Ordacsehi, 2 pld; Balatonboglár, 1 pld (KM, KGY); 2004.08.15., Szántód, 5 pld (PA, SG); 2005.08.13., Szántód, 10 pld (LA); 2005.10.14., Balatonaliga, 1 pld (IG, PA); 2006.04.15., Szántód, 4 pld (SZJ); 2007.07.14., Balatonföldvár, 1 pld (SZJ, SG); 2007.08.18., Szántód, 7 pld (IG, JL, PA).

Heringsirály (Larus fuscus): 2003.12.13., Ordacsehi, 1 pld (KM, KGY); 2004.10.16., Balatonszabadi, 1 pld (IG, PA); 2007.01.13., Balatonszabadi, 1 pld (PA, IG, KAN, KAT).

Csüllö (Rissa tridactyla): 2004.11.19., Szántód, 1 pld (PE, PA).

Kacagócsér (Gelochelidon nilotica): 2007.09.15., Balatonlelle-felső, 1 pld (KGY).

Lócsér (Sterna caspia): 2003.07.12., Ordacsehi, 3 pld (KGY); 2007.04.14., Szántód, 3 pld (IG, JL).

Kormos szerkő (Chlidonias niger): 2004.05.15., Balatonberény, 5 pld (BZS); 2005.04.16., Fonyód, 3 pld (KGY); 2005.05.14., Siófok, 12 pld (IG, PA); 2006.04.15., Szántód, 5 pld (SZJ); 2007.09.15., Szántód, 12 pld (JR, $\mathrm{MA})$.

\section{4. ÉRTÉKELÉS}

\subsection{Faunisztikai értékelés}

Összesítve az eredményeket az abundancia alapján a jelentősebb vízimadár taxonok a következők voltak: Anatidae (56,3\%), Laridae (22,8\%), Rallidae (föként szárcsa) $(11,8 \%$ ), Phalacrocoracidae (5,8\%), Podicipedidae (1,4\%), Sternidae (1,2\%) (összesen 99,4\%).

Összehasonlítva KEVE $(1972 b ; 1973 ; 1978)$ saját és más megfigyelök több évtizedes összesített adataival, valamint BANKOVICS (1985; 1997) és NAGY et al. (2008) teljes Balatonra vonatkozó felméréseivel megállapítható, hogy a tó madárfaunájáról igen részletes képet adott a vizsgálat (4. táblázat).

Fontos megjegyezni, hogy a monitoringnak nem a faunisztikai felmérés a célja, hanem a mennyiségi viszonyok, illetve trendek, folyamatok megállapítása. 


\section{4. táblázat: A Balatonon megfigyelt vízimadár fajok rendek szerinti megoszlása az egyes szerzők alapján}

Table 4: Distribution of waterbird species observed on Lake Balaton according to taxonomic orders after different authors' works

\begin{tabular}{lccccc}
\hline Rend/Order & KEVE (1972b; & $\begin{array}{c}\text { BANKOVICS } \\
\text { 1973a; 1978b) }\end{array}$ & $\begin{array}{c}\text { HAVRANEK } \text { et al. (1995), } \\
\text { HAVRANEK (1995; 1996) }\end{array}$ & $\begin{array}{c}\text { NAGY } \text { et al. } \\
(\mathbf{2 0 0 8})\end{array}$ & $\begin{array}{c}\text { KováCs } \\
(\mathbf{2 0 0 3 - 2 0 0 8 )}\end{array}$ \\
\hline Gaviiformes & 3 & 4 & 2 & 3 & 3 \\
Podicipediformes & 4 & 4 & 3 & 5 & 5 \\
Pelecaniformes & 2 & 1 & 1 & 2 & 2 \\
Ciconiiformes & 12 & 2 & 3 & 7 & 6 \\
Anseriformes & 24 & 24 & 18 & 26 & 26 \\
Gruiformes & 9 & 2 & 6 & 3 & 2 \\
Charadriiformes & 55 & 8 & 16 & 33 & 35 \\
\hline Vízimadár fajok összesen: & 109 & 45 & 49 & 79 & 79 \\
Waterbird species total: & & & &
\end{tabular}

\subsection{Természetvédelmi értékelés}

A megfigyelt fajokat természetvédelmi szempontból többféleképpen osztályoztam (5. táblázat). A hazai védettség (13/2001. (V. 9.) KöM rendelet, 100/2012. (IX. 28.) VM rendelet) alapján $57(67 \%)$ védett, $21(25 \%)$ fokozottan védett és $3(4 \%)$ az Európai Közösségben természetvédelmi szempontból jelentős faj.

Az IUCN Vörös Lista (IUCN, 2012) szerint 81 faj (95\%) nem veszélyeztetett, az Aythya nyroca és a Numenius arquata mérsékelten veszélyeztetett, a Clangula hyemalis sebezhetö, a Melanitta fusca veszélyeztetett.

A SPEC (Species of European Conservation Concern) kategóriáknak (TUCKER \& HeAth, 1994; BiRdLIFE InTERnATIONAL, 2004) megfelelően a Phalacrocorax pygmeus, az Aythya nyroca és a Haliaeetus albicilla világszerte veszélyeztetett. Európában kedvezőtlen védelmi helyzetü 7 faj (8\%), amelyek költő vagy telelő állományának több mint 50\%-a Európában van; illetve 23 faj (27\%), amelyek költő vagy telelő állományának kevesebb mint 50\%-a van Európában. További 51 faj (60\%) Európában kedvező védelmi helyzetü.

Madárvédelmi Irányelv (79/409/EGK tanácsi irányelv, 2009/147/EK tanácsi irányelv) tekintetében 26 faj (31\%) minősíthető veszélyeztetettnek (I. függelék).

A Bonni Egyezmény (1986. évi 6. törvényerejü rendelet) alapján 65 (76\%) kedvezőtlen védelmi helyzetủ vándorló fajt figyeltünk meg. Az egyezményt kiegészítő AEWA hatálya alá (2003. évi XXXIII. törvény) pedig 76 faj (89\%) tartozik.

A Berni Egyezmény (1990/7. KTM) besorolása szerint 2 faj (2\%) védett, 40 (47\%), fokozottan védett státuszú.

A Ramsari Egyezmény (1993. évi XLII. törvény) 6. kritériumának (a vizes élőhely rendszeresen egy vízimadár faj vagy alfaj populációjának legalább 1\%-át tartja el) 1\%-os állományküszöb értékeit (WETLANDS INTERNATIONAL 2002; 2006; 2012a; 2012b) az alábbi fajok teljesítették a vizsgált periódusban. A kárókatona 2007. decemberben, a nagy lilik 2004. januárban. A nyári lúd esetében 2003. december, 2004. november és december, 2005. január, 2006. január és november, 2007. november. A kerceréce 2003 novemberében és decemberében, 2004 februárjában, márciusában és decemberében, 2005 januárjában, februárjában és decemberében, 2006 márciusában, 2007 és 2008 januárjában. A ramsari 5. kritérium (a vizes élőhely rendszeresen 20000 vagy annál több vízimadarat tart el) kizárólag a déli part tekintetében nem teljesült. Ugyanakkor több esetben, az egész Balatont figyelembe véve a következő megfigyelési napokon a tó nagy valószínűséggel eleget tett a kritériumnak: 2003. 
december (11 926 pld), 2004. október (10 524 pld), 2007. január (16 634 pld), 2007. december (10 969 pld). Ezt a feltevést megerösíthetjük azzal, hogy - föként télen - a Keszthelyi-öbölben (Keszthely, Vonyarcvashegy) ezres nagyságrendü récecsapatok aggregálódtak (KovÁcs, 2008c, 2008d, 2008e), illetve a tavon tartózkodó libák tömegeit (BANKOVICS, 1985; HAVRANEK, 1996b; NAGY et al., 2008) általában nem sikerült megfigyelni, a szinkron metodikai okaiból kifolyólag.

\section{5. táblázat: A Balaton déli partján megfigyelt vízimadarak természetvédelmi besorolása (2003-2008)}

Table 5: Conservation status of waterbirds observed on the southern shore of Lake Balaton (20032008)

\begin{tabular}{|c|c|c|c|c|c|c|c|c|c|c|c|c|c|}
\hline $\begin{array}{c}\text { Faj } \\
\text { Species }\end{array}$ & $\begin{array}{c}\text { Hazai } \\
\text { védettség }\end{array}$ & $\begin{array}{l}\text { IUCN } \\
\text { Vörös } \\
\text { Lista }\end{array}$ & $\underset{\text { kategóriák }}{\text { SPEC }}$ & $\begin{array}{l}\text { Madár- } \\
\text { védelmi } \\
\text { Irányelv }\end{array}$ & $\begin{array}{c}\text { Bonni } \\
\text { Egyezm. }\end{array}$ & $\begin{array}{c}\text { Berni } \\
\text { Egyezm. }\end{array}$ & $\begin{array}{c}\text { Faj } \\
\text { Species }\end{array}$ & $\begin{array}{c}\text { Hazai } \\
\text { védettség }\end{array}$ & $\begin{array}{l}\text { IUCN } \\
\text { Vörös } \\
\text { Lista }\end{array}$ & $\begin{array}{c}\text { SPEC } \\
\text { kategóriák }\end{array}$ & $\begin{array}{l}\text { Madár- } \\
\text { védelmi } \\
\text { Irányelv }\end{array}$ & $\begin{array}{c}\text { Bonni } \\
\text { Egyezm. }\end{array}$ & $\begin{array}{c}\text { Berni } \\
\text { Egyezm. }\end{array}$ \\
\hline GAVSTE & $\mathrm{V}$ & LC & SPEC 3 & I & * & II & ACCGEN & $\mathrm{V}$ & $\mathrm{LC}$ & Non-SPEC & - & II & II \\
\hline GAVARC & $\mathrm{V}$ & LC & $\mathrm{SPEC} 3$ & I & * & II & ACCNIS & $\mathrm{V}$ & $\mathrm{LC}$ & Non-SPEC & - & II & II \\
\hline GAVIMM & $\mathrm{V}$ & LC & Non-SPEC & I & * & II & BUTBUT & $\mathrm{V}$ & LC & Non-SPEC & - & II & II \\
\hline TACRUF & V & LC & Non-SPEC & - & * & II & FALPER & FV & LC & Non-SPEC & I & II & II \\
\hline PODTUS & $\mathrm{V}$ & $\mathrm{LC}$ & Non-SPEC & - & * & & GALCHL & $\mathrm{V}$ & $\mathrm{LC}$ & Non-SPEC & $\mathrm{II} / 2$ & * & \\
\hline PODENA & FV & LC & Non-SPEC & - & * & II & FULATR & - & $\mathrm{LC}$ & Non-SPEC & $\mathrm{II} / 1, \mathrm{III} / 2$ & * & \\
\hline PODAUR & $\mathrm{V}$ & LC & $\mathrm{SPEC} 3$ & I & * & II & HAEOST & $\mathrm{V}$ & $\mathrm{LC}$ & Non-SPEC ${ }^{\mathrm{E}}$ & $\mathrm{II} / 2$ & * & \\
\hline PODNIG & $\mathrm{FV}$ & LC & Non-SPEC & - & $*$ & II & HIMHIM & $\mathrm{FV}$ & LC & Non-SPEC & I & $\mathrm{II}^{*}$ & II \\
\hline PHACAR & $\mathrm{EU}$ & $\mathrm{LC}$ & Non-SPEC & - & * & & CHADUB & $\mathrm{V}$ & $\mathrm{LC}$ & Non-SPEC & - & $\mathrm{II}^{*}$ & II \\
\hline PHAPYG & $\mathrm{FV}$ & LC & SPEC 1 & I & $*$ & II & CHAHIA & $\mathrm{V}$ & $\mathrm{LC}$ & Non-SPEC ${ }^{\mathrm{E}}$ & - & II* & II \\
\hline NYCNYC & $\mathrm{FV}$ & LC & SPEC 3 & I & * & II & PLUSQU & $\mathrm{V}$ & $\mathrm{LC}$ & Non-SPEC & $\mathrm{II} / 2$ & II* & \\
\hline EGRGAR & $\mathrm{FV}$ & LC & Non-SPEC & I & * & II & VANVAN & $\mathrm{V}$ & $\mathrm{LC}$ & SPEC 2 & $\mathrm{II} / 2$ & $\mathrm{II}^{*}$ & \\
\hline EGRALB & FV & LC & Non-SPEC & I & * & II & CALCAN & V & LC & $\operatorname{SPEC} 3 \mathrm{~W}$ & $\mathrm{II} / 2$ & II* & \\
\hline ARDCIN & V & LC & Non-SPEC & - & * & & CALALB & V & $\mathrm{LC}$ & Non-SPEC & - & II* & II \\
\hline ARDPUR & $\mathrm{FV}$ & $\mathrm{LC}$ & $\mathrm{SPEC} 3$ & I & * & II & CALMIN & $\mathrm{V}$ & $\mathrm{LC}$ & Non-SPEC & - & $\mathrm{II}^{*}$ & II \\
\hline CICCIC & FV & $\mathrm{LC}$ & SPEC 2 & I & II* & II & CALFER & $\mathrm{V}$ & $\mathrm{LC}$ & $\mathrm{n} / \mathrm{a}$ & - & II* & II \\
\hline CYGOLO & $\mathrm{EU}$ & LC & Non-SPEC $C^{\mathrm{E}}$ & $\mathrm{II} / 2$ & II* & & CALALP & V & LC & SPEC 3 & - & $\mathrm{II}^{*}$ & II \\
\hline ANSFAB & - & LC & Non-SPEC ${ }^{E} W$ & II/1 & II* & & PHIPUG & V & LC & SPEC 2 & $\mathrm{I}, \mathrm{II} / 2$ & $\mathrm{II}^{*}$ & \\
\hline ANSALB & - & $\mathrm{LC}$ & Non-SPEC & $\mathrm{III} / 2$ & II* & & LIMLAP & $\mathrm{V}$ & $\mathrm{LC}$ & Non-SPEC & $\mathrm{I}, \mathrm{II} / 2$ & $\mathrm{II}^{*}$ & \\
\hline ANSANS & $\mathrm{V}$ & LC & Non-SPEC & $\mathrm{II} / 1, \mathrm{III} / 2$ & II* & & NUMARQ & $\mathrm{FV}$ & NT & SPEC 2 & $\mathrm{II} / 2$ & $\mathrm{II}^{*}$ & \\
\hline TADTAD & $\mathrm{V}$ & LC & Non-SPEC & - & II* & II & TRIERY & $\mathrm{V}$ & $\mathrm{LC}$ & SPEC 3 & $\mathrm{II} / 2$ & $\mathrm{II}^{*}$ & \\
\hline ANAPEN & V & LC & Non-SPEC ${ }^{E} \mathrm{~W}$ & II $/ 1, \mathrm{III} / 2$ & $\mathrm{II}^{*}$ & & TRITOT & $\mathrm{FV}$ & LC & SPEC 2 & $\mathrm{II} / 2$ & $\mathrm{II}^{*}$ & \\
\hline ANASTR & $\mathrm{V}$ & LC & SPEC 3 & II/1 & $\mathrm{II}^{*}$ & & TRISTA & $\mathrm{FV}$ & LC & Non-SPEC & - & $\mathrm{II}^{*}$ & II \\
\hline ANACRE & $\mathrm{V}$ & LC & Non-SPEC & $\mathrm{II} / 1, \mathrm{III} / 2$ & $\mathrm{II}^{*}$ & & TRINEB & V & LC & Non-SPEC & $\mathrm{II} / 2$ & II* & \\
\hline ANAPLA & - & $\mathrm{LC}$ & Non-SPEC & II/1, III/1 & $\mathrm{II}^{*}$ & & TRIOCH & V & $\mathrm{LC}$ & Non-SPEC & - & $\mathrm{II}^{*}$ & II \\
\hline ANAACU & $\mathrm{V}$ & $\mathrm{LC}$ & SPEC 3 & $\mathrm{II} / 1, \mathrm{III} / 2$ & II* & & TRIGLA & $\mathrm{V}$ & $\mathrm{LC}$ & SPEC 3 & I & II* & II \\
\hline ANAQUE & $\mathrm{FV}$ & LC & SPEC 3 & $\mathrm{II} / 1$ & $\mathrm{II}^{*}$ & & ACTHYP & V & LC & SPEC 3 & - & II & II \\
\hline ANACLY & $\mathrm{V}$ & LC & SPEC 3 & $\mathrm{II} / 1, \mathrm{III} / 2$ & $\mathrm{II}^{*}$ & & AREINT & V & $\mathrm{LC}$ & Non-SPEC & - & II* & II \\
\hline NETRUF & $\mathrm{V}$ & LC & Non-SPEC & $\mathrm{II} / 2$ & II* & & PHAFUL & V & LC & Non-SPEC & - & II* & II \\
\hline AYTFER & $\mathrm{V}$ & $\mathrm{LC}$ & SPEC 2 & $\mathrm{II} / 1, \mathrm{III} / 2$ & II* & & LARMEL & $\mathrm{FV}$ & $\mathrm{LC}$ & Non-SPEC ${ }^{\mathrm{E}}$ & I & II* & II \\
\hline AYTNYR & $\mathrm{FV}$ & NT & SPEC 1 & I & II* & & LARMIN & $\mathrm{V}$ & $\mathrm{LC}$ & SPEC 3 & I & $\mathrm{II}^{*}$ & II \\
\hline AYTFUL & $\mathrm{V}$ & LC & SPEC 3 & $\mathrm{II} / 1, \mathrm{III} / 2$ & $\mathrm{II}^{*}$ & & LARRID & $\mathrm{V}$ & LC & Non-SPEC ${ }^{\mathrm{E}}$ & $\mathrm{II} / 2$ & II* & \\
\hline AYTMAR & V & LC & SPEC $3 \mathrm{~W}$ & $\mathrm{II} / 2, \mathrm{III} / 2$ & II* & & LARCAN & $\mathrm{V}$ & LC & SPEC 2 & $\mathrm{II} / 2$ & II* & \\
\hline SOMMOL & $\mathrm{V}$ & $\mathrm{LC}$ & Non-SPEC ${ }^{\mathrm{E}}$ & $\mathrm{II} / 2, \mathrm{III} / 2$ & $\mathrm{II}^{*}$ & & LARFUS & $\mathrm{V}$ & $\mathrm{LC}$ & Non-SPEC ${ }^{\mathrm{E}}$ & $\mathrm{II} / 2$ & $\mathrm{II}^{*}$ & III \\
\hline CLAHYE & $\mathrm{FV}$ & $\mathrm{VU}$ & Non-SPEC & $\mathrm{II} / 2$ & $\mathrm{II}^{*}$ & & LARARG & V & LC & Non-SPEC $C^{\mathrm{E}}$ & $\mathrm{II} / 2$ & $\mathrm{II}^{*}$ & III \\
\hline MELNIG & $\mathrm{V}$ & $\mathrm{LC}$ & Non-SPEC & $\mathrm{II} / 2, \mathrm{III} / 2$ & $\mathrm{II}^{*}$ & & LARCAC & $\mathrm{EU}$ & $\mathrm{LC}$ & Non-SPEC ${ }^{\mathrm{E}}$ & $\mathrm{II} / 2$ & II* & \\
\hline MELFUS & FV & EN & SPEC 3 & $\mathrm{II} / 2$ & $\mathrm{II}^{*}$ & & RISTRI & V & LC & Non-SPEC & - & & \\
\hline BUCCLA & $\mathrm{V}$ & LC & Non-SPEC & $\mathrm{II} / 2$ & $\mathrm{II}^{*}$ & & GELNIL & V & LC & SPEC 3 & I & II* & II \\
\hline MERALB & $\mathrm{V}$ & LC & SPEC 3 & I & II* & & STECAS & $\mathrm{V}$ & LC & SPEC 3 & I & $\mathrm{II}^{*}$ & II \\
\hline MERSER & $\mathrm{V}$ & $\mathrm{LC}$ & Non-SPEC & $\mathrm{II} / 2$ & II* & & STEHIR & $\mathrm{FV}$ & $\mathrm{LC}$ & Non-SPEC & I & $\mathrm{II}^{*}$ & II \\
\hline MERMER & V & LC & Non-SPEC & $\mathrm{II} / 2$ & II* & & CHLNIG & $\mathrm{FV}$ & LC & SPEC 3 & I & $\mathrm{II}^{*}$ & II \\
\hline HALALB & $\mathrm{FV}$ & LC & SPEC 1 & I & II & II & ALCATT & V & LC & SPEC 3 & I & & II \\
\hline CIRAER & $\mathrm{V}$ & $\mathrm{LC}$ & Non-SPEC & I & II & II & & & & & & & \\
\hline
\end{tabular}

Hazai védettség (13/2001. (V. 9.) KöM rendelet, 100/2012. (IX. 28.) VM rendelet): V - védett, FV - fokozottan védett, EU - az Európai Közösségben természetvédelmi szempontból jelentős faj.

IUCN Vörös Lista v. 2012.1 (IUCN, 2012): EN - endangered/veszélyeztetett, VU - vulnerable/sebezhető, NT - near threatened/mérsékelten veszélyeztetett, LC - least concern/nem veszélyeztetett.

SPEC (Species of European Conservation Concern) kategória (BIRDLIFE INTERNATIONAL, 2004): SPEC 1 - világszerte veszélyeztetett fajok; SPEC 2 - Európában kedvezőtlen védelmi helyzetü fajok, amelyek költő vagy telelő állományának több, mint 50\%-a Európában van; SPEC 3 - Európában kedvezőtlen védelmi helyzetű fajok, amelyek költő vagy telelő állományának kevesebb, mint 50\%-a van Európában; Non-SPEC ${ }^{\mathrm{E}}$ - Európában kedvező védelmi helyzetü fajok, amelyek költő vagy telelö állományának több, mint 50\%-a Európában van; Non-SPEC - Európában kedvező védelmi helyzetü fajok, amelyek költő vagy telelő állományának kevesebb, mint $50 \%$-a van Európában; W - telelő állomány.

Madárvédelmi Irányelv (79/409/EGK tanácsi irányelv, 2009/147/EK tanácsi irányelv): I., II/1., II/2., III/1., III/2., III/3. függelék.

Bonni Egyezmény (a vándorló, vadon élő állatfajok védelme), AEWA (megállapodás az afrikai-eurázsiai vándorló vízimadarak védelméről): I. veszélyeztetett vándorló fajok, II. kedvezőtlen védelmi helyzetű vándorló fajok, *AEWA II. függelék.

Berni Egyezmény (az európai vadon élő élővilág és a természetes élőhelyek védelme): II. függelék - fokozottan védett fajok, III. függelék - védett fajok. 


\subsection{A gyakori vízimadárfajok állománynagysága}

Összesítve a gyakori vízimadárfajok állományviszonyait két faj esetében határozható meg 100 pld alatti (nagy kócsag, kis kócsag), 8 fajnál százas (sárgalábú/sztyeppi sirály, nyári lúd, kontyos réce, viharsirály, bütykös hattyú, küszvágó csér, búbos vöcsök, kanalas réce), további 6 faj esetében ezres (tőkés réce, dankasirály, kerceréce, szárcsa, kárókatona, barátréce) nagyságrendủ állománynagyság (49. ábra).

A bütykös hattyú a 20. század végéig viszonylag ritka fajnak számított, majd az 1970es években telepedett meg. Az 1980-as évektől már rendszeresen lehetett látni egy-egy példányt (BANKOVICS, 1985; SzINAI, 1998). A század végére a tó Magyarország legjelentősebb vedlőhelye, 1997-ben 450-500 egyed végezte itt a vedlését, a balatoni költőállomány pedig 3540 pár volt (SzINAI, 1997). Az ezredfordulóra a fészkelők száma 40 pár fölött volt, a vedlök száma pedig 450-600 egyed (ALBERT et al., 2004). NAGY et al., (2008) balatoni maximális állományadatai nagyságrendileg 600-900 pld, jelen vizsgálat alapján a Dél-Balatonon 180-480 egyed.

A vadludak közül legnagyobb számban a nyári lúd fordult elö, állománynagysága 400600 egyed, melyek kivétel nélkül telelő csapatok voltak. KEVE (1978), STERBETZ (1975), BANKOVICS (1985), HAVRANEK et al. (1995) és HAVRANEK (1996b) még kis számú, NAGY et al., (2008) a teljes Balatonon 400-2000-es állományról számoltak be, amelyek a libák közül a déli parton dominánsak. Fontos megjegyezni, hogy az alkalmazott vízimadár-felmérési módszer nem alkalmas - az életmódjukból fakadóan - a libák állománybecslésére. A Magyar Vadlúd Monitoring déli parti felmérőhelyén (Kelet-Balaton) végzett számlálások alapján (FARAGÓ, 2005a; 2006a; 2007a; 2007c; 2008a; 2010b) a nyári lúd aránya csupán az utolsó két szezonban nőtt meg. A teljes Balatonon végzett téli szinkronok alkalmával (KovÁCs, 2008d; 2008e) a nyári lúd volt dominánsabb a többi vadlúdfajhoz képest.

A megfigyelt vízimadarak több mint felét $(50,6 \%)$ a récék, közel negyedét $(24,1 \%)$ a sirályok, további jelentős részét $(11,8 \%)$ pedig a szárcsák tették ki. A récéken belül az úszórécék (61,6\%) túlsúlya volt tapasztalható a bukórécékhez $(38,4 \%)$ képest, ellentétben KEVE (1968; 1970a) a Keszthelyi-medencére vonatkozó, továbbá BANKOVICS (1985), NAGY et al. (2008) és KovÁcs (2008c; 2008d) teljes balatoni vizsgálataival, ahol a bukórécéknek nagyobb jelentőséget tulajdonítottak. Felméréseink alapján csupán 2007. év végén volt több $(52,8 \%)$ úszóréce az egész Balatonon (KovÁcs, 2008e).

Az úszórécék, illetve az összes vízimadárfajt tekintve a legnagyobb számban előforduló (abszolút domináns) faj a tőkés réce volt, déli parti állománynagysága 2600-5600 pld. NAGY et al. (2008) szerint balatoni állománya 5300-9600 pld volt, ami szintén jóval alulmúlta BANKOVICS (1985) által számolt 1980-as évekbeli 19400 pld-os tetőzését. Míg KEVE (1970a) korábban több ezres csoportosulásokról írt a déli part egy-egy szakaszán, addig esetünkben csak két alkalommal sikerült 2000-es csapatokat megfigyelni, általában százas nagyságrendben gyülekeztek.

A kanalas réce jóval kisebb számban jelent meg. Az alacsony vízálláskor, az első két évben 130-240 példányt számoltunk, ugyanekkor NAGY et al. (2008) 270-280 egyedet. Később jóval kevesebb jelent meg, 30-100 pld. KEVE (1970a) és BANKOVICS (1985) jellemzően szintén kis számban figyelte meg, előbbi szerző azalatt több százas kis-balatoni mennyiségekről számolt be.

A barátréce déli parti állománya 520-2700 pld volt. Az egész Balatonra BANKOVICS (1985) korábban 4000 pld feletti, NAGY et al. (2008) 1200-3200 pld-os állományt adott meg.

A kontyos récét az első és a harmadik évben igen kis számban figyeltük meg, a többi szezonban 600-700 egyed fordult elő. A teljes balatoni szinkronok alkalmával 500-2500 pld-t számoltunk, ezalatt NAGY et al. (2008) 900-3200 pld-t. Mindegyik esetben a 2006-2007-es 
szezon bizonyult a leggyengébbnek. BANKOVICS (1985) 2500-4100-as állománynagyságot közölt, de KEVE (1968) is gyakran figyelt meg Keszthelyen több százas, esetenként ezer feletti csapatokat.

A kerceréce állománya az első kivételével (1400 pld) valamennyi évben 2000 pld felett (2200-2400 pld), NAGY et al. (2008) esetében az egész tóra vonatkozóan 2800-5600 egyed volt. A kontyos récéhez hasonlóan KEVE (1968) rendszeresen számolt tömeges, több alkalommal 1000-2000-nél nagyobb kerceréce csoportokat.

Az év végi teljes balatoni felméréseink (KovÁcs, 2008c; 2008d; 2008e) során számolt három bukórécefaj megoszlását összehasonlítva, minden év szignifikánsan eltért egymástól $\left(\chi^{2}=13,5-59,8 ; \mathrm{p} \leq 0,001\right)$. A bukórécefajok állományának ingadozását már KEVE (1983) is megfigyelte, de empirikus közlését statisztikailag nem támasztotta alá.

Búbos vöcsökből gyakran csak néhány tíz egyed fordult elő a déli parton, de összességében állománya százas nagyságrendủ (max. 265 pld) volt. A teljes Balatonra vonatkozóan BANKOVICS (1985) hasonló adatokat (max. 225 pld) említett, ugyanakkor NAGY et al., (2008) (318-569 pld) és KovÁcs (2008c; 2008e) (506-620 pld) jelen dolgozat eredményeivel korreláló állománynagyságot állapított meg. Partszakaszonként általában néhány példány, de a tavaszi és őszi gyülekezéskor 10-20-as csapatokban mutatkozott. KEVE (1973a) esetenként jóval nagyobb csoportokról írt, ami vizsgálataink során ritkán fordult elő.

A kárókatona jelentősége az utóbbi évtizedekben nőtt meg, így a korábbi publikációkban csupán eseti megfigyelésekről vagy föként csak a kis-balatoni fészkelöállományról (KEVE, 1973; 1978) lehet olvasni. NAGY et al., (2008) 2003-2007 között 1000-2400, KOVÁCS (2008e) 2007-ben 1000 példányra becsülte a balatoni állományt. Esetünkben kétszer számoltunk 1000 feletti egyedszámot, egyik alkalommal 5521 pld-t. A felmérések egyhatodában több százas állománya volt jelen. Ugyan a Kis-Balatonon és a Nagyberekben tekintélyes költóállománya van (KovÁCs et al., 2011), a Balaton életében az északról érkező telelőállomány mennyisége, így jelentősége is nagyobb.

A kis kócsag és a nagy kócsag balatoni állománya nem jelentős, a halastavakon jóval nagyobb számban fordult elő (KovÁCS, 2008c; 2008d; 2008e). Mindkét faj az alacsony vízállás idején jelent meg nagyobb számban, partközelben. Állományuk legfeljebb néhány tíz egyed, de inkább 10 alatti volt. NAGY et al., (2008) szinte megegyező állománynagyságot állapított meg a teljes Balatonon, vélhetően ezen fajok esetében a déli part bír a legnagyobb jelentőséggel. A nagy kócsagnak több nagyobb költőtelepe található a déli parti berkekben (Nagyberek, Forróárok berke, Balatonőszödi-berek, Tóközi-berek). A korábbi időszakokban mindkét faj ritka volt, így csak alkalomszerü megfigyelései voltak (KEVE, 1978).

A szárcsa a tőkés réce és a dankasirály mellett a harmadik legnagyobb számban elöforduló faj volt, jelentőségéröl és vándorkagyló-fogyasztásáról (Dreissena polymorpha) már KEVE (1972a; 1982) is beszámolt. A 2003-2004-es szezonban alig több mint 300-as állományát figyeltük meg, a következő években 1700-4000 pld-t számoltunk a déli parton. Balatoni állománya 3000-6700 (KovÁCS, 2008c; 2008d; 2008e), illetve 4800-7000 egyed (NAGY et al., 2008) körül alakult. BANKOVICS (1985) korábban nagyságrendileg hasonlóan becsülte, bár az 1983-as 11566 pld kétségtelen kiemelkedö adat, amelynek fényében KEVE (1972a) állománybecslése (10000-15000 pld) nem tünik túlzónak.

A vízimadarak mennyiségét tekintve a dankasirály volt a második a vizsgálat ideje alatt. Dél-balatoni állománya 1500-2100 pld volt, a szélsőséges években 500, illetve 6700 pld. BANKOVICS (1985) 2000 pld körül, NAGY et al. (2008) 2200-3800 pld-nak adta meg a teljes tóra vonatkozó állománynagyságot. A Balaton egy pontján megfigyelhető nagyszámú csoportosulásáról számolt be KEVE (1972b), amelyet mi is tapasztaltunk, Szántódnál 1600 pld, Balatonszabadinál két különböző évben is, először 1830 pld, majd ennek több mint háromszorosa aggregálódott. 
A viharsirályból - hasonlóan KEVE (1972b), BANKOVICs (1985) és HAVRANEK et al. (1995) eredményeihez - keveset, 110-630 pld-t figyeltünk meg, míg NAGY et al. (2008) 8001900 pld közötti adatokat közölt.

A sárgalábú/sztyeppi sirály déli parti állománya 300-1500 pld volt, NAGY et al. (2008) az egész Balatonra vonatkoztatva hasonló 500-1500 pld-os értéket adott meg. KEVE (1972b), BANKOVICS (1985) és HAVRANEK et al. (1995) ennél kisebb mennyiségeket közölt.

A küszvágó csér dél-balatoni állománya 130-500 pld volt. NAGY et al. (2008) a balatoni állományra vonatkozóan szinte megegyező (130-550 pld) adatot publikált. A küszvágó csér mindig is a Balaton jellemző faja volt (KEVE, 1972b), bár fészkelési lehetőségei korlátozottak (KovÁCs, 2008f).

\subsection{A gyakori vízimadárfajok állományváltozása}

Az öt év során három gyakori faj esetében volt erőteljes állománynövekedés, melyek közül a búbos vöcsök és a szárcsa $p<0,05$, a kárókatona $p<0,1$ szinten volt szignifikáns. A nagy kócsag, a sárgalábú/sztyeppi sirály és a küszvágó csér állománya erős csökkenést mutatott $(p \leq 0,1)$. $A$ többi 10 fajnál egyértelmü (szignifikáns) trend nem volt megállapítható (6. táblázat).

Az egyes éveket összehasonlítva a trendet mutató fajokon kívül (kivéve kárókatona) (ANOVA $\mathrm{F} \geq 3,27 ; \mathrm{p} \leq 0,01$ ) további négy vízimadár esetében (kis kócsag, bütykös hattyú, tőkés réce, kanalas réce) adódtak szignifikáns eltérések (ANOVA $\mathrm{F} \geq 2,97 ; \mathrm{p} \leq 0,02$ ) az állománynagyságokban.

A dél-balatoni eredményeket tágabb kontextusba helyezve egybevetettem a hazai és nemzetközi (AEWA régió) vizes élőhelyeken tapasztalt viszonyokkal.

6. táblázat: A gyakori vízimadárfajok állományváltozási trendjei az éves változás (slope) alapján és az átlagállományok szezonkénti összehasonlítása (ANOVA) a Balaton déli

partján és Magyarországon (Magyar Vízivad Monitoring) 2003-2008 között

Table 6: Population trends of common waterbird species according annual change (slope) and the seasonal comparison of the average population (ANOVA) species on the southern shore of Lake

Balaton and in Hungary (Hungarian Waterfowl Monitoring) between 2003-2008

$\left(* \mathrm{p}=0,1 ; * *_{\mathrm{p}}=0,05 ; * * * \mathrm{p}=0,01\right)$

\begin{tabular}{|c|c|c|c|c|c|c|c|c|c|c|}
\hline \multirow{2}{*}{$\begin{array}{c}\mathbf{F a j} \\
\text { Species }\end{array}$} & \multicolumn{3}{|c|}{ Dél-Balatoni (South-Balaton) trend } & \multicolumn{2}{|c|}{ ANOVA } & \multicolumn{3}{|c|}{ Magyarországi (Hungarian) trend } & \multicolumn{2}{|c|}{ ANOVA } \\
\hline & Slope $(\%)$ & $\pm \mathbf{S E}$ & Irány/Classification & $\mathbf{F}$ & $\mathbf{p}$ & Slope $(\%)$ & $\pm \mathbf{S E}$ & Irány/Classification & $\mathbf{F}$ & $\mathbf{p}$ \\
\hline PODTUS & $* * 181,7$ & 49,5 & erös növ./strong inc. & 4,32 & 0,002 & 3,5 & 2,9 & bizonytalan/uncertain & 0,24 & 0,91 \\
\hline PHACAR & $* 34,8$ & 13,1 & erős növ./strong inc. & 1,00 & 0,41 & $* *-7,0$ & 1,9 & erös csökk./steep decl. & 1,12 & 0,34 \\
\hline EGRGAR & $-15,3$ & 10,8 & bizonytalan/uncertain & 6,17 & 0,000 & & & & & \\
\hline EGRALB & $*-18,4$ & 9,0 & erős csökk./steep decl. & 11,04 & 0,000 & $* * 5,6$ & 1,3 & mérs. növ./mod. inc. & 0,35 & 0,84 \\
\hline CYGOLO & 3,1 & 21,7 & bizonytalan/uncertain & 7,80 & 0,000 & 5,6 & 4,4 & bizonytalan/uncertain & 4,56 & 0,001 \\
\hline ANSANS & $-15,6$ & 11,0 & bizonytalan/uncertain & 0,34 & 0,85 & $* *-8,1$ & 2,6 & erös csökk./steep decl. & 0,84 & 0,50 \\
\hline ANAPLA & $-11,3$ & 7,2 & bizonytalan/uncertain & 8,12 & 0,000 & $-3,9$ & 9,7 & bizonytalan/uncertain & 1,99 & 0,09 \\
\hline ANACLY & $-27,5$ & 17,8 & bizonytalan/uncertain & 2,97 & 0,02 & $-0,7$ & 8,6 & bizonytalan/uncertain & 0,90 & 0,46 \\
\hline AYTFER & 13,7 & 11,7 & bizonytalan/uncertain & 0,57 & 0,69 & 2,5 & 8,3 & bizonytalan/uncertain & 2,37 & 0,05 \\
\hline AYTFUL & $-6,9$ & 44,3 & bizonytalan/uncertain & 0,70 & 0,59 & 1,0 & 7,6 & bizonytalan/uncertain & 0,79 & 0,53 \\
\hline BUCCLA & $-1,2$ & 7,3 & bizonytalan/uncertain & 0,20 & 0,94 & $-10,0$ & 6,3 & bizonytalan/uncertain & 0,59 & 0,67 \\
\hline FULATR & $* * * 104,2$ & 17,4 & erős növ./strong inc. & 3,40 & 0,009 & 10,2 & 7,3 & bizonytalan/uncertain & 1,50 & 0,20 \\
\hline LARRID & $-7,0$ & 9,9 & bizonytalan/uncertain & 1,21 & 0,31 & & & & & \\
\hline LARCAN & $-7,9$ & 13,9 & bizonytalan/uncertain & 0,66 & 0,62 & & & & & \\
\hline LARCAC & $*-16,1$ & 5,4 & erős csökk./steep decl. & 8,45 & 0,000 & & & & & \\
\hline STEHIR & $*-14,9$ & 7,0 & erős csökk./steep decl. & 3,27 & 0,01 & & & & & \\
\hline
\end{tabular}


A Magyar Vízivad Monitoring ugyanezen időszakra vonatkozó adatai alapján (FARAGÓ, 2006b; 2007b; 2007d; 2008b; 2010b) általánosságban elmondható, hogy a változások mértéke kisebb, illetve több esetben ellentétes (6. táblázat). A kárókatona és a nyári lúd esetében az országos trend erősen csökkenő, míg a nagy kócsagnál mérsékelt növekedés $(\mathrm{p} \leq 0,05)$ látható. A többi fajnál a változás iránya bizonytalan volt. Ezek alapján a búbos vöcsök, a kárókatona és a szárcsa dél-balatoni erőteljes állománynövekedése, a nagy kócsag állomány erős csökkenése csupán lokális trendnek tekinthető. A nagy kócsag esetében fontos megemlíteni, hogy a dél-balatoni berkekben stabil fészkelöállománya van. Jellemzően télen is megfigyelhető, így a számára kedvezö élőhelyeken (berkek, halastavak) - az országos viszonyokhoz hasonlóan - egyre jelentősebb számban fordult elő. A vizsgált partszakaszokon az alacsony vízállás idején jelentek meg, majd a vízszint emelkedésével, a kedvező táplálkozóhelyeik megszűnésével elmaradtak.

\section{7. táblázat: A gyakori vízimadárfajok populációinak rövidtávú (2003-2007) állományváltozási trendjei (lineáris regresszióval és TRIM szoftverrel) az AEWA régióban $(* \mathrm{p}=0,1 ; * * \mathrm{p}=0,05 ; * * * \mathrm{p}=0,01)$}

Table 7: Short term (2003-2007) population trends of common waterbirds species in AEWA region (linear regression and TRIM output)

\begin{tabular}{|c|c|c|c|c|c|}
\hline \multirow{2}{*}{ AEWA populáció } & \multicolumn{2}{|c|}{ Lin. regr. trend } & \multicolumn{3}{|c|}{ TRIM output } \\
\hline & Slope $(\%)$ & $\pm \mathbf{S E}$ & Slope $(\%)$ & \pm Konf. & Irány/Classification \\
\hline $\begin{array}{l}\text { Podiceps cristatus cristatus } \\
\text { Északnyugat- \& Nyugat-Európa }\end{array}$ & 2,8 & 4,4 & 2,6 & 1,4 & $\begin{array}{l}\text { mérsékelt növ.l } \\
\text { moderate inc. }\end{array}$ \\
\hline $\begin{array}{l}\text { Phalacrocorax carbo sinensis } \\
\text { Nyugat- \& Közép-Európa }\end{array}$ & $-0,5$ & 2,7 & $-0,4$ & 1,9 & $\begin{array}{l}\text { bizonytalan/ } \\
\text { uncertain }\end{array}$ \\
\hline $\begin{array}{l}\text { Casmerodius albus albus (Egretta alba alba) } \\
\text { Ny-, Közép- \& Dk-Európa/Fekete-tenger \& Mediterráneum }\end{array}$ & $* * * 19,6$ & 2,2 & 15,3 & 3,5 & $\begin{array}{l}\text { erős növ./ } \\
\text { strong inc. }\end{array}$ \\
\hline $\begin{array}{l}\text { Egretta garzetta garzetta } \\
\text { Nyugat-Európa, Ėszaknyugat-Afrika }\end{array}$ & 0,8 & 4,3 & 0,7 & 2,6 & $\begin{array}{l}\text { bizonytalan/ } \\
\text { uncertain }\end{array}$ \\
\hline $\begin{array}{l}\text { Cygnus olor } \\
\text { Északnyugati kontinens \& Közép-Európa }\end{array}$ & $-1,1$ & 4,9 & $-1,5$ & 1,4 & $\begin{array}{l}\text { mérs. csökk./ } \\
\text { mod. dec. }\end{array}$ \\
\hline $\begin{array}{l}\text { Anser anser anser } \\
\text { Északnyugat-Európa/Délnyugat-Európa }\end{array}$ & $* 9,9$ & 4,4 & 8,4 & 2,0 & $\begin{array}{l}\text { erős növ./ } \\
\text { strong inc. }\end{array}$ \\
\hline $\begin{array}{l}\text { Anas platyrhynchos platyrhynchos } \\
\text { Nyugat-Európa/Nyugat-Mediterráneum }\end{array}$ & 2,4 & 3,9 & 2,2 & 1,6 & $\begin{array}{l}\text { mérsékelt növ./ } \\
\text { moderate inc. }\end{array}$ \\
\hline $\begin{array}{l}\text { Anas clypeata } \\
\text { Északnyugat- \& Közép-Európa (telelö) }\end{array}$ & $* * 11,8$ & 2,5 & 9,7 & 2,3 & $\begin{array}{l}\text { erős növ./ } \\
\text { strong inc. }\end{array}$ \\
\hline $\begin{array}{l}\text { Aythya ferina } \\
\text { Közép- \& Ék-Európa/Fekete-tenger \& Mediterráneum }\end{array}$ & $*-2,9$ & 1,3 & $-6,0$ & 3,0 & $\begin{array}{l}\text { erős csökk./ } \\
\text { steep decl. }\end{array}$ \\
\hline $\begin{array}{l}\text { Aythya fuligula } \\
\text { Közép-Európa, Fekete-tenger \& Mediterráneum (telelő) }\end{array}$ & $* * *-4,3$ & 0,2 & $-4,7$ & 2,2 & $\begin{array}{l}\text { mérs. csökk./ } \\
\text { mod. dec. }\end{array}$ \\
\hline $\begin{array}{l}\text { Bucephala clangula clangula } \\
\text { Északnyugat- \& Közép-Európa (telelö) }\end{array}$ & 1,7 & 1,7 & 1,6 & 2,0 & $\begin{array}{l}\text { bizonytalan/ } \\
\text { uncertain }\end{array}$ \\
\hline $\begin{array}{l}\text { Fulica atra atra } \\
\text { Fekete-tenger \& Mediterráneum (telelő) }\end{array}$ & $* * 8,6$ & 2,7 & 7,3 & 3,1 & $\begin{array}{l}\text { erős növ./ } \\
\text { strong inc. }\end{array}$ \\
\hline $\begin{array}{l}\text { Larus canus canus } \\
\text { Ény- \& Közép-Európa/Atlanti partvidék \& Mediterráneum }\end{array}$ & 3,7 & 6,6 & 3,9 & 2,3 & $\begin{array}{l}\text { mérsékelt növ./ } \\
\text { moderate inc. }\end{array}$ \\
\hline $\begin{array}{l}\text { Larus ridibundus } \\
\text { Kelet-Európa/Fekete-tenger \& Kelet-Mediterráneum }\end{array}$ & 11,8 & 7,5 & 10,5 & 9,8 & $\begin{array}{l}\text { erős növ./ } \\
\text { strong inc. }\end{array}$ \\
\hline
\end{tabular}

A nemzetközi kitekintéshez az adott rövid távú idöszakra (2003-2007) vonatkozóan az AEWA populációkra létezik trendelemzés (WETLANDS INTERNATIONAL \& SOVON, 2011). Mivel az adatok kiértékelése a TRIM szoftverrel (PANNEKOEK \& STRIEN, 2001) készült, ezért emellett az általam alkalmazott módszerrel (lineáris regresszió) is elvégeztem a számításokat (7. táblázat). Sajnos a búbos vöcsök, a kis kócsag, a nyári lúd és a kerceréce esetében a hazai 
állományoknak megfelelő AEWA populációkra vonatkozóan nem állnak rendelkezésre elemzések, így itt a fajok más populácóit vettem viszonyítási alapnak. Nemzetközi összehasonlításban csupán a búbos vöcsök és a szárcsa mutatott a dél-balatonihoz hasonló trendet. A kis kócsag és a kerceréce esetében mindkét elemzésben bizonytalan volt a trend iránya. A nagy kócsagnál a hazai viszonyoknak megfelelően erős növekedés volt jellemző az AEWA populációra, ami ellentétes volt a dél-balatonival. További öt faj (nyári lúd, tőkés réce, kanalas réce, viharsirály, dankasirály) trendje növekedö, három fajnak (bütykös hattyú, barátréce, kontyos réce) pedig csökkenő volt, míg ugyanezen vízimadarak trendje a DélBalatonnál bizonytalanak minősíthető. Mindazonáltal a kárókatona állományának erőteljes lokális növekedése nem volt jellemző a faj nyugat-, közép-európai populációjának egészére.

\subsection{A gyakori vízimadárfajok fenológiája}

A jelentősebb csoportokat, fajokat tekintve a vöcskök dinamikáját elsősorban a búbos vöcsök határozta meg, hiszen a családon belül megfigyelt egyedek több mint 99\%-át adta. Ennek folyományaként egy áprilisi és egy októberi állománycsúcs állapítható meg, egybevágóan KEVE (1973) dolgozatával; nyáron viszont igen kis számban fordultak elö.

A kárókatonák esetében a kis kárókatona egyedszáma meglehetősen alacsony volt $(0,2 \%)$, így a taxonnal kapcsolatos megállapításokat elsősorban a kárókatonáról lehet megtenni. Állománya decemberben éri el a csúcsát, de egy kisebb tavaszi gyülekezés is megfigyelhetö volt, utóbbi HAVRANEK et al. (1995) munkájában is olvasható. Az irodalmi adatok (KEVE, 1973) szerint az 1970-es évekig februártól novemberig fordult elö, a nagyszámú téli előfordulás nem volt jellemző.

Az év kétharmadában az Anatidae család egyedeinek aránya 40\% felett volt, számuk a többi vízimadárhoz képest ősztől tavaszig jelentősen megnövekedett (50. ábra). A bütykös hattyú a déli parton a legnagyobb tömegben a vedlés időszakában jelent meg, ahogy a Balaton egészén, a nyár vége-ősz a legjelentősebb periódus (SZINAI, 1997; 1998; ALBERT et al., 2004).

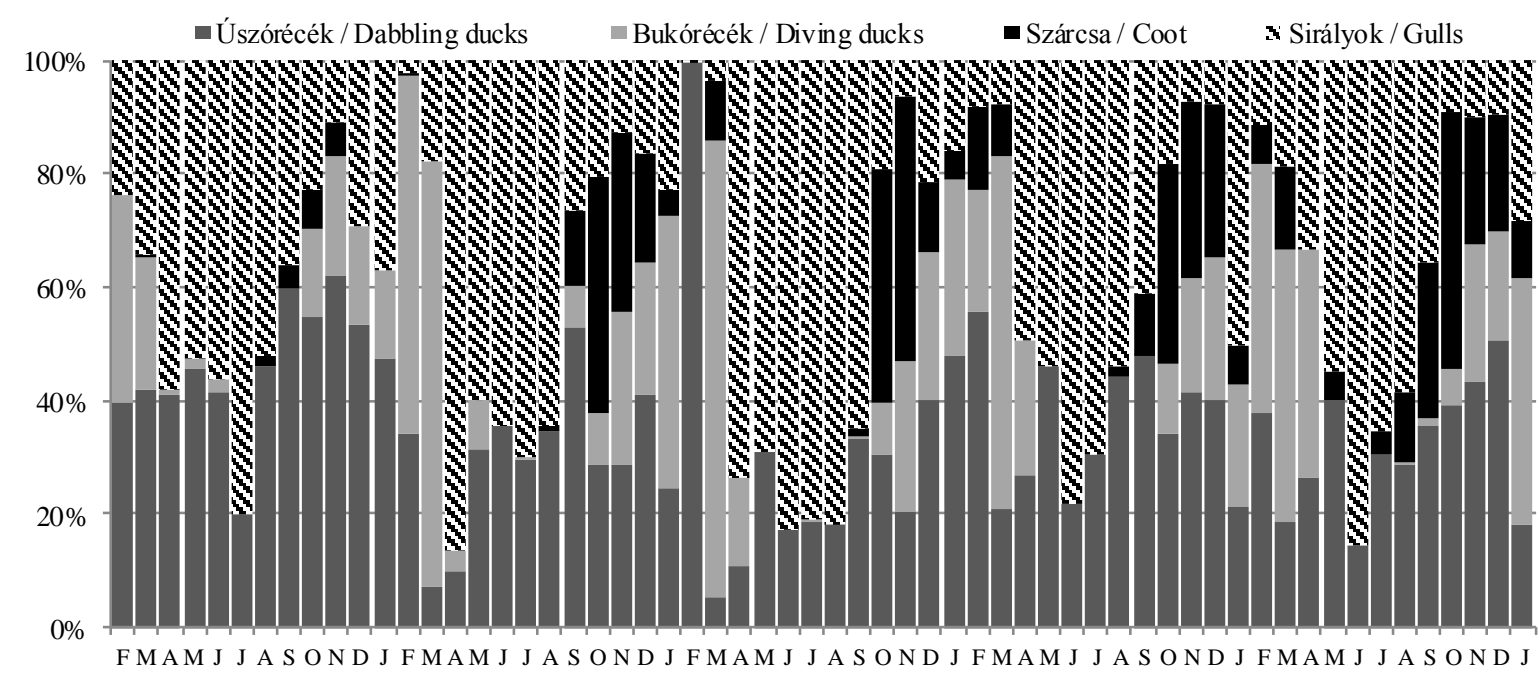

50. ábra: A gyakori vízimadár csoportok megoszlása az egyes hónapokban a Balaton déli partján (2003-2008)

Figure 50: Distribution of common waterbird groups in each month on the southern shore of Lake Balaton (2003-2008)

A bukó- és úszórécék fenológiájában némi különbség fedezhető fel. Utóbbiak ősztől kora tavaszig tartózkodnak nagy tömegben a Balatonon, és tavasztól kora őszig csupán néhány egyed 
látható. Az úszórécék jelenléte ezzel szemben sokkal kiegyenlítettebb volt, bár a nagyobb csoportosulások szintén az őszi vonulás és a telelés időszakára tehetők. A két csoport időbeli eloszlásában, illetve a csúcsokban néhány hónapos eltolódás figyelhető meg, ugyanakkor a csúcs 2005-2006 telén egymásba torlódott, majd a következő télen teljesen fedésbe került (51. ábra), hasonlóan NAGY et al. (2008) teljes balatoni felméréseihez. A bukórécéken belül a három gyakori faj esetében KEVE (1968), majd BANKOVICS (1985; 1997) a kerceréce kulminációjára ősszel november közepét, december első felét, tavaszra február második felét jelölte meg; a barátrécénél szeptembert (néha november) és február-márciust (április); míg a kontyos récénél novembert és március második felét, áprilist. Jelen vizsgálatban a kerceréce január, március (egy-egy évben november, december); a barátréce és a kontyos réce november, március hónapokban érte el az állománycsúcsát (52. ábra). Összességében a bukórécéknél egy kisebb novemberi (decemberi), majd egy nagyobb márciusi (januári) csúcs volt megfigyelhető. Mivel az úszórécék több mint 97\%-a tőkés réce volt, így a fajjal jól jellemezhető az egész csoport. A gyülekezés csúcsai szeptember, december, valamint november, január hónapokban voltak (51. ábra). BANKOVICS (1985) szintén januárban számolta a legnagyobb (tízezres) tőkés réce csapatokat, majd később októberi (BANKOVICS, 1997), míg korábban KEVE (1970a) októberi, novemberi, illetve márciusi kulminálásról írt. Mind a bukó-, mind az úszórécék esetében NAGY et al. (2008) egész Balatonra vonatkozó vizsgálataiban lényeges eltérés nem volt.

A szárcsa esetében a nagyobb tömegek októberben és novemberben voltak, ahogy évtizedekkel korábban KEVE (1972a; 1982), illetve BANKOVICS (1985) vizsgálataiban. Nagyszámú megjelenése többé-kevésbé a bukórécék gyülekezésének idejére tehető, esetenként egy-egy hónapos csúszással (51. ábra). Érdekes, hogy az első évben az átlagoshoz képest csak kis mennyiségben figyeltük meg. NAGY et al. (2008) balatoni, kis-balatoni és a környező halastavakra kiterjedő felmérései alapján a telelőállomány $90 \%$-a a Balatonon koncentrálódott az összes vizesélőhely közül, esetünkben ez az arány 92-98\% között volt (KovÁCS, 2008c; 2008d; 2008e).

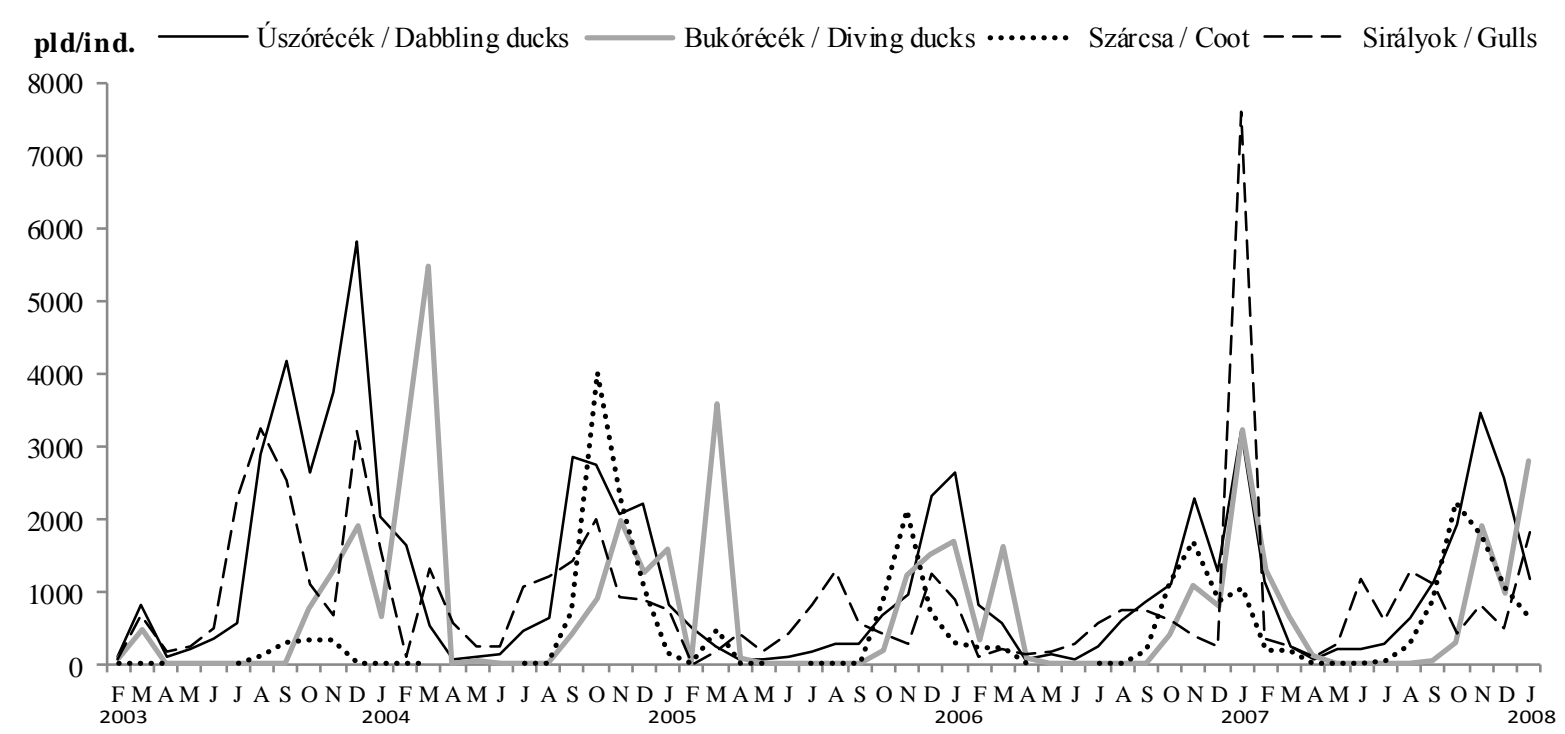

51. ábra: A gyakori vízimadár csoportok dinamikája a Balaton déli partján (2003-2008)

Figure 51: Dynamics of common waterbird groups on the southern shore of Lake Balaton (20032008)

A sirályok közül a dankasirály éves kulminációja nem teljesen egyértelmüen meghatározható, jellemzően azért kora ősszel lehetett nagyobb tömegben látni. Kiugróan nagy számban, közel 7000 pld jelent meg 2007 januárjában, ami meglepően szokatlan, föként a télen. 
A régebbi publikációkból (KEVE, 1972b; BANKOVICS, 1985) elsősorban késő őszi, illetve nagyszámú téli gyülekezésekről is lehetett olvasni. A viharsirály a korábbi megfigyelésekhez hasonlóan (KEVE, 1972b) ősztől tavaszig fordult elő. Állománya december, januárban érte el maximumait, hasonlóan BANKOVICS (1985) adataihoz. A sárgalábú/sztyeppi sirály főként nyár végén, augusztusban jelent meg legnagyobb számban, KEVE (1972b) szerint augusztusban volt tömeges. Mindenesetre a minimum február, márciusra esett, ahogy a korábbi évtizedekben is (KEVE, 1972b). Összességében a sirályokra a nyárvégi és téli kulmináció, valamint kora tavaszi, tavaszi minimum jellemző (51. ábra).

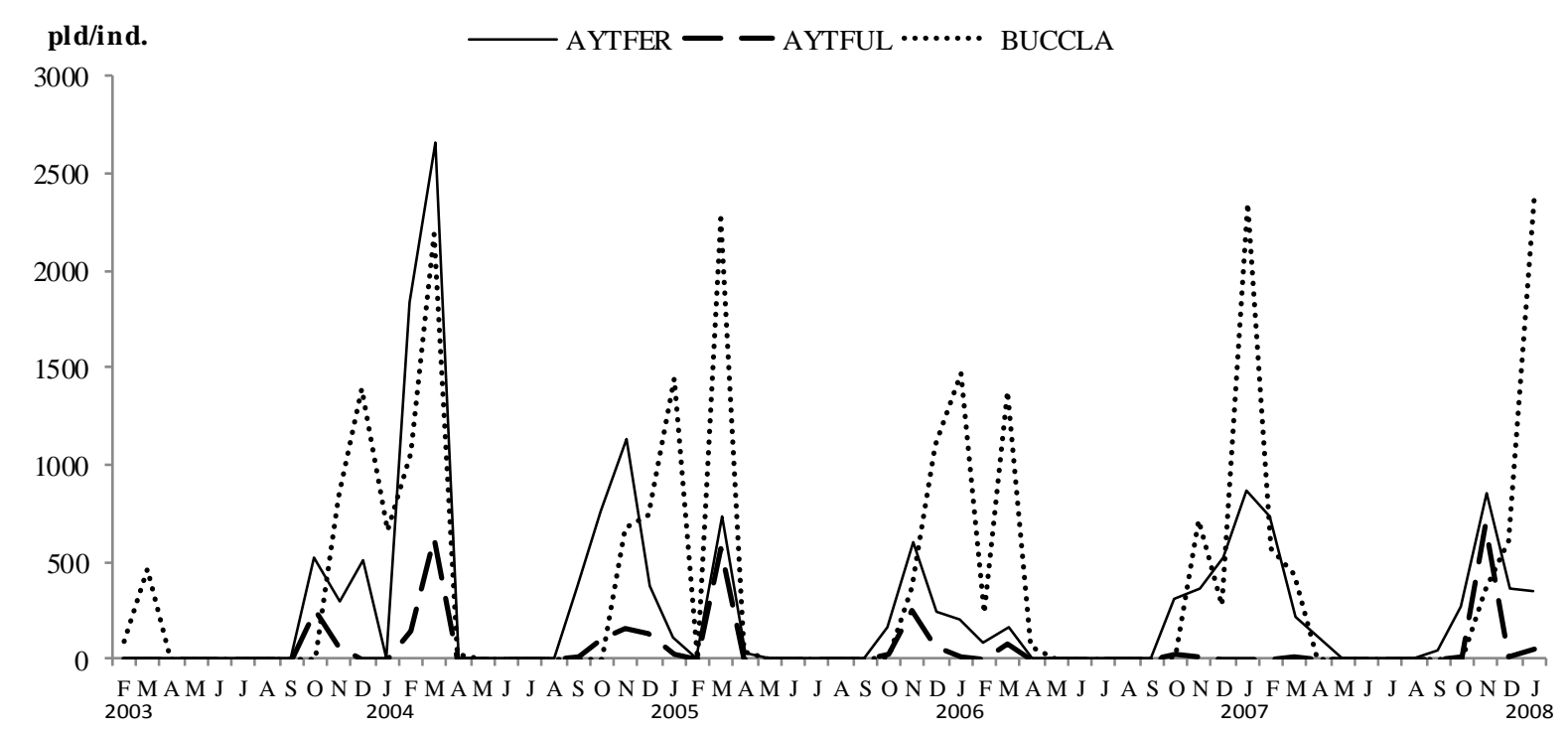

52. ábra: A három gyakori bukórécefaj (barátréce, kontyos réce, kerceréce) dinamikája a Balaton déli partján (2003-2008)

Figure 52: Dynamics of 3 common diving ducks (Pochard, Tufted Duck, Goldeneye) on the southern shore of Lake Balaton (2003-2008)

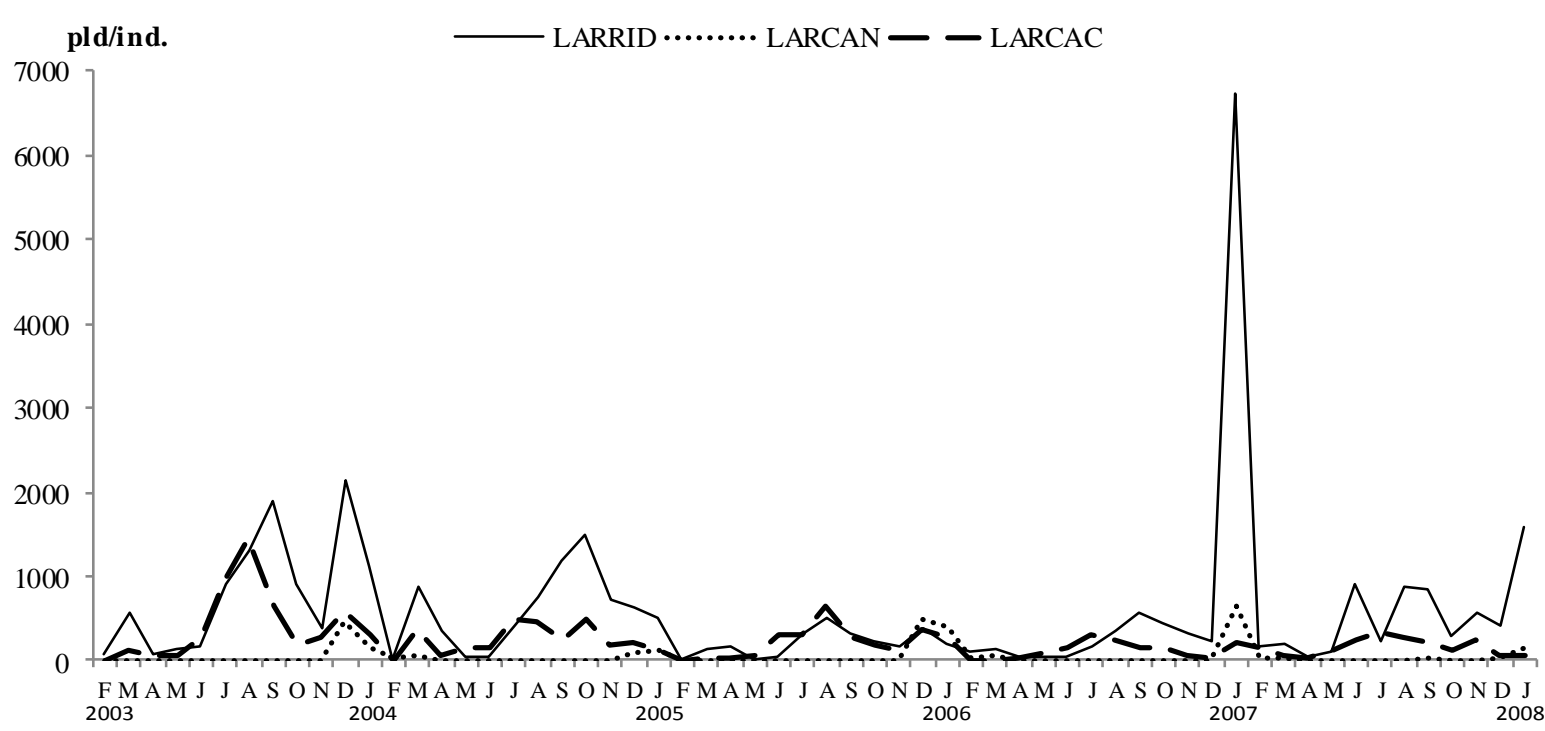

53. ábra: A három gyakori sirályfaj (dankasirály, viharsirály, sárgalábú/sztyeppi sirály) dinamikája az egyes hónapokban a Balaton déli partján (2003-2008)

Figure 53: Dynamics of 3 common gulls (Black-headed Gull, Mew Gull, Yellow-legged/Caspian Gull) on the southern shore of Lake Balaton (2003-2008) 
A megfigyelt csérek 98,4\%-a küszvágó csér volt. KEVE (1972b) tapasztalatai alapján a tavaszi gyülekezés április-májusban, az őszi augusztus-szeptemberben történik. A fajjal kapcsolatos előfordulási és fészkelési adatokat korábban már feldolgoztam (KovÁCs, 2008f), itt csak röviden foglalom össze. Esetünkben a tavaszi csúcs időpontja, megegyezik, de főként áprilisra tehető. A költés utáni tömeges megjelenés július-augusztusban volt. A vizsgált időpontban jellemzően áprilistól szeptemberig (márciusban egy alkalommal) fordult elö, KEVE (1972b) 1946-1971 között szintén csupán egyszer figyelte meg márciusban, illetve októberben.

\subsection{A szórványos vízimadárfajok értékelése}

A szórványos és ritka fajok között számos védett és fokozottan védett vízimadár került elő, amelyek nemcsak lokálisan és regionálisan, hanem országosan is figyelemre tarthatnak számot. Mivel a ritka fajok esetében kis egyedszámokról van szó, ezért ezek külön értékelésétől eltekintek, az eredményekben történt felsorolása faunisztikai szempontból érdekes.

A KeVe (1978), Sterbetz (1975), BANKOVICs (1985), HAVRANEK et al. (1995) és HAVRANEK (1996b) által említett több ezres nagy lilik, illetve több tízezres vetési lúd csapatokhoz hasonlót nem figyeltük meg a Balatonon, legfeljebb néhány száz egyeddel találkoztunk mindkét fajból, igaz az általunk alkalmazott felmérési módszer nem is felel meg a ludak állománybecslésére. NAGY et al., (2008) is csak két szezonban számoltak 2000-nél több nagy liliket a tavon. A Magyar Vadlúd Monitoring (FARAGÓ, 2005a; 2006a; 2007a; 2007c; 2008a; 2010b) eredményei alapján az utolsó két szezonban a Balatonon csökkent a vetési lúd és a nagy lilik aránya a nyári lúdhoz képest, hasonló volt a megoszlás a három lúdfaj között a teljes Balatonon végzett év végi felméréseken (KovÁcs, 2008d; 2008e) is.

A szórványos úszórécefajok állománya általában nem érte el a százat a csörgő réce kivételével. NAGY et al., (2008) nagyságrendileg hasonló állománynagyságokat közölt, ami alapján megállapítható, hogy ezen fajok elsősorban a déli parton fordultak elő. KEVE (1970a) két évtizedes megfigyelései alapján mindegyik szórványos úszórécefajból beszámolt 100 példány feletti csapatokról. Míg az 1980-as évek első felében (BANKOVICS, 1985) és az ezredforduló után kizárólag a csörgő réce esetében lehetett megfigyelni több százas csapatokat, addig a 20. század közepén még a böjti réce is hasonló mennyiségben fordult elö a Balatonon KEVE (1970a). A bukórécék közül az üstökös réce és a hegyi réce tekinthető szórványosnak. Mindkét faj állománya jellemzően tízes nagyságrendü, utóbbi 2005 decemberében elérte a százat. NAGY et al., (2008) ugyanilyen állománynagyságokat adott meg, jellemzően tehát ezek a fajok is a déli parton fordultak elö. A hegyi récét KEVE $(1968,1983)$ is rendszeresen megfigyelte kis egyedszámban, ugyanakkor az üstökös récéröl még nem írt. BANKOVICS (1985), HAVRANEK et al. (1995) és HAVRANEK (1996a) is ritka fajként említette az üstökös és a hegyi récét egyaránt. A kis bukóból 10 alattit figyeltünk meg egyszerre, NAGY et al., (2008) 20-50 pld-t adott meg a teljes Balatonra, hasonló mennyiségeket közölt KEVE (1968) és HAVRANEK et al. (1995).

A sarki búvár korábban is rendszeresen megfigyelhető volt, rendszerint magános példányok, ritkábban néhány egyed egy helyen, jellemzően az év végi hónapokban (LovASSY, 1897; KEVE, 1973). A mi megfigyeléseink ezzel azonosak voltak, mindazonáltal az öt év alatt erős és szignifikáns növekedés volt tapasztalható. NAGY et al., (2008) adatai alapján is az utolsó szezonban volt a legtöbb megfigyelés.

A vizsgált időszakra tehető a kis kárókatona Nagyberekben való megjelenése és első költése. Ennek megfelelően korábban az egyes szerzők (KEVE, BANKOVICS, HAVRANEK) nem említik. Azóta állománya itt megerösödött, előfordulása inkább a halastavakon, berkekben jellemző. NAGY et al., (2008) - a második év kivételével - nagyjából azonos számban (12-19 
pld) figyelte meg. A déli parton az első időszak ritka előfordulásai után (1-4 pld) az utolsó szezonban jelent meg némileg több egyed (1-10 pld).

A kócsagokhoz hasonlóan a szürke gém Balaton-parti állománya sem jelentős, a halastavakon és berkekben jóval nagyobb számban fordult elő (KovÁCs, 2008c; 2008d; 2008e), ahol költ is. A faj korábban is jellemző volt kis számban (KEVE, 1978; HAVRANEK 1996a). A szürke gém szintén az alacsony vízállás idején jelent meg, partközelben, de kisebb számban, mint a kócsagok. Állománya erősen (szignifikánsan) csökkent az öt év alatt, ami a vízszint emelkedésével és ennek következtében a kedvező táplálkozási feltételek megszunnésével függhet össze. NAGY et al., (2008) az első időszakban kevesebbet, a vizsgálatuk végén jóval többet figyeltek meg, esetükben a tendencia fordított volt. Feltételezhetően itt egyszeri nagyobb számú előfordulás lehetett.

A rétisast 20. század közepén ritkán lehetett megfigyelni, általában csak 1-1 példány került szem elé (KEVE, 1978). Még az 1980-as években BANKOVICS (1985) is csak egyszer látta 17 megfigyelőnapon. Azóta lényegesen jobb a helyzet, a rétisas állománya egész Magyarországon megerősödött, a Dél-Balatonon (Nagyberek, Balatonszemes) költ. A téli időszakban - a halastavak, berkek mellett - a Balatonon is rendszeresen megfigyelhetö, jellemzően akkor, amikor jég borítja a tavat. Az itt elöforduló példányok között nemcsak helyi költők, hanem északról érkezők is voltak.

A parti madarak közül két fajt érdemes megemlíteni. Míg a piroslábú cankó csak az első két szezonban fordult elő, addig a billegetőcankó minden évben megjelent, igaz az utolsó három szezonban előfordulása 1-1 példányra korlátozódott. NAGY et al., (2008) piroslábú cankóból 24 egyedet közöltek, azt is a második, harmadik szezonból. Esetükben a billegető cankóból ellentétesen a mi adatainkkal - egyre többet figyeltek meg. A két faj élőhelyhasználata jól elkülönült. Az előbbi teljes mértékben kötődik az alacsony vízállás idején kialakult fövenyekhez, tocsogókhoz. A billegetőcankó ezek mellett és később is a parti kövezéseken jelent meg, ami a normál és magas vízszint idején is rendelkezésre állt. Ezt megerősíti KEVE (1978) korábbi dolgozat.

Az ezüstsirály előfordulások összevetése a korábbi adatokkal gyakorlatilag nem lehetséges, hiszen korábbi publikációkban nem volt pontos taxonómiai elkülönítése a sárgalábú, illetve a szteppi sirálytól (KEVE, 1972b). Ugyanakkor korábban is megjelent a faj a Balatonon, amit KEVE \& PÁTKAI (1955) múzeumi példányok - akkor alfaji szinten történt határozásával bizonyított. Mivel a faji szintü határozás a vizsgálat kezdetén vált gyakorlattá, ezért a megfigyelési adatokat többször felülbíráltam GÁL SzABOLCS javaslatára. Bár kevesebbet figyeltünk meg, ugyanakkor csökkenő trendje egybevág NAGY et al., (2008) közlésével.

A jégmadár időnként megfigyelhető, de korábban sem volt gyakori (KEVE, 1978). Az egész déli parton általában néhány egyedet (max. 3 pld) figyeltünk meg. Míg NAGY et al., (2008) a teljes Balatonra 4-5 példányt adott meg, addig a novemberi szintén teljes balatoni felméréseinken 11-2-6 egyedet számoltunk (KovÁCS, 2008c; 2008d; 2008e).

Összeségében megállapítható, hogy a 2003-2008 közötti déli-parti felmérés átfogó képet adott a Balaton madárvilágáról, illetve a fontosabb vízimadárfajok állományának rövidtávú változásáról. A vizsgálatokat feltétlenül érdemes folytatni, illetve az elemzéseket hosszabb időtávon elvégezni.

\section{KÖSZÖNETNYILVÁNÍTÁS}

Szeretném megköszönni a felmérők áldozatos munkáját, a kollégáim szakmai segítségét, feleségem és szüleim támogatását! A dolgozatot KEVE ANDRÁs emlékének ajánlom, tisztelegve inspiráló munkássága előtt. 


\section{IRODALOMJEGYZÉK}

Albert L., HAJTÓ L. \& SzINAI P. (2004): Status of the Mute Swan (Cygnus olor) in Hungary at the beginning of the 21th century [A bütykös hattyú (Cygnus olor) helyzete Magyarországon az ezredforduló tájékán]. Aquila 111: 19-41.

ANONYM (1970): A Nemzetközi Madárvédelmi Bizottság európai szakosztályának IX. konferenciája. Balatonszemes, 1968. május 15-19. Aquila 76-77: 11-26.

BANKOVICS A. (1985): A Balaton átvonuló és telelő vízimadarainak állománybecslése. Aquila 92: $55-64$.

BANKOVICS A. (1997): Data on some passage migrant Anatids at the Lake Balaton. Miscellanea Zoologica Hungarica 11: 89-94.

BIRDLIFE INTERNATIONAL (2004): Birds in the European Union: a status assessment. Wageningen, The Netherlands: BirdLife International. 50 p.

FARAGÓ S. (1996): A Magyar Vadlúd Adatbázis 1984-1995: egy tartamos monitoring. Magyar Vizivad Közlemények 2: 3-168.

FARAGÓ S. (1997): A Magyar Vízivad Információs Rendszer. Magyar Vizivad Közlemények 4: $3-16$.

FARAGÓ S. (1998a): A vadlúd monitoring eredményei az 1996/1997-es idényben Magyarországon. Magyar Vízivad Közlemények 4: 17-60.

FARAGÓ S. (1998b): A Magyar Vízivad Monitoring eredményei az 1996/1997-es idényben. Magyar Vizivad Közlemények 4: 61-263.

FARAGÓ S. (1999a): A Magyar Vízivad Monitoring eredményei az 1997/1998-as idényben. Magyar Vizivad Közlemények 5: 63-327.

FARAGÓ S. (1999b): A vadlúd monitoring eredményei az 1997/1998-as idényben Magyarországon. Magyar Vízivad Közlemények 5: 3-62.

FARAGÓ S. (2001a): A vadlúd monitoring eredményei az 1998/1999-es idényben Magyarországon. Magyar Vízivad Közlemények 7: 3-40.

FARAGÓ S. (2001b): A Magyar Vízivad Monitoring eredményei az 1998/1999-es idényben. Magyar Vizivad Közlemények 7: 41-212.

FARAGÓ S. (2002a): A vadlúd monitoring eredményei az 1999/2000-es idényben Magyarországon. Magyar Vízivad Közlemények 8: 3-43.

FARAGÓ S. (2002b): A vadlúd monitoring eredményei a 2000/2001-es idényben Magyarországon. Magyar Vízivad Közlemények 9: 3-45.

FARAGÓ S. (2002c): A Magyar Vízivad Monitoring eredményei a 2000/2001-es idényben. Magyar Vizivad Közlemények 9: 47-249.

FARAGÓ S. (2005a): A vadlúd monitoring eredményei a 2002/2003-as idényben Magyarországon. Magyar Vízivad Közlemények 12: 3-42.

FARAGÓ S. (2005b): A Magyar Vízivad Monitoring eredményei a 2002/2003-as idényben. Magyar Vízivad Közlemények 12: 43-224.

FARAGÓ S. (2006a): A vadlúd monitoring eredményei a 2003/2004-es idényben Magyarországon. Magyar Vízivad Közlemények 13: 3-39.

FARAGÓ S. (2006b): A Magyar Vízivad Monitoring eredményei a 2003/2004-es idényben. Magyar Vízivad Közlemények 13: 41-214.

FARAGÓ S. (2007a): A vadlúd monitoring eredményei a 2004/2005-ös idényben Magyarországon. Magyar Vízivad Közlemények 14: 3-40.

FARAGÓ S. (2007b): A Magyar Vízivad Monitoring eredményei a 2004/2005-ös idényben. Magyar Vizivad Közlemények 14: 41-209.

FARAGÓ S. (2007c): A vadlúd monitoring eredményei a 2005/2006-os idényben Magyarországon. Magyar Vízivad Közlemények 15: 3-45. 
FARAGÓ S. (2007d): A Magyar Vízivad Monitoring eredményei a 2005/2006-os idényben. Magyar Vizivad Közlemények 15: 47-220.

FARAGÓ S. (2008a): A vadlúd monitoring eredményei a 2006/2007-es idényben Magyarországon. Magyar Vizivad Közlemények 17: 3-42.

FARAGÓ S. (2008b): A Magyar Vízivad Monitoring eredményei a 2006/2007-es idényben. Magyar Vízivad Közlemények 17: 43-214.

FARAGÓ S. (2010a): A vadlúd monitoring eredményei a 2007/2008-es idényben Magyarországon. Magyar Vízivad Közlemények 17: 3-41.

FARAGÓ S. (2010b): A Magyar Vízivad Monitoring eredményei a 2007/2008-as idényben. Magyar Vizivad Közlemények 18-19: 43-203.

FARAGÓ S. (2010c): A Magyar Vízivad Monitoring eredményei a 2008/2009-es idényben. Magyar Vizivad Közlemények 18-19: 259-420.

FARAGÓ S. (2010d): A vadlúd monitoring eredményei a 2008/2009-es idényben Magyarországon. Magyar Vizivad Közlemények 17: 221-258.

FARAGÓ S. \& GOSZTONYI L. (2002): A Magyar Vízivad Monitoring eredményei az 1999/2000es idényben. Magyar Vízivad Közlemények 8: 45-256.

FARAGÓ S. \& GoszTONYI L. (2003a): A vadlúd monitoring eredményei a 2001/2002-es idényben Magyarországon. Magyar Vízivad Közlemények 11: 3-50.

FARAGÓ S. \& GOSZTONYI L. (2003b): A Magyar Vízivad Monitoring eredményei a 2001/2002es idényben. Magyar Vizivad Közlemények 11: 51-252.

FARAGÓ S. \& JÁNOSKA F. (1996a): A szeptemberi nemzetközi nyári lúd (Anser anser) számlálás magyarországi eredményei 1989-1996. Magyar Vizivad Közlemények 2: 213-222.

FARAGÓ S. \& JÁNOSKA F. (1996b): A vadlúd monitoring eredményei az 1995/1996-os idényben Magyarországon. Magyar Vizivad Közlemények 2: 169-212.

Greenwood, J. J. D., Baillie, S. R., Crick, H. P. Q., Marchant, J. H. \& PeACH, W. J. (1993): Integrated population monitoring: detecting the effects of deverse changes. In: FURNESS R. W. \& GREENWOOD J. J. D. (eds.): Birds as monitors of environmental change. Chapman \& Hall, London. p. 267-328.

Hammer, Ø., HarPer, D. A. T. \& RyAn, P. D. (2001): PAST: Paleontological Statistics Software Package for Education and Data Analysis. Palaeontologia Electronica 4(1): $9 \mathrm{p}$.

HAVRANEK L. (1995): 1994. évi decemberi madárvonulás a Balatonon. Madártani Tájékoztató 1995. július-december: 28-29.

HAVRANEK L. (1996a): A Balaton déli partján előforduló vízimadarak 1995. Anser 2: 32-37.

HAVRANEK L. (1996b): Ludak (Anser) előfordulása a Balaton déli partján. Anser 2: 52-59.

HAVRANEK L. \& SzABÓ B. (1997): A Balaton és környéke madárfaunájának indexe. Anser 4: $10-49$.

HAVRANEK L., SZABÓ B. \& SzÁSZ S. (1995): Balatoni madárvonulások az 1991-1994. években. Anser 1: 12-28.

Homonnay N. (1940): A Balaton és környékének madarai. A Magyar Biológiai Kutatóintézet Munkái 12: 245-276.

IUCN (2012): IUCN Red List of Threatened Species. Version 2012.1. http://www.iucnredlist.org (letöltés: 2012.09.05.)

Kaupinnen, J., Koskimies, P. \& VÄIsÄnen, R. A. (1991): Waterfowl round count. In: Koskimies, P. \& Väisänen, R. A. (ed). Monitoring Bird Populations. Zoological Museum-Finnish Museum of History - University of Helsinki, Helsinki. p. 45-51.

KEVE A. (1968): Aythynae és Merginae-fajok előfordulása és vonulásuk évi ciklusai a Balatonon. Aquila 75: 21-44.

Keve A. (1970a): A Balaton úszórécéi (Anas sp.). Aquila 76-77: 117-139. 
KeVE A. (1970b): Über die Limikolen der Umgebung des Balaton-Sees. Beiträge zur Vogelkunde 16: 219-231.

Keve A. (1972a): A Balaton guvat-féléi. Állattani Közlemények 59(1-4): 67-85.

KeVE A. (1972b): A Balaton sirályai. Aquila 78-79: 107-132.

KeVE A. (1973): A Balaton búvár- és vöcsökfajai, gödénye és kárókatonája. A Veszprém megyei múzeumok közleményei 12: 565-573.

Keve A. (1975): Adatok az "Iszap" (Balatonberény) madárvilágához. Somogyi Múzeumok Közleményei 2: 155-161.

Keve A. (1978): A Balaton déli partjának madárvilága. Somogyi Múzeumok Közleményei 3: 462-501.

KEVE A. (1982): A Balaton szárcsaállományának összefüggése a rendelkezésre álló táplálékkal. Állattani Közlemények 69(1-4): 119-121.

Keve A. (1983): A bukórécék jelentősége a Balaton életében. Aquila 90: 105-112.

KeVE A. \& PÁTKAI I. (1955): Magyarország és a Kárpát-medence nagysirályai. Aquila 59-62: 311-333.

Keve A. \& SchmidT E. (1963): A vízimadarak vonulásának egyidejü (synchron) kutatása. Aquila 69-70: 145-157.

KLEINER E., PÁtKAi I. \& VerTSE A. (1942): Az 1941. évi madártani Balatonkutatás főjelentése. A Magyar Biológiai Kutatóintézet Munkái 14: 95-131.

Koskimies, P. \& PÖYsÄ, H. (1991): Waterfowl point count. In: Koskimies, P. \& Väisänen, R. A. (ed). Monitoring Bird Populations. Zoological Museum-Finnish Museum of History - University of Helsinki, Helsinki. p. 41-44.

KovÁcs GY. (2005a): Bird monitoring at the southern shore of the Lake Balaton. In: POHLMEYER, K. (ed.): Extended Abstracts of the XXVIIth Congress of the International Union of Game Biologists, Hannover 2005. DSV-Verlag Hamburg. p. 391.

KovÁCs GY. (2005b): Vízimadár állományviszonyok alakulása a Balaton déli partján 20032005 között. In: Lengyel Sz., Sólymos P. \& KleIN Á. (szerk.): III. Magyar Természetvédelmi Biológiai Konferencia Program és Absztrakt kötete. Magyar Biológiai Társaság, Budapest 2005. p. 145.

KovÁcs GY. (2007a): Bird monitoring at the southern shore of Lake Balaton (Hungary) during the period 2003-2007. In: SJÖBERG, K. \& ROOKE, T. (ed.): Book of Abstracts of the International Union of Game Biologists XXVIII Congress. Uppsala 2007. p. 260.

KovÁCS GY. (2007b): Nagy területü vízimadár szinkronszámlálások a Balatonon. In: LAKATOS F. \& VARGA D. (szerk.): Erdészeti, Környezettudományi, Természetvédelmi és Vadgazdálkodási Tudományos Konferencia (EKTV-TK). 2007. december 11., Sopron. Konferencia kiadvány. p. 110-111.

KovÁCs Gy. (2008a): Dél-Balatoni Madár Monitoring. Ornis Hungarica 15-16(1): 97-98.

KovÁCs GY. (2008b): Vízimadár monitoring a Balatonon és környékén 2003-2008 között. A Magyar Madártani és Természetvédelmi Egyesület VII. Tudományos Ülése. Eötvös József Föiskola, Baja 2008. október 24-26. Programfüzet. p. 35.

KovÁCs GY. (2008c): A 2005. november 12-i balatoni vízimadár-felmérés eredményei. Magyar Vizivad Közlemények 16: 247-254.

KovÁCs Gy. (2008d): A 2006. december 16-i balatoni vízimadár-felmérés eredményei. Magyar Vizivad Közlemények 16: 255-260.

KovÁCs Gy. (2008e): A 2007. november 10-i balatoni vízimadár-felmérés eredményei. Magyar Vizivad Közlemények 16: 261-266.

KovÁCs GY. (2008f): Küszvágó csér (Sterna hirundo) előfordulások a Balaton déli partjánál, és költése az Irmapusztai-halastavakon. Natura Somogyiensis 12: 177-183. 
KovÁcs GY., WinkLER D. \& FARAGÓ S. (2011): A kárókatona fészekalj és tojásméret vizsgálata a Kis-Balatonon és a Nagyberekben. Natura Somogyiensis 19: 275-279.

Lovassy S. (1897): XIV. Szakasz. Madarak (Aves). In: ENTZG. (szerk.) A Balaton tudományos tanulmányozásának eredményei. Második kötet: A Balaton tónak és partjainak biológiája. Első rész: A Balaton faunája. A Magyar Földrajzi Társaság BalatonBizottsága. p. 220-237.

MME NOMENCLATOR BIZOTTSÁG (szerk.) (2008): Magyarország madarainak névjegyzéke. Nomenclator Avium Hungariae. Magyar Madártani és Természetvédelmi Egyesület. $278 \mathrm{p}$.

Nagy L., Vers J., Lelkes A., Vókó L., FehÉr Cs. E., Novotny Zs., Poller Z., MAGyari M. \& FEKETE Á. (2008): A vízimadár-szinkronszámlálások eredményei a Balatonon és ahhoz közeli vizes élőhelyeken 2003-2007 között. Aquila 114-115: 27-41.

PANneKoeK, J. \& STRIEN, A. V. (2001): TRIM 3 Manual. Trend and Indices for Monitoring data. Research paper no. 0102. Statistics Netherlands, Voorburg.

SCHMIDT E. (1974): A novemberi és januári réceszámlálások néhány eredménye Magyarországon I. Anas platyrhynchos. Aquila 80-81: 149-168.

SCHMIDT E. (1976): A novemberi és januári réceszámlálások néhány eredménye Magyarországon II. Anas crecca. Aquila 83: 137-141.

STERBETZ I. (1975): A vadlúdvonulás alakulása a magyarországi gyülekezőhelyeken. Aquila 82: 181-194.

SzINAIP. (1997): Status of the Mute Swan (Cygnus olor) in 1997 in Hungary [A bütykös hattyú (Cygnus olor) helyzete Magyarországon 1997-ben]. Aquila 103-104: 9-16.

SzINAI P. (1998): A bütykös hattyú helyzete a Balatonon 1997-98-ban. Füzike 32: 9-14.

TUCKER, G. M. \& HEATH, M. F. (1994): Birds in Europe: their conservation status. (BirdLife Conservation Series 3.) Cambridge, U.K.: BirdLife International. 600 p.

WeTLANDS INTERNATIONAL (2002): Waterbird Population Estimates - Third Edition. Wetlands International, Wageningen, The Netherlands.

Wetlands International (2006): Waterbird Population Estimates - Fourth Edition. Wetlands International, Wageningen, The Netherlands.

Wetlands InTERnAtional (2012a): Waterbird Population Estimates. Online database. wpe.wetlands.org (letöltés: 2012.09.11)

WeTlands International (2012b): Waterbird Population Estimates, Fifth Edition Summary Report. Wetlands International, Wageningen, The Netherlands. 24 p.

WETLANDS INTERNATIONAL \& SOVON (2011): Analysis of trends of selected waterbird populations in the African-Eurasian Waterbird Agreement Area. Wetlands International, Wageningen, The Netherlands. http://www.wetlands.org/ AfricanEurasianWaterbirdCensus/AEWAConservationStatusReview/tabid/2578/Def ault.aspx (letöltés: 2012.09.05.) 


\title{
POPULATION DYNAMICS OF WATERBIRD SPECIES ON THE SOUTHERN SHORE OF LAKE BALATON BETWEEN 2003-2008
}

\author{
Gyula Kovács
}

\author{
Summary
}

\section{INTRODUCTION}

Numerous ornithological papers have been published about the avifauna of Lake Balaton; however, due to the complexities of research in this area, only a few comprehensive studies have been published about population changes of local waterbirds. In the 1970's KEVE, in the 1980 's BANKOVICS, and in 2008 NAGY et al. summarized the status of the waterbird population on Lake Balaton.

As of the beginning of the 21 st century there was no current and detailed data available for the waterbird fauna of Lake Balaton. Thus a monitoring (South Balaton Bird Monitoring) was started in 2003 with the volunteers of South Balaton Nature Conservation Group (BirdLife Hungary). Monitoring was organised by the author of the current dissertation to systematically study the waterbird population of the southern shore and the surrounding wetlands of Lake Balaton. The main objectives of the survey were to explore the local waterbird communities and follow their population changes.

\section{MATERIAL AND METHODS}

The waterbird survey was carried out monthly at the southern shore of Lake Balaton at 18 survey plots (Map 1), on 60 observation days in a 5 year time span (2003-2008) for a total of 1048 observations. The survey method is similar as described KAUPINNEN et al. (1991), KOSKIMIES \& PÖYSÄ (1991) and FARAGÓ (1997).

Data were analysed with Microsoft Excel 2010 and PAST v. 2.12 (HAMMER et al., 2001) software. Waterbird population change analysis by linear regression was based on population change (chain) index (GREENWOOD et al., 1993). The classification of the trends was interpreted after PANNEKOEK \& VAN STRIEN (2001). To compare the seasonal average population one-way ANOVA was used. Pairwise comparison was carried out using post-hoc Tukey's HSD test.

\section{RESULTS}

According to the monthly surveys a total of 86 species from 16 families and 10 orders were observed, from which a total of 78 species from 12 families and 7 orders were waterbirds. The main taxonomic groups of the waterbird community were: Anatidae (56.3\%), Laridae $(22.8 \%)$, Rallidae (11.8\%), Phalacrocoracidae (5.8\%), Podicipedidae (1.4\%) and Sternidae (1.2\%) families (Table 4).

Based on the national and the international conservation status (IUCN Red List, SPEC categories, Bird Directive, Bonn Convention, Bern Convention) of the observed waterbird species the southern shore of Lake Balaton proved to be a highly important bird habitat (Table 5). The abundance of the Great Cormorant, White-fronted Goose, Greylag Goose and the Goldeneye population of the Lake Balaton fulfilled the Ramsar criteria according to which the population reached the $1 \%$ threshold. 
Population sizes of the 16 common waterbird species were estimated as (Figure 49):

- Population sizes of the Little Egret and the Great Egret were under 100 individuals.

- Population size was estimated to be in the 100-1000 range for the species of: Great Crested Grebe, Mute Swan, Greylag Goose, Northern Shoveler, Tufted Duck, Mew Gull, Yellow-legged/Caspian Gull and Common Tern.

- For the the Great Cormorant, Mallard, Pochard, Goldeneye, Coot and Black-headed Gull population sizes were ranged over 1000 individuals.

According to the earlier and recently published references the populations of Little Egret, Great Egret, Northern Shoveler, Yellow-legged/Caspian Gull and Common Tern are concentrated mostly at the southern shore of Lake Balaton; therefore, their population sizes in this region serve as adequate reference for the rest of the Balaton. In case of the other less localised bird species observational data from the southern shore of the lake can offer suitable estimation for the entire area of Lake Balaton.

Analysing the short term (2003-2008) population changes of the common waterbird species (Table 6):

- There was a strong increase observed in case of the Great Crested Grebe, Coot and Great Cormorant.

- A strong decrease was observed in the populations of Great Egret, Yellowlegged/Caspian Gull and Common Tern.

- There were no significant changes detected in population trends for the species of the Little Egret, Mute Swan, Greylag Goose, Mallard, Northern Shoveler, Pochard, Tufted Duck, Goldeneye, Black-headed Gull and Mew Gull.

Species that showed changes in population trends in all cases differed from each other at the national level (Table 6). Similarly to the southern shore of Lake Balaton population trends of the Mute Swan, Mallard, Northern Shoveler, Pochard, Tufted Duck and the Goldeneye were shown to be uncertain.

Population trends of the Great Crested Grebe and Coot were directionally similar to international trends (AEWA) (Table 7); however, tendency of the trends lagged behind of those observed at the southern shore of Lake Balaton. Population trends of the Little Egret and Goldeneye were also deemed uncertain. In respect of other species no similarity was found in population trends.

Based on the above results, strong increase in the population of the Great Cormorant, the Great Crested Grebe and the Coot (in the case of the latter two species, at an international level only the rate of growth); as well as, a strong decrease in the population of the Great Egret were defined as a typical local trend of the southern shore of Lake Balaton.

Analyses of short term (2003-2008) population changes of such scarce waterbird species as the Grey Heron and the Herring Gull of the southern shore of Lake Balaton showed a strong decreasing trend, while the opposite trend (strong increase) was observed in case of the Black-throated Loon (Table 2).

In terms of phenology of the following observations were made:

- The period between early autumn and winter is the most important as most of the bird species can be observed at this time.

- The Great Crested Grebe, the Great Cormorant, the Mute Swan, the Mallard, the Pochard, the Black-headed Gull and the Yellow-legged/Caspian Gull were present throughout the entire year.

- The maximum population sizes (MPSs) of Great Crested Grebe were in April and October. MPSs of Great Cormorant and Mallard were in December. MPS of Mute Swan was in September. MPSs of Pochard and Tufted Duck were in November and March. MPS of Goldeneye was in January and March. MPS of Coot was in October 
and November. MPS of Black-headed Gull was in September and January. MPS of Mew Gull was in December and January. MPS of Yellow-legged/Caspian Gull was in August and MPS of Common Tern was in July and August. 